\title{
Archaeometry in the Cultural Heritage Studies and Art (Definitions, Future Trends and Challenges)
}

\author{
Mehdi Razani*1, Fateme Sehati ${ }^{2}$, Masoud Bagherzadeh Kasiri ${ }^{3}$ \\ 1. Assistant Professor, Faculty of Cultural Materials Conservation, Tabriz Islamic Art University, Tabriz, \\ IRAN \\ 2 .Lecturer, Faculty of Cultural Material Conservation, Tabriz Islamic Art University, Tabriz, IRAN \\ 3. Associate Professor; Faculty of Cultural Materials Conservation, Tabriz Islamic Art University, \\ Tabriz, IRAN
}

Received: $5 / 10 / 2020$

Accepted: $10 / 09 / 2020$

\begin{abstract}
Understanding and investigation of the principles, fundamentals, and the actions during the last century; following the emergence of the concept of "archaeometry" or "archaeological science", that have encompassed the areas of cultural heritage, has have become a must for understanding the nature of scientific trends in archaeometry. Therefore, it is important to clarify the main definitions as the most important fundamental principles in conceptualization to create a common language. The purpose of this study was to investigate the origins of archaeometry by studying the approaches, areas, and boundaries of the related studies, to achieve the principles and basis of this scientific discipline. In Europe, archaeometric activities have been developed over the last century, with a focus on the topics and issues raised in the form of various interdisciplinary research approaches, and today, much of the research in this field of cultural heritage science is being conducted in an interdisciplinary approach, due to the variety of topics. According to a historical study of this interdisciplinary area of science, it can be said that archaeometry in the West has an archaeological origin and is related to the natural sciences. But in Iran, archaeometry was officially initiated under the domain of restoration of historical objects at the universities, began with the establishment of laboratories dedicated for archaeometrical studies in museums and research centers, and continued recently as an independent university discipline. Today, the most important axis of this scientific discipline includes: Characterization, Dating, Provenance, Authentication, Identification the objects application, Reconstruction of the ancient technologies, Science of conservation and restoration, Prospection \& Remote sensing methods in archaeometry, Bioarchaeology, Geoarchaeology \& Paleoclimatology, and Cyber-archaeology. The results of the investigations and studies realized in this research showed that due to the interdisciplinary nature of archaeometry in a discourse and research approach, it could not have a theoretical foundation. Meanwhile, understanding and adhering to the principles and foundations of the methodology of this interdisciplinary research approach in relation to the other sciences must be admitted. As if some rules and principles, such as the ethics in archaeometry, as a basic concern, have shaped the limitations and developed the archaeological methodological approach.
\end{abstract}

Keywords: Archaeometry, Interdisciplinary, Principles, Cultural Heritage Sciences

*Corresponding Author: Email: m.razani@tabriziau.ac.ir

Copyright@ 2021, the Authors / This open-access article is published under the terms of the Creative Commons Attribution-NonCommercial 4.0 International License which permits Share (copy and redistribute the material in any medium or format) and Adapt (remix, transform, and build upon the material) under the Attribution-

.NonCommercial terms 


\section{Introduction}

The development and deepening of the vast area of sciences related to cultural heritage in the form of recognition of different aspects of human life based on the cultural relics and works that remained from the distant past to the contemporary art require the cooperation of many experts in various scientific and technical fields and majors. In the recent century, mostly by using physical science and engineering, some studies have been conducted about the cultural heritage relics, museum artifacts, and archaeological discoveries, and since 1958, such interdisciplinary studies have been known as "Archaeometry" [1]. Archaeometry, as an integrated research approach, has dealt with the physical, chemical, and mathematical analysis of the archaeological finding and materials using the scientific method, and although initially it was limited to the research areas such as the dating, provenance, production methods, distribution, and the way to use the artifacts, todays, with the advancements and developments in various sciences and access to the modern technologies, it has been able to achieve a more significant position among other sciences, whose result is the growing scope of research in this research approach $[2,3]$. Archaeometry has been established as a new trend since 2012 based on the needs of the scientific community, especially in the field of cultural heritage sciences. Since foundations of this imported discipline have not progressed in the right direction since its entry, it is needed to, besides paying attention to the preparation of the research infrastructure regarding technical and engineering sciences (equipment, tools, etc.), on the other side of this integrated approach, make the broad dimensions of archaeometry studies in the cultural heritage and art sciences better known to the researchers and professionals, to localize it [5]. Recognition of these areas and fields regarding the integrated nature of this approach would help more experts from physical science fields try their hand in responding to the questions related to archaeology and cultural heritage. Therefore, regarding the lesser-known nature of this integrated approach, the introduction of the most important research fields of archaeometry is the main objective of the current study.

\section{Discussion}

Some of the most dominant and debated topics in the field of archaeological studies, which have also formed the related literature of the current study, are the following (Figure 1):

\section{Dating and Dating Methods}

Dating is a temporal soring of the data and an essential prologue to understanding the sequence and stages of past events [19], which is among the main study topics in archaeometry. The main criterion of dating the measurable materials is the tangible and gradual changes due to environmental and natural phenomena. If all the factors effective on a change are measurable and their speed is known, absolute dating (chronometric dating) will be possible. Nevertheless, if only the reason for these changes is known, or all the factors effective on a change speed cannot be measured precisely, the time sequence and relative ancientness of an event can be determined only through contrastive and comparative studies.

\section{The Morphology and Origin}

The morphological studies can be considered the use of physicochemical methods and the methods of recognition and investigation of the morphology and structure and the physical and chemical characteristics of the materials. In terms of antiquities, the ratio of organic and mineral components, elements, and compounds can be studied. Nevertheless, morphology can be considered one of the main fields of study in archaeology [27, 28], which is highly efficient in material origin and raw sources with appropriate statistical descriptions [6].

The origin is another important area in archaeology, related to the two words "Provenance" (the beginning of something's existence; something's origin) and "Provenience" (the place of discovery and the place of origin, and the archaeological context). It should be considered that a wide range of human activities such as trade, transaction, distribution, immigration, and group migration can be the cause of the movement of the artifacts from their place of production to the place of discovery [32-33]. 


\begin{abstract}
Authenticity
Authenticity can mean original, first-hand (as opposed to counterfeit), real, true, and original (as opposed to fictitious). On the contrary, we face unoriginal artifacts based on the intention behind their presentation; we can face various definitions such as fake, counterfeit, imitation, duplicate, copy, and moulage. In other words, it can be said that what is not original, whose creation is not original and does not have at least one of the originality criteria (such as the originality of the main material, form, originality in pattern and inscription, originality in style, historical originality, and originality in attribution) [42]. Also, authenticity is one of the most important determiners in terms of measures related to protecting the heritage.
\end{abstract}

\title{
Identification of the Use of the Objects and Reconstruction of the Ancient Technologies
}

Investigating the way of use of objects in the past and reconstructing their production technologies are among the most important areas of archaeometry [51]. It had been previously manifested in the form of two other trends: experimental archaeology and, somehow, protection and restoration of monuments. To better clarify each topic in these two fields, some concepts have to be noted.

In archaeometric studies, technology research pursues several topics. First, evaluation of the technology itself, second, how the products are produced, and third, the information about the materials used in an area, in addition to conditions and methods of production, processing, and evolution of the related technology.

\section{Science of Protection of Cultural Relics}

This science includes physiochemical studies about the demolition processes and the development of new medical methods related to the protection and restoration, which is discussed under the archaeometry discipline [6] [62, 64]. This field itself includes several main sub-disciplines, which generally include: Study on the mechanism of degradation and erosion of various materials over time; study of the pathology of natural and historical monuments, study of the functional characteristics and intrinsic properties of historical materials and their relationship with restoration materials and protection methods, study of modern methods of protection and restoration and materials used and finally, study of interactions between modern and ancient materials, and the results of analyses from archaeological experiments [63].

\section{Prospecting and Remote Sensing}

The methods of excavation and study by modern archaeologists have made significant advances over the traditional practice of the past. Today, with the support of prospecting methods from the archaeologists' measures in the field of excavation, the costs have economized on the one hand, and on the other hand, it has made the excavations more targeted and focused on the available remains. The most important functional methods in this field of archaeometry can be classified under two main axes: remote sensing and prospecting by using geophysical methods. Remote sensing includes a wide range of scientific methods to study ground and underground surfaces at close and far distances, which act with outcomes such as imaging in various ways and obtaining information from archaeological sites without practical archaeological excavations.

The geophysical prospecting discoveries are associated with aerial archeology and laser scanning methods, effective and non-destructive methods for restoration, and understanding and following up archaeological research [66]. This field of research is contrasting and properly implementing the experimental geophysical method in the archaeological sites, which deals with the interpretation and modeling of underground surface structures by analyzing the physical changes of some points on the ground. It has been developed to record the physical traits of the parts close to the ground surface in a way that by measuring some specific points on the ground, it would be possible to understand some of the characteristics and changes that have occurred in the physical conditions of the underground and the differences in different places. The measurement and determination of these differences (anomalies) in different points can be done by changing the measured values in one place compared to its surrounding environment. Then, by special processing of the data, and ultimately, preparation of the related maps, a mass with significant physical differences from its surroundings can be detected below the ground surface [67-68-69]. 


\section{Bioarchaeology}

Today, bioarchaeology is still used in England and other European countries to study non-human remains, including animal, plant and in general, all biological and organic materials obtained from ancient sites (archeology, stool analysis, etc.), however, in the United States, this term, which is considered as an all-American evolution, is only used for human remains [76, 80-81]. As an academic interdisciplinary research area, bioarchaeology acts as a connecting bridge between sciences such as biology, medicine, anthropology, and social sciences through studying the human bone remains. The cornerstone of bioarchaeology is the interaction between culture and biology. Today, these studies have stepped in the path of coherent and scientific research at the demographic level (genetic kinship, diet, disease, lifestyle of ancient peoples, biological and cultural evolution) [82].

\section{Geoarchaeology and Paleontology}

The term "Geoarchaeology" was first introduced in the early 1970s, and now it has a noticeable history, connected with other disciplines such as geology, geography, environment, archaeology. It refers to geological and archaeological approaches that provide information on past landscapes, ancient climates, plants, and animals. In addition, geoarchaeology is a fast-growing interdisciplinary major in which archaeologists and geomorphologists try to use both sciences to solve mutually-interested problems. It includes the use of the principles of morphology, sedimentation, isotope geochemistry, and petrology. Among the main usages of this field of study is the restoration of the ancient time on the local and regional scale and the ancient climate zones in different parts of the world. In paleoclimatology or the study of previous climates, the scientists use what is known as proxy data to restore past weather conditions. These proxy data are the physical characteristics of the environment. The paleoclimatologists gather the proxy data from the natural recorders of climate change such as tree rings, ice cores, fossil pollens, ocean sediments, corals, and historical data [6].

\section{Cyber-archaeology}

Cyber-archaeology is a combined and linked set complex of archaeology, computer science, engineering, and natural sciences, and provides 21-century solutions to protect the past and preserve it for the future. It includes measures in the form of digital reconstruction in the virtual environment [93]. In simple terms, it is possible to summarize the sub-categories of the field of cyber archeology in 1) development of statistical and information software related to archaeological sciences, 2) creation and construction of databases, 3) topics related to digital documentation of historical monuments and buildings in the form of various methods of photography and illustration [95].

\section{Conclusion}

As is known, archaeometry is an interdisciplinary research area concerning the questions and problems about cultural heritage, art, and archaeology. Different scientific and technical fields, which are in line with their development and growth, deal with the scientific research related to the unknown ancient subjects, all in an interconnected unity following the study of issues related to the life of ancient humans and before. Any of these related disciplines is developing independently. It seems among the important challenges in the development of archaeometry; the archaeologists must seriously follow these:

- Investment in cultural heritage studies for archaeological research

- Creation of discourse between archeology and archaeometry

- Archaeometry training courses

- Creation and completion of the archaeometry databases

- Promotion of the archaeometry publications

Scientific disciplines such as pollenology, archaeo-osteology, archaeo-zoology, archaeobotany, archaeometallurgy, and archaeo-astronomy can be easily subdivided into several archaeological studies; and are suggestions that the researchers can evaluate in the future. It seems like that in the continuance of this research approach, the development of archeological ethics can be the next step in its development way. 


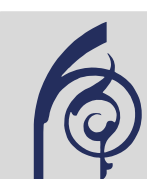

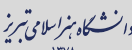

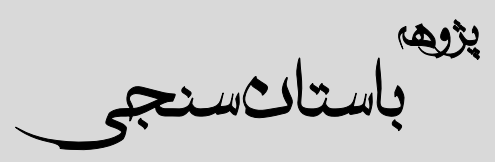

URL: http://jra-tabriziau.ir/

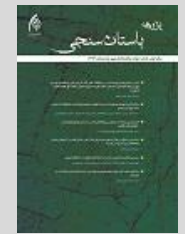

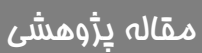

\title{
باستان سنجى در مطالعات ميراث فرهنكى و هنر

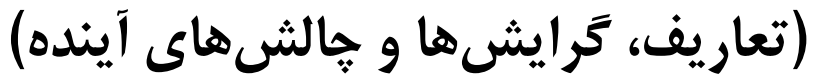

\author{
مهدى رازانى "*، فاطمه صحتى "، مسعود باقرزاده كثيرى

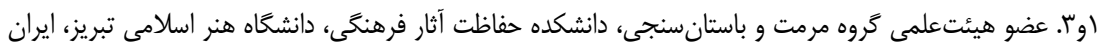

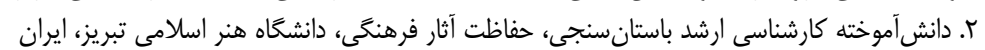

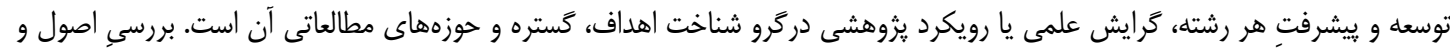

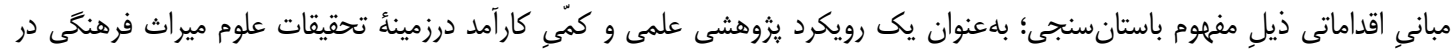

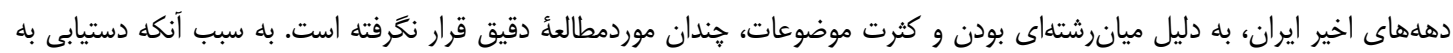

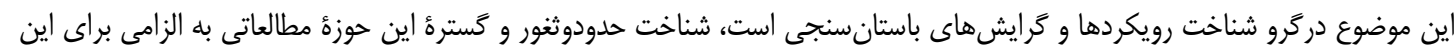

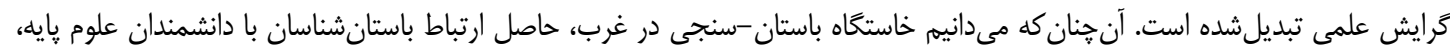

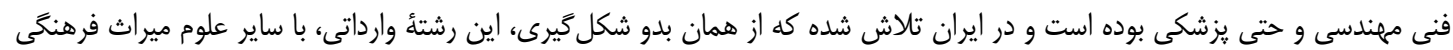

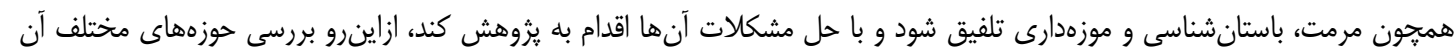

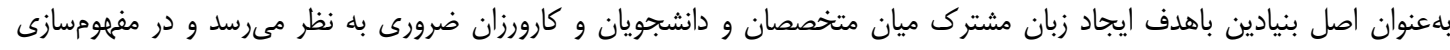

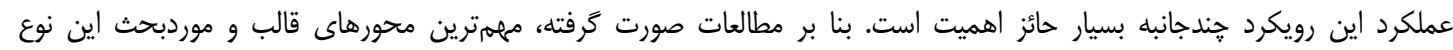

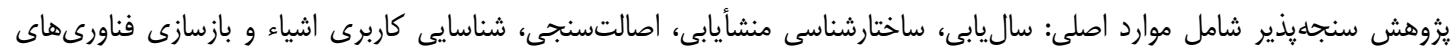

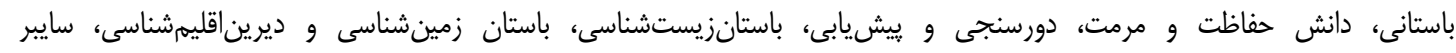

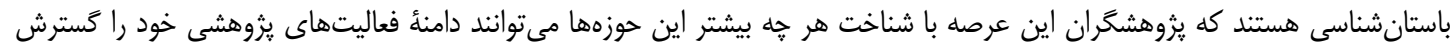

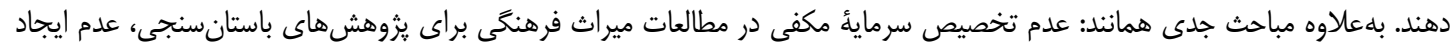

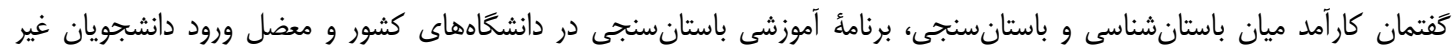

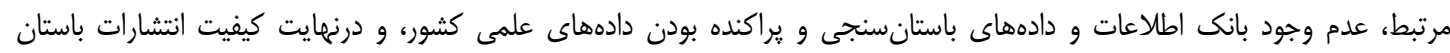

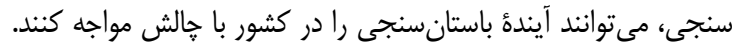

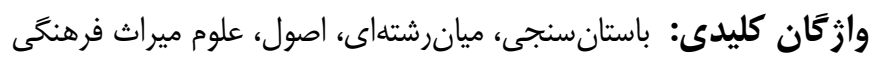

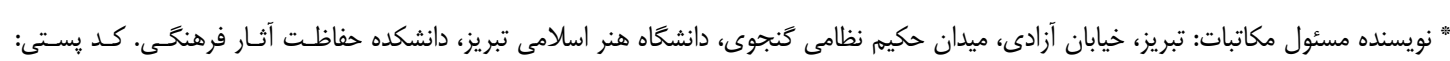

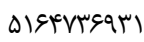

m.razani@tabriziau.ac.ir :حست الكترونيكى

C) حق نشر متعلق به نويسنده(كان) است و نويسنده تحت مجوز Creative Commons Attribution License به مجله اجازه مى دهد مقاله خاب شده

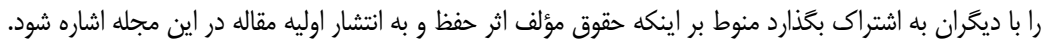


يزوهشكران و متخصصان شناخته شـدهتـر شـود [5].

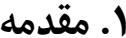

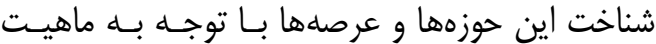
تلفيقى اين رويكرد، كمك خواهد كرد كه متخصصان بيشترى از حوزههاى مختلف علوم ريايه، توانايى خـود رودي

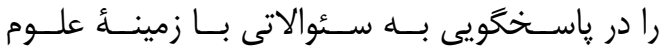
باستانشناسى و ميراث فرهنگى محك بزنند؛ بنابراين با توجه به ماهيـت كمتـر شناختهشـده ايسن رويكـرد تلفيقى، معرفى مهمترين حوزههاى تحقيقاتى رويكـرد يزوهشى باستانسنجى موضوع اصلى اين مقاله است. اين مقاله در راستاى تحقيقات و حوزههـاى باسـتان-

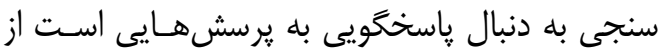
قبيل اين كه تعاريف اصلى، مفاهيه، محسـدوديتهــا و

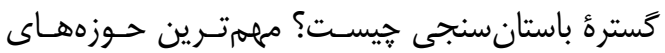
يزوهشى فعال در زمينهُ باستانسنجى كدام هستند؟ و همجنين ساير يرسش هايى كه حول ايـن موضـوعات به رشتهٔ تحرير درآمدهاند.

\section{ז. تعارف و مفاهيم باستان سنجى}

باستان سنجى از تركيب دو وازثٔ يونانى archaeos- به معناى كهن و باستانى و - metron به معناى سـانجيه

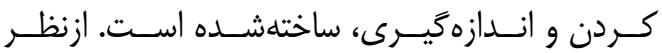

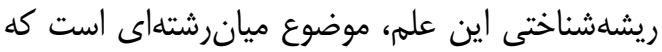

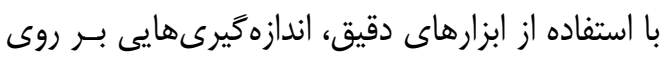

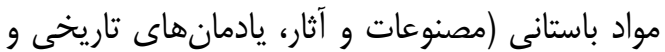
بقاياى محيطهاى كذنشته) براى تعيين يـارامترى كـهـ

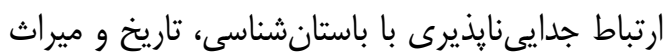

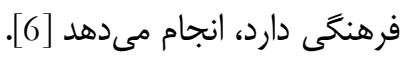
باستانسنجى نخستين بار در سال 19ه^ ميلادى بـهـ

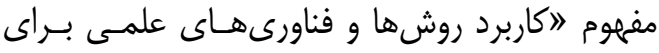

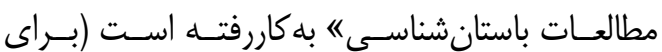

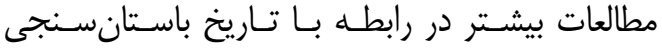

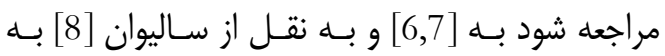

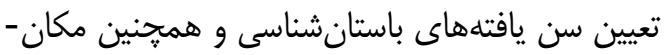

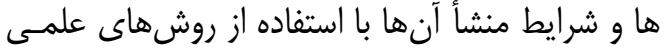

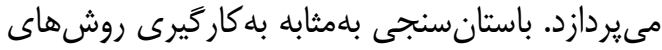

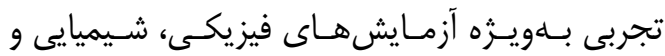

توسعه و عمقبخشى به حوزه وسيع علـوم مــتبط بـاــا

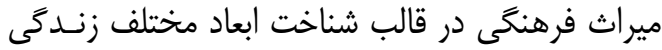

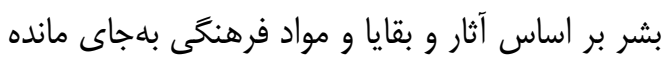

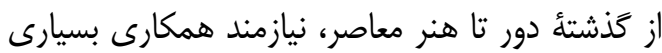

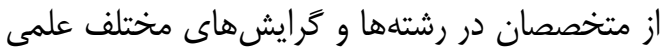

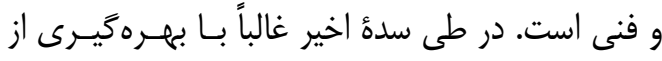

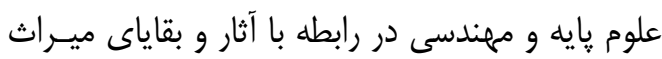
فرهنگَى، آثـار مـوزماى و كشـفيات باستانشناسى

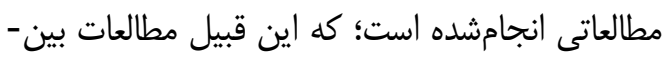

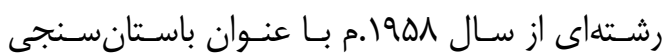

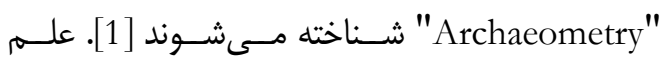
باستانسنجى بلعنوان يك رويكرد يزوهشى تلفيقى،

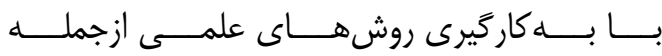

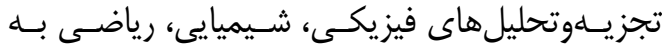

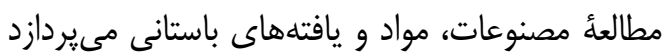

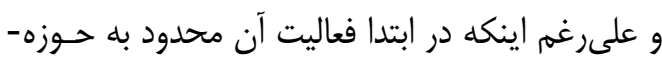

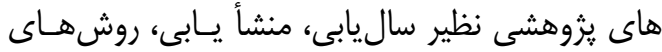

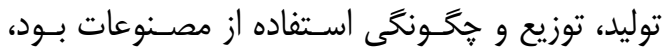

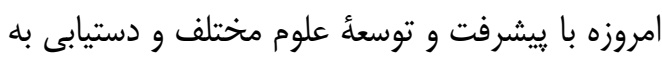
فناورى هاى نوين توانسته به جايخـاهى نامحـدودتر از

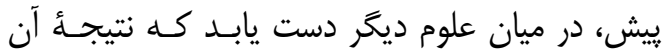

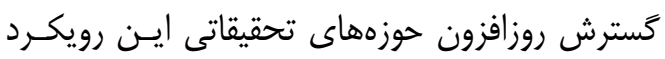

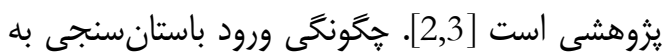

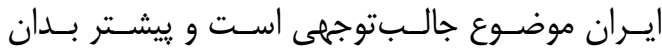

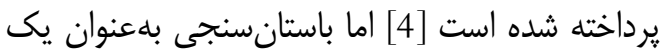

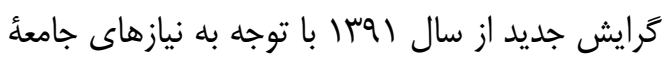

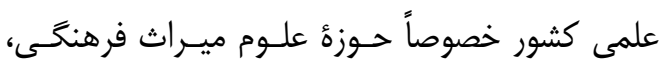

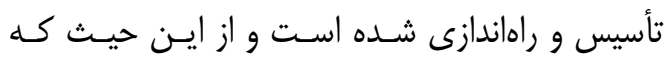

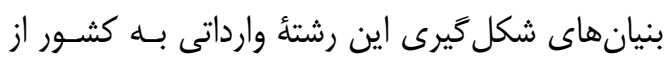
بدو ورود هندان در مسير صحيحى ييش نرفتـه، نيـاز

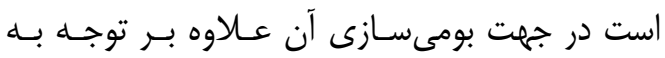
فراهمسازى زيرساختهاى يخوهشى در حـوزهُ علـوم

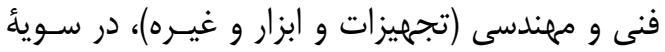
ديخًر اين رويكرد تلفيقى، ابعاد گسترده حوزه مطالعات

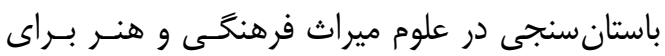


را در بر گيرد. برخى مفاهيم باستانسـنجى موجـود در

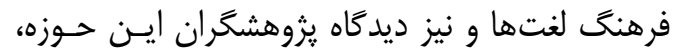
در جدول ا آمده است. اين تعاريف نشان مىدهند كه لهم

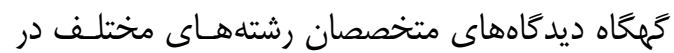

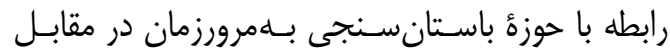
يكديخر قرار مى گيرند.
رياضيات، براى تجزيهوتحليل مـواد باسـتانشـناختى، تعيين قدمت و فناورى ساخت آنها است ؛ اما شواهد و تحقيقاتى كه در زمينههاى مختلف باستانشناسى و

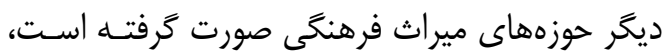

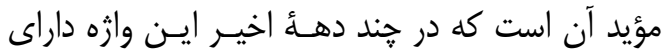
مفاهيم گستردهترى شده است و با توجه به ييشـرفت

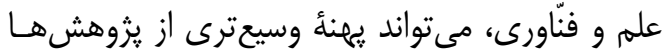

جدول (: تعاريف و مفاهيه باستانسنجى

Table 1: Definitions and concepts of Archaeometry

\begin{tabular}{|c|c|}
\hline منبع & مفهوم \\
\hline $\begin{array}{c}\text { Merriam } \\
\text { Webster/1958[9] }\end{array}$ & كاربرد روشها و فناورىهاى علمى براى مطالعات باستانشناسى. \\
\hline Ah-Dictionary[10] & 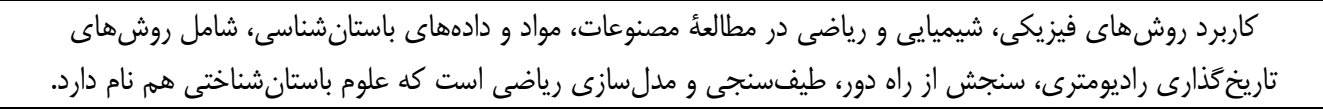 \\
\hline $\begin{array}{l}\text { Collins- } \\
\text { dictionary1968[11] }\end{array}$ & 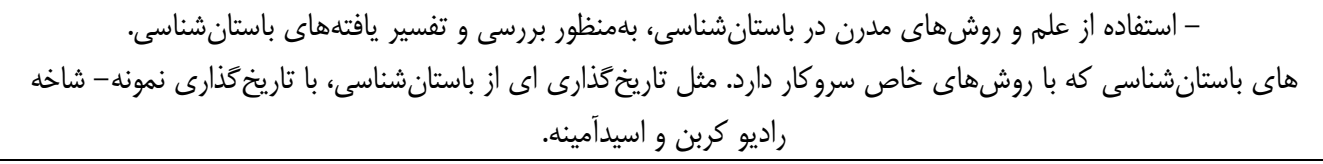 \\
\hline Sullivan 1981 [8] & تعيين سن يافتههاى باستان شناسى و همجنين تعيين مكان و شرايط منشأ آنها با استفاده از روشهاى علمى. \\
\hline Ehrenreich 1995 [12] & جدايىنايذيرى باستانسنجى از باستانشناسى و تأكيد بر وجود نواقصى در تعريف باستانسنجى از ديدگًاه برخى باستانشناسان. \\
\hline Stern $2001[3]$ & 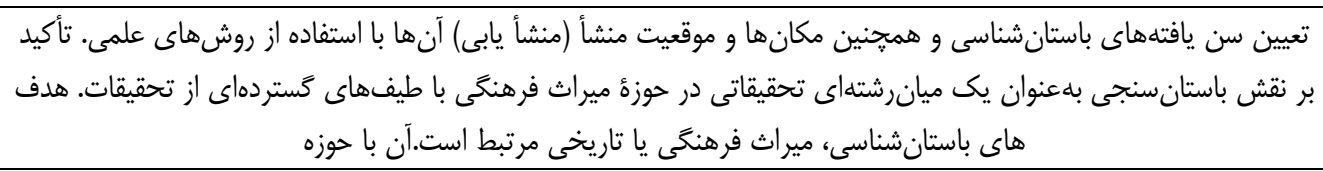 \\
\hline Tite 2004 [2] & 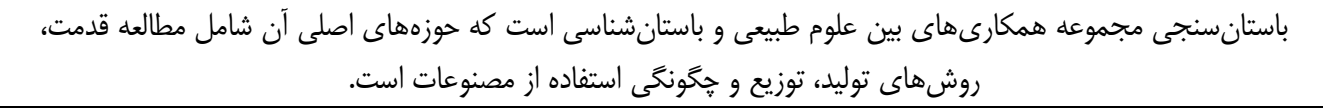 \\
\hline $\begin{array}{l}\text { Martini \& Piacentini } \\
\qquad 2004[13]\end{array}$ & ميان باستانسنجى و حوزه ميراث فرهنگى ارتباط وجود دارد. \\
\hline Jones $2004[14]$ & 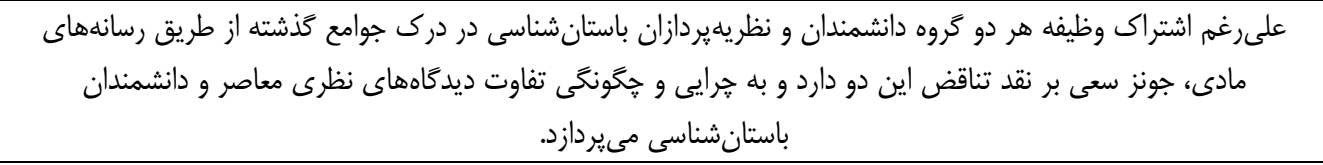 \\
\hline $\begin{array}{l}\text { Oxford Dictionary of } \\
\text { Archaeology } 2008 \\
{[15]}\end{array}$ & 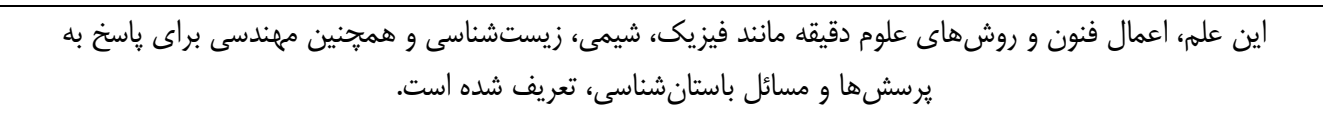 \\
\hline $\begin{array}{l}\text { Encyclopedia of } \\
\text { Global Archaeology } \\
\qquad 16]\end{array}$ & 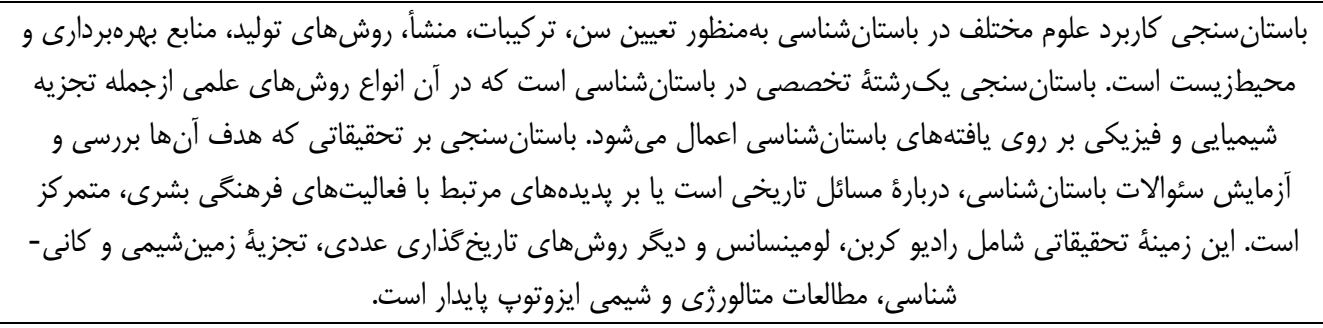 \\
\hline Artioli 2010 [17] & 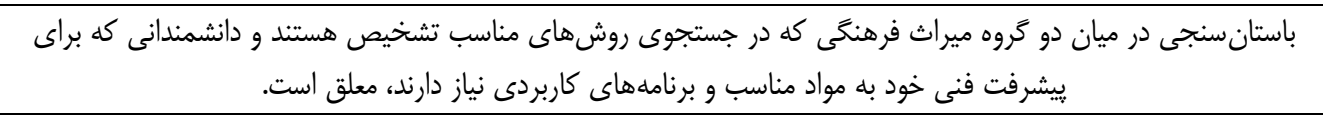 \\
\hline $\begin{array}{l}\text { Martinón-Torres \& } \\
\text { Killick } 2015 \text { [18] }\end{array}$ & 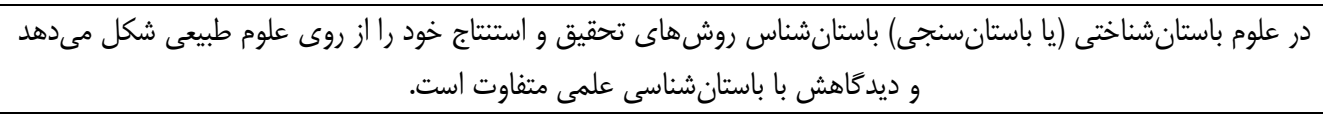 \\
\hline
\end{tabular}


مطالعاتى را شكل دادهاند، شـامل مـوارد اصـلى ذيـل هستند (شكل (). لازم به ذكر است در موارد بسيارى

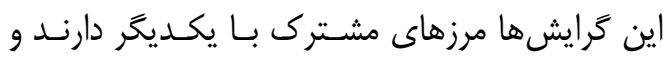

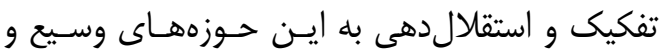
درهمتنيده دانشهايى كه مىتوانتــد درزمينـه ميـراث

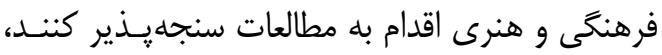

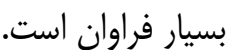

". تَر ايشهاي باستانسنجى

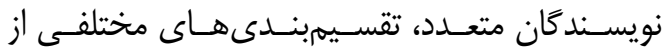

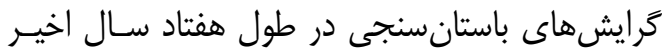

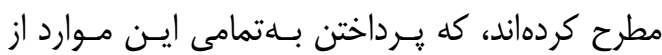

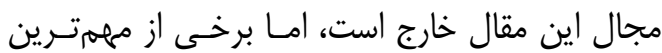

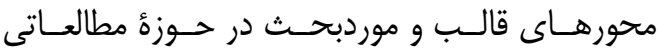
باستانسنجى كه بخشى از ادبيات يزوهشى اين كَونــ

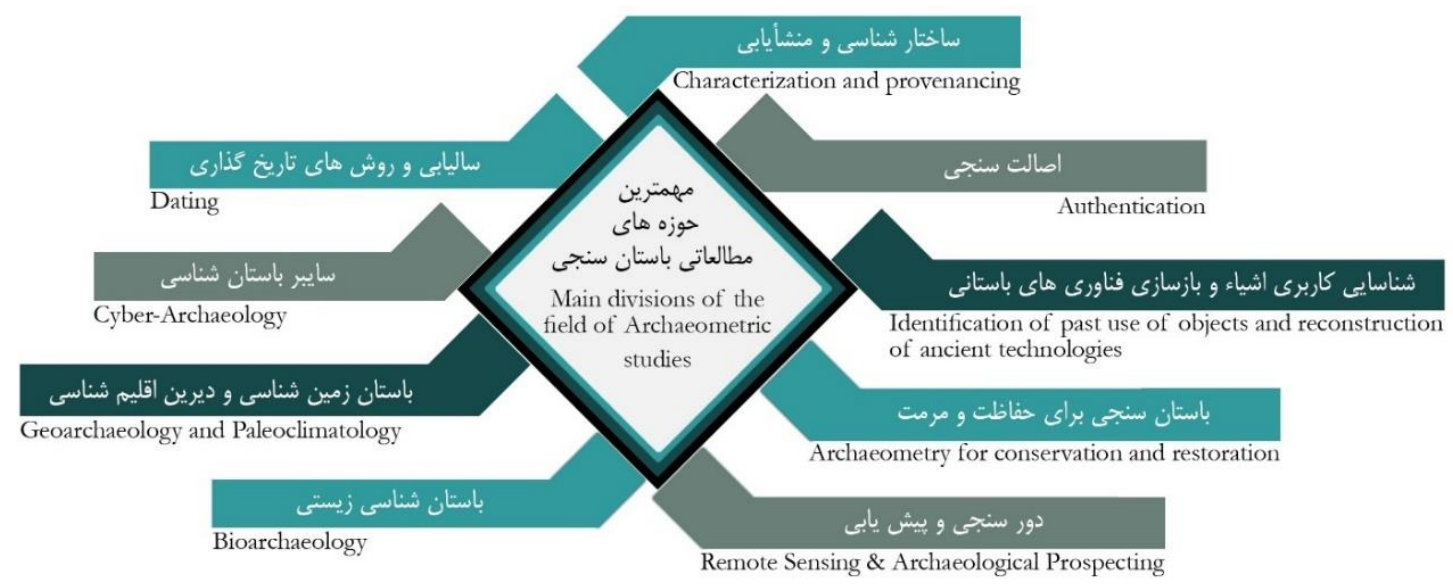

شكل (: مهرترين خرايشهاى حوزه مطالعات باستانسنجى

Fig 1: Main divisions of the field of archaeometric studies

روند ثابت رخ مىدهد، اطلاق مىشود. ديخر ايسن كـه سنيابى در حوزهٔ زمينشناسى به معناى تعيـين سـن فئن

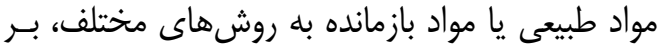

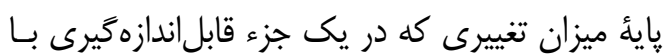
روند ثابت رخ مىدهد، تعريفشده است.2 اما نخستين بار زمين شناسان روش تاريخحـــارى را، بـراى تعيـين

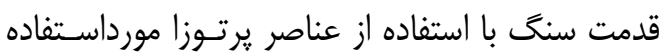
قراردادند كـه در ادامـه، در تحقيقـات باستانشناسـى موردتوجه قرار كرفت [20]. بلهنظور مطالعة كذشته، تعيين دقيق اينكه يـك بـ بـازه

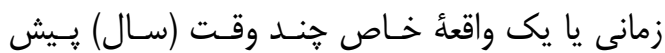

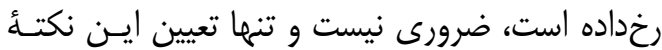

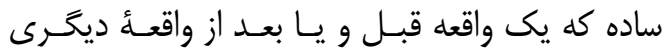
رخداده است، به بسيارى از سئوالات طرحشده، ياستخ خواهد داد. مرتبسازى توالى يافتهها و دادهها، ذخاير،

\section{ا I-r. حوزه مطالعاتى ساليابى و روش هاى} تاريخ كَارى سال يابى يا سنيابى (1 Dating)، مرتبسازى زمـانى دادها و ييشدرآمدى ضــرورى بـراى درك تـوالى و و

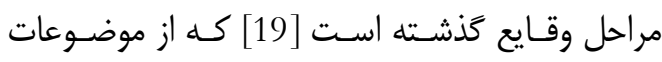

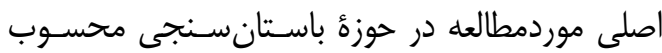
مى شود. با توجه به روش و نوع مـواد، محسدودههـاى

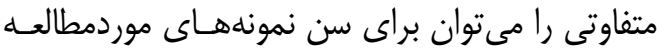

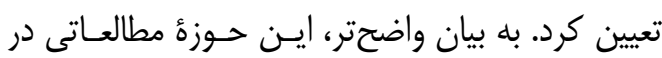
فرهنگ وازثًان مصوب فرهنگستان به دو معنا تعبيـر

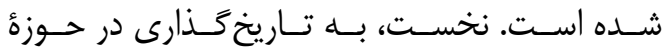
باستانشناسى كه به تعيين سن مواد طبيعى يا تعيـين

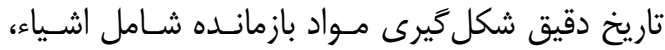

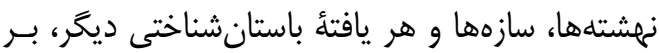

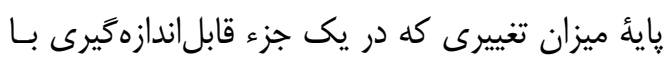


تقويمى نيز ياد مىشود. روش كار آن نيز بر اساس

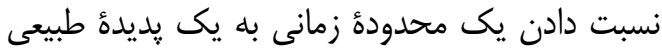
است. در اين روش، اغلب نيازى به مطابقت و تفسير سن به كمك ديخر روشها نيست (بهاستثناء راديو كربن ז1/) [19, 22-24. از جمله برخى از انواع روشهاى ساليابى نسبى مىتوان به: جينه شناسى، گونه شناسى، ترتيب سرى بندى مصنوعات، تاريخ كذارى متقابل، تجزيه و تحليل صيقل و جلا و زنغار و همجنين در روشهاى ساليابى مطلق مىتوان به

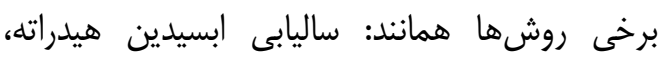
ساليابى يتاسيه آرگون، ساليابى راديوكربن، ساليابى رئ

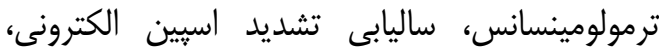
ساليابى رد شكافت هستهاى، روشهایى دين ديرين

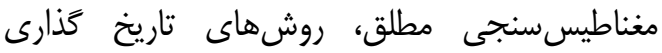

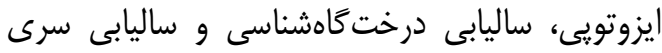

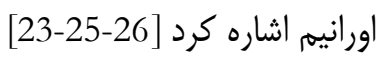
معيار اصلى براى تعيين تاريخ كذارى در دراد مواد مورداندازهگيرى، تغييرات محسوس و تدريجى مواد در طى زمان، در اثر يديدههاى زيستمحيطى و طبيعى مونى

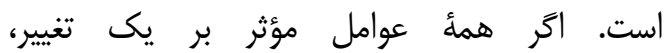
قابلاندازهگيرى و سرعت آن معلوم باشد، امكان انجام دادن ساليابى مطلق (ساليابى كرونومترى) وجود دارد؛ اما ار فقط دليل اين تغييرات شناختهشده باشد يا اخر همةٔ عوامل مؤثر بر سرعت يك تغيير را نتوان بهطور دقيق اندازهيرى كرد، فقط مىتوان بلوسيل؛ بررسىهاى مقايسهاى و تطبيقى، توالى زمانى و و

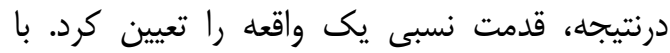

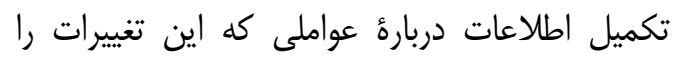
تحت تأثير قرار مىدهند، مىتوان ساليابى دقيقترى ارائه كرد. زمان آغاز تغيير در يك ماديك ماده بلهنوان ساعت صفر در نظر گرفته مىشود. اين زمان براى هر روش ساليابى به يديدهاى كه با اندازهگيرى آن

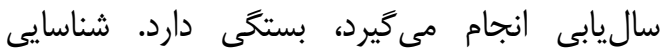
ساعتهاى طبيعى در مواد با كشف اثر يرتوزايى

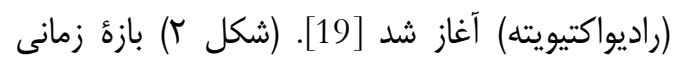
براى مهمترين روشهاى ساليابى و نيز (جدول r)
جوامع و وقايع سبب خواهد شد تا بازشـناختى نسـبت به كذشته، به دست آيد، بلدون دانستن اين نكتـه كـه هر مرحله جند سال به طول انجاميده و يا جنــد سـال

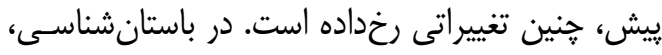
اين تفكر كه لايههاى باستانشناسى و يافتههـاى لئى آن نسبت به واقعهُ ديخرى قديمىتر و يا جديـدتر اسـت، لهـ اساس و يايئ تاريخ گذارى نسـبى (Relative dating) است. بااين حال، نكتئ مرهم در مطالعات مربوط به مواد باستانى، تعيين سن مطلق و يا كامل وقايع مختلـف و يا قسمتهايى از يك توالى است كه در ايـن صـورت نياز به روش هاى تـاريخ خَذارى مطلـق ( Absolute

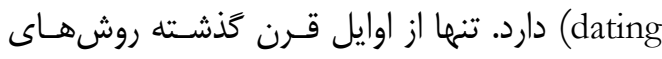
تاريخ گذارى مطلق توسـط دانشـمندان علـوم طبيعىى براى تعيين سـن مـواد ارائهشــــاند و درزمينــُ علـوم مرتبط با ميراث فرهنحَى، باستانسـنجى را متحـول ساخته|ند [21].

الف) ساليابى نسبى: كاربرد اين روش به دليل

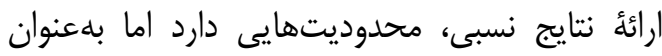

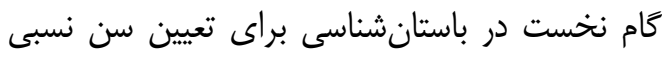

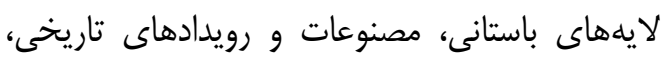
مورداستفاده قرار مى گيرد [19] كاهى ساليابى باليات استفاده از تغييرات شيميايى (تأثير عوامل محيطى ماهى

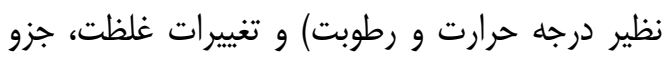
دستهبندى نسبى هستند. در اين زمينه، نمودارها و ورات

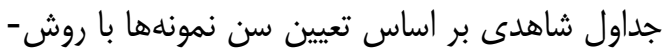

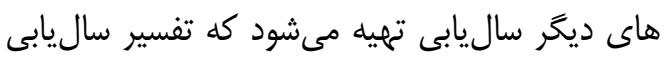

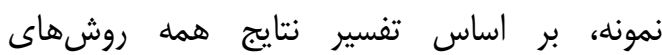
مورداستفاده در تعيين قدمت موجود در اين جداول صورت مى گيرد و بدون اين تفسير، تنها مىتوان تقدم

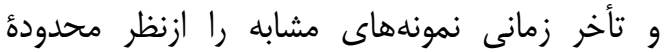
مكانى مشخص كرد [21,22]. ب) ساليابى مطلق: ساليابى مطلق، روش مارد تاريخ كذارى دقيق محسوب مىشود كه شامل اندازه-

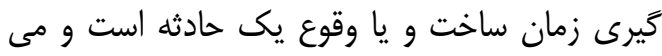

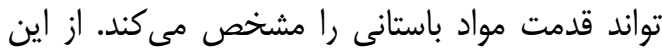

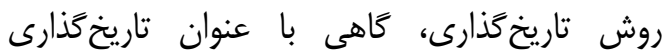


فنّاورى، به مبحث ساخت ڤايڤاه دادههاى مرتبط،

به كارگيرى روشهاى مختلف ساليابى بر روى مواد

باستانى و كاهنگارى محوطههاى باستانى، و ولهم

سنجى (Calibration) سامانهها و دستخاهها و روش -

ها يرداختهشده است.
نشاندهندة برخى روشهاى ساليابى در ارتباط با مواد مختلف است. بررسى هفتاد سال، تحقيقات

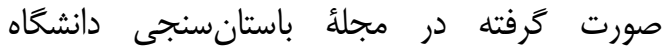

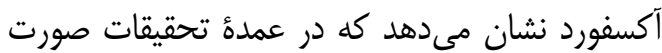

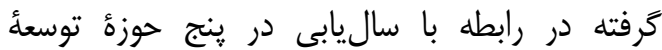

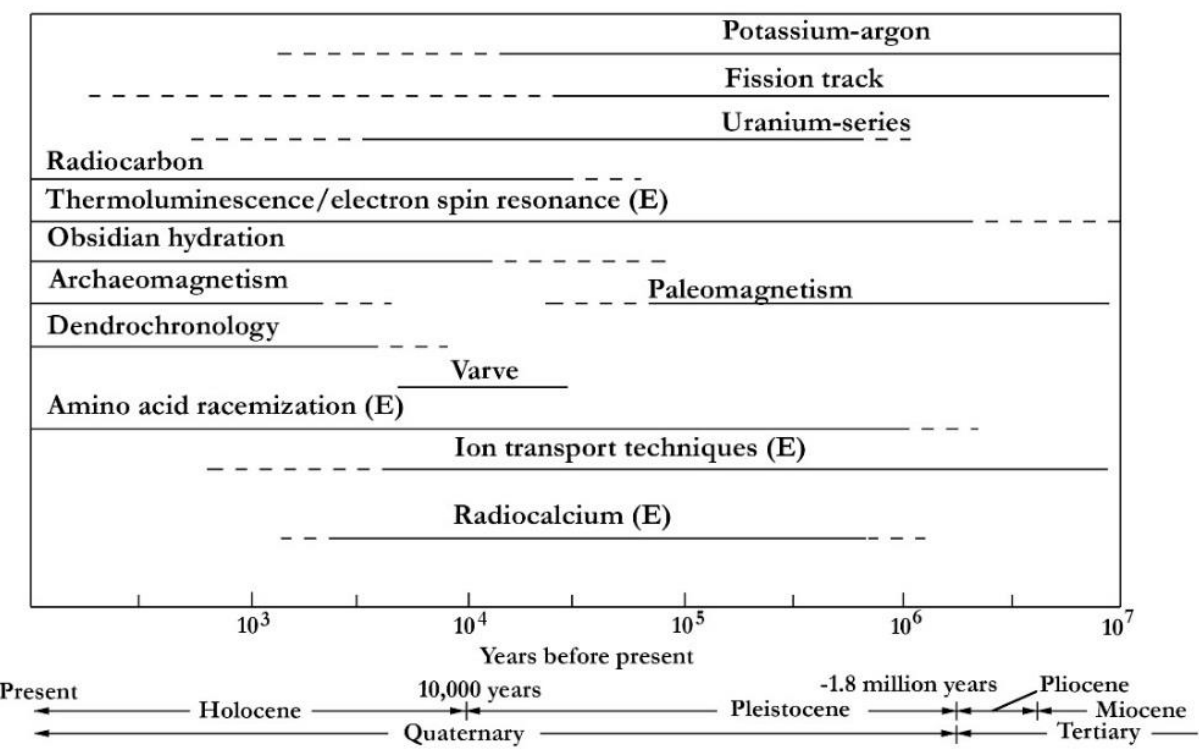

شكل r: محدودة سنى برخى روشهاى ساليابى [21]

Fig 2: Temporal range for major Quaternary physical dating method. Solid line indicates routine capability

جدول ז: مهمترين روشهاى سال يابى مورد كاربرد در رابطه با مواد مختلف[16-16]

Table 3: the main methods of dating and the applications

\begin{tabular}{|c|c|c|c|c|c|c|c|c|c|}
\hline هيدراته & $\begin{array}{l}\text { أسينه } \\
\text { اسيد }\end{array}$ & $\begin{array}{c}\text { اسيين } \\
\text { الشتريد } \\
\text { ERS } \\
\end{array}$ & $\begin{array}{l}\text { ترمو } \\
\text { لومينسانس } \\
\text { TL }\end{array}$ & رد شكافت & هاى سرى & 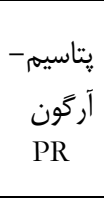 & $\begin{array}{l}\text { رادين } \\
\text { RC }\end{array}$ & $\begin{array}{l}\text { درختى } 1 \text { دابى } \\
\text { Den }\end{array}$ & 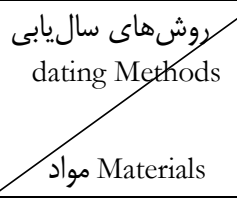 \\
\hline & & & & & & & & & $\begin{array}{c}\text { :وب، كياه، دانه و غيره } \\
\text { Wood, plants, } \\
\text { seeds and etc. }\end{array}$ \\
\hline & & & & & & & & & $\begin{array}{l}\text { استخوان، شاخ، عاج } \\
\text { Bone, horn, ivory }\end{array}$ \\
\hline & & & & & & & & & $\begin{array}{l}\text { دندان و ميناى دندان } \\
\text { Teeth and enamel }\end{array}$ \\
\hline & & & & & & & & & $\begin{array}{r}\text { صدف } \\
\text { shell }\end{array}$ \\
\hline & & & & & & & & & $\begin{array}{c}\text { استالاكيت و كلسيت } \\
\begin{array}{c}\text { Stalactite and } \\
\text { calcite }\end{array}\end{array}$ \\
\hline & & & & & & & & & $\begin{array}{c}\text { سراميك، كل يخته } \\
\text { Ceramic, } \\
\text { Cooked Mud }\end{array}$ \\
\hline
\end{tabular}




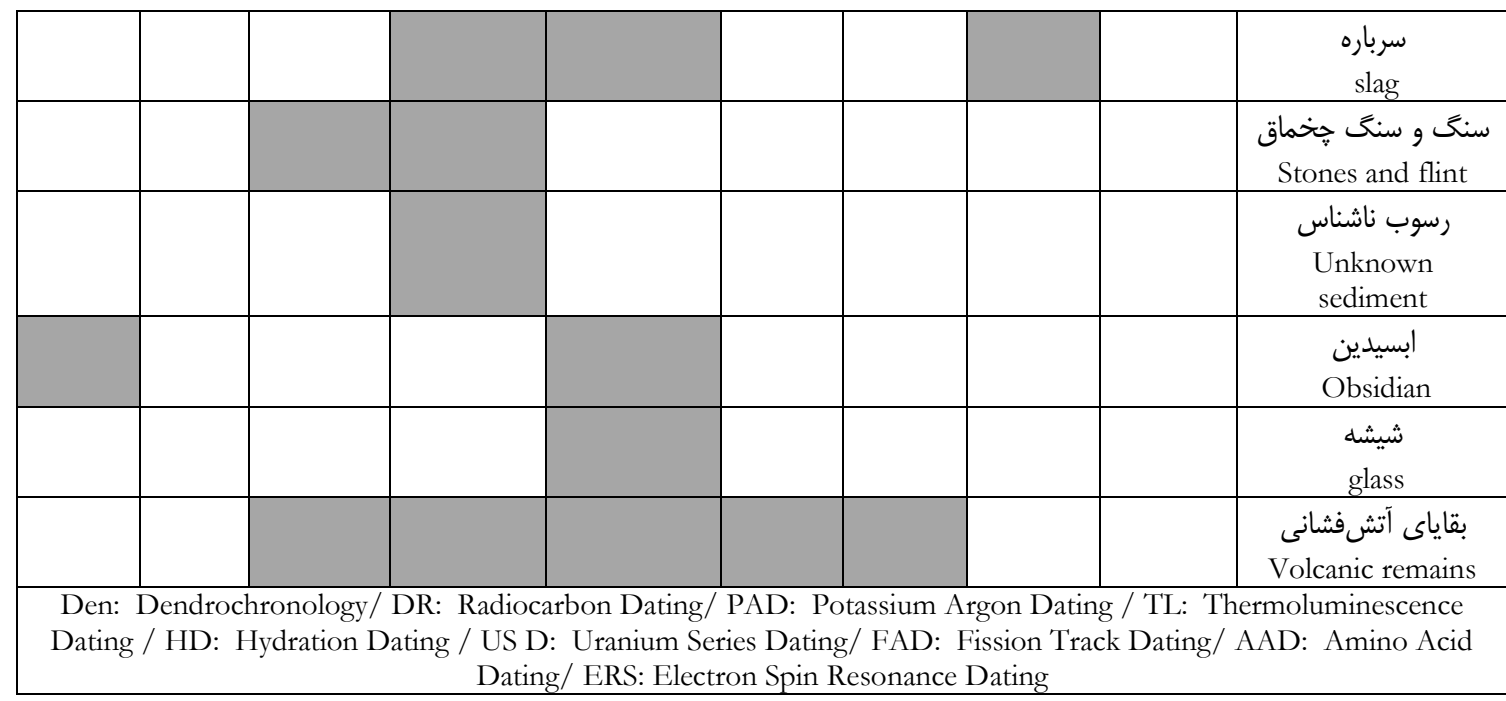

مطالعات در اين زمينه، اثبات كرد كـه ايـن اصـطلاح توصيفى جندان صحيح نيست و بايد از نام علمى آنها "اسنگ كلريت هن استفاده كرد [29].

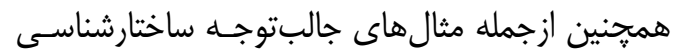

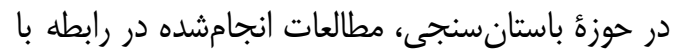

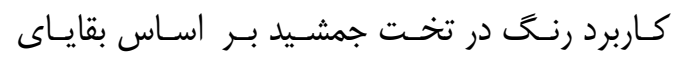

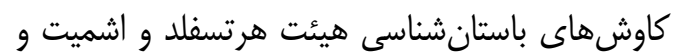

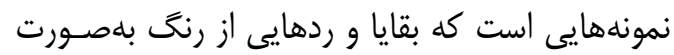

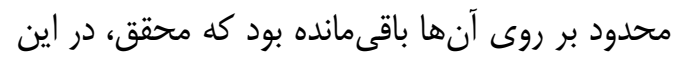
زمينه موفق شد بر اساس ساختارشناسى شواهد اندى

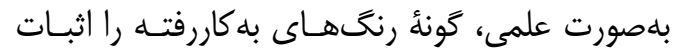

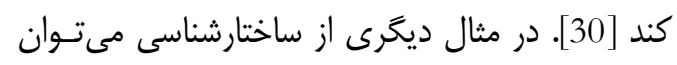

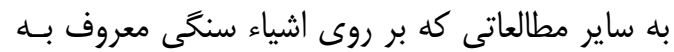
لاجورد در موزه ملى انجام شد، اشاره كـرد كـه در آن بان اثبات شد كلية آنها آبى مصرى هستند و هيجكدام انداز

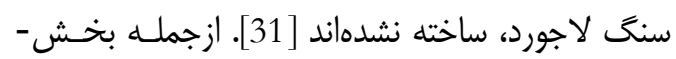
هاى مهم مطالعات ساختارشناسى در باسـتانسـنجى

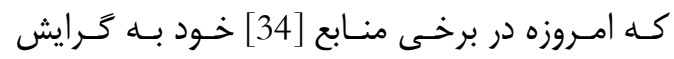

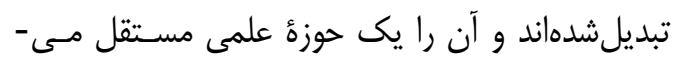
دانند، مى توان به شناخت فعاليـت انسـانى ( Human فctivity

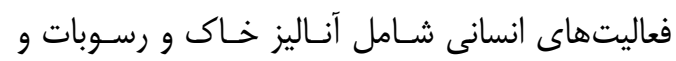

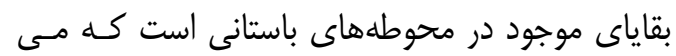

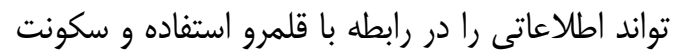

\section{r-r. حوزهُ مطالعاتى ساختارشناسى و منشأيابى} مطالعات ساختارشناسى را مىتوان بهمنزلئ اسـتفاده از

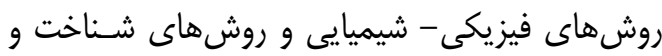

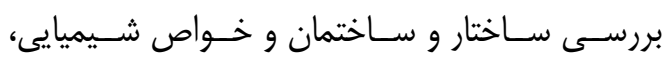
فيزيكى مواد در نظر كرفت. اين مطالعه، در رابطـهـ بـا

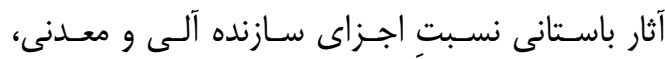

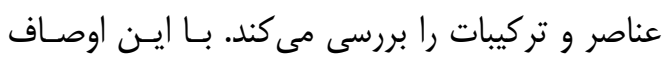

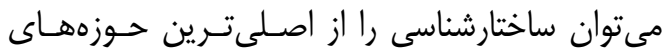

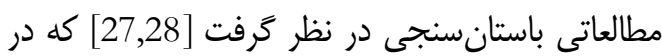

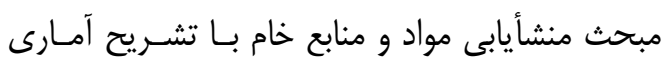
مناسب كارايى بالايى دارد [6].

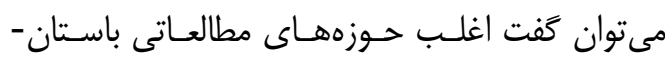
سنجى، نخستين كام را در ساختارشناسى مواد باستانى

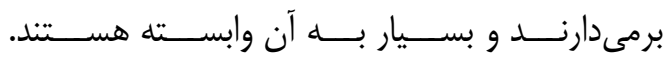
ساختارشناسى بالينكه مى تواند راهخشاى ديخر حوزهـها

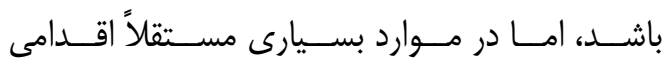
باستانشناسى قلمداد مى شـود. بــهور مثـال، تعيـين

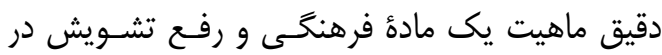
رابطه با آن و استنباطهاى متفاوتى كه در منابع آمده،

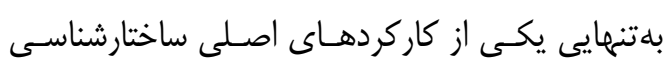

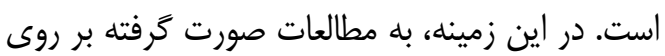

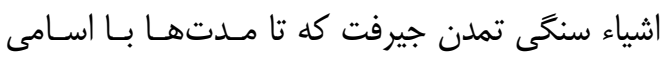

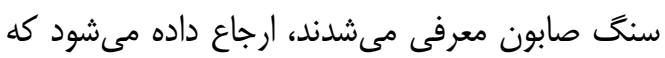


است كه بنيان مسئلة منشأيابى در ساختارشناسى مواد موجود و منشأهاى احتمالى آنها استوار است.

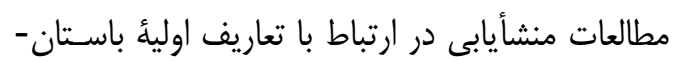

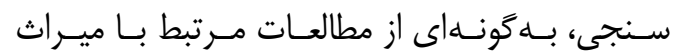

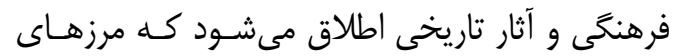

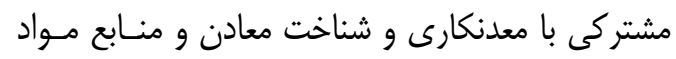

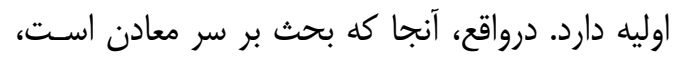

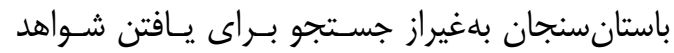
علمى مبتنى بر ساختارشناسى و نيز مقايسه و تطبيـق مواد فرهنگى و اجز// اشياء تاريخى با معادن، به دنبال شواهد باستانى و اقدامات معدنكارى باستانى (مانند رد

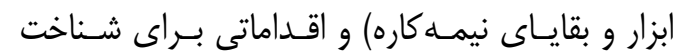

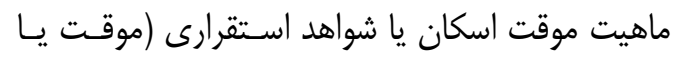

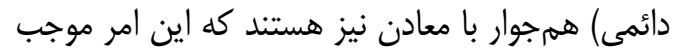

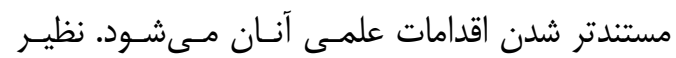

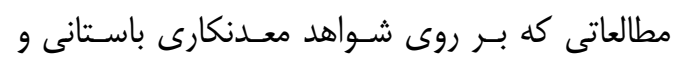

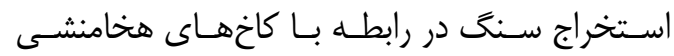
برازجان انجامَرَفته است [34]، مطالعاتى كه در رابطه

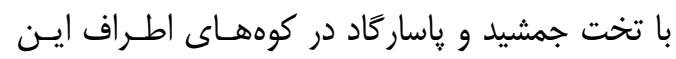
ابنيه صـورت يذيرفتـه اسـت [35]. مطالعاتى كـه در

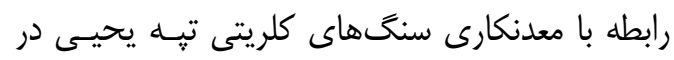

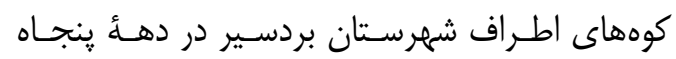

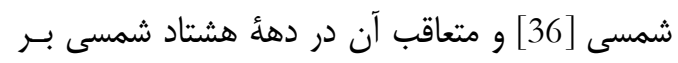

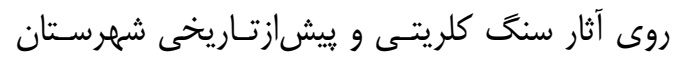
جيرفت در معادن و منابع اطـراف آن صـورت كرفتئه است [29]. در بررسى ويزگى تمامى ايـن مـوارد كـهـ

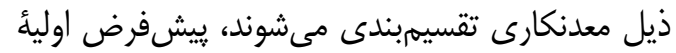

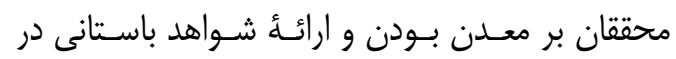

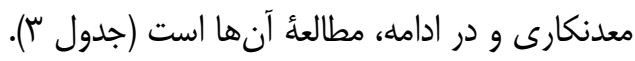

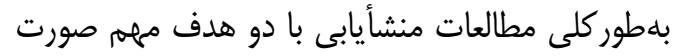

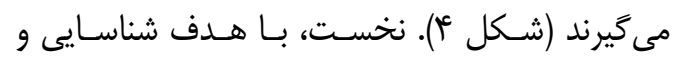
تطبيق مواد فرهنكى تاريخى بلهدست آمده از محوطههاى تاريخى با معادن، منابع و منـاطق باستانى كـهـ

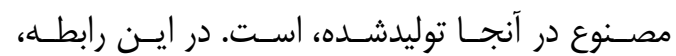
سئوالات متعددى كه در رابطه بـا بـومى بـودن و و يــا

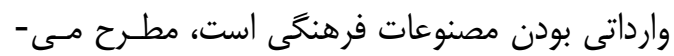

انسان و حيوانهاى اهلى آن، نحوهُ سكونت و استفاده از بخشهاى مختلف محوطه تاريخى بلهمثابه كاركـاه،

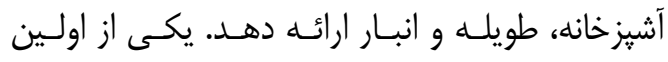
كاربردهاى اين نوع، تجزيهوتحليل فسفات موجـود در

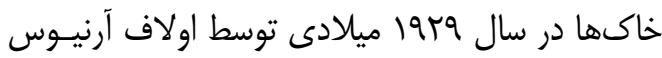

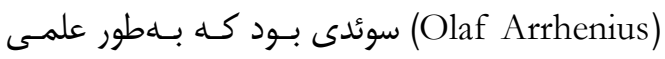

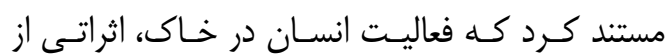

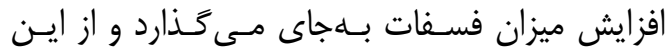

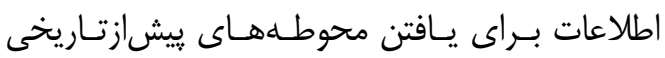

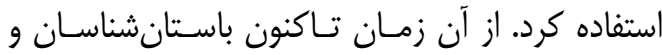

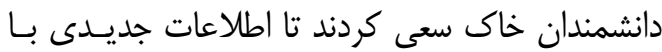

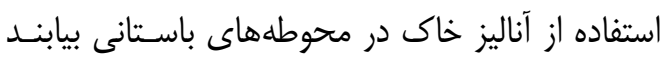

منشأيابى، از ديخر حوزههاى مهم باستانسنجى است

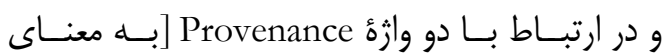

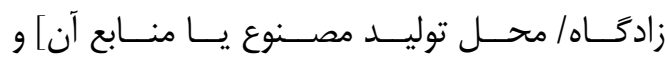
افتئاه يافتخاه و زمينه (Context) باستانشناسى] است كـه

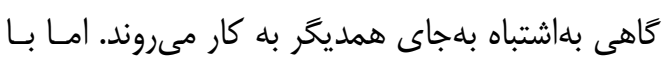

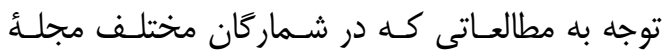
Archaeometry اين نكته برمىآيد كه مهمترين سئوال مطرح در حوزه

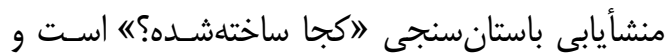

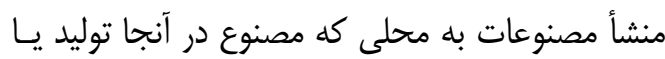

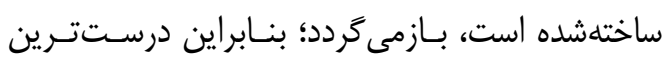

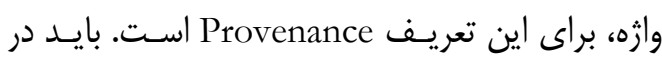
نظر داشت كه طيف وسيعى از فعاليـتهـاى مختلـف

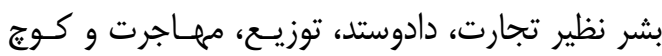

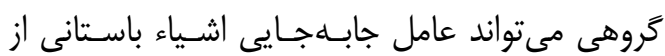

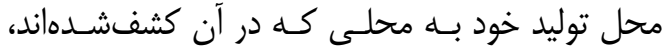

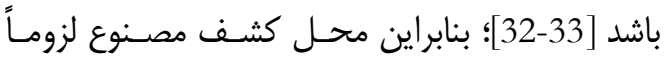

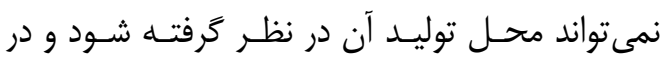

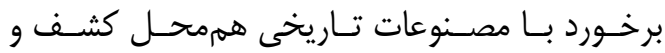
هممحل توليد موردتوجه اسـت كـه حـوزئ تحقيقـات

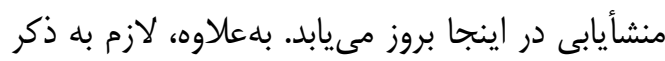


مرمت و يا جايخزينى آثار فرسوده شده). بـهــلاوه از مطالعات منشأيابى براى بازسازى روند توليد يـا درى

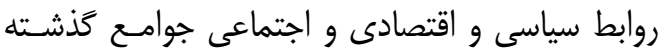

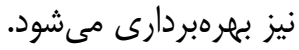

شود. ديخر، با هدف مطالعه براى يـافتن منـابع مـواد خام جهت استفادهاى در ارتباط بـا ميـراث فرهنخـى

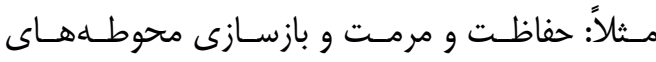
باستانى، منشأيابى صورت مى گيرد (مثلاً يافتن معادن

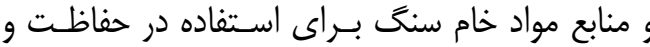

\begin{tabular}{|c|c|c|}
\hline 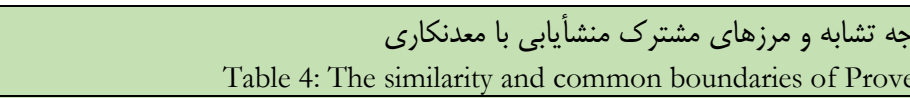 & $\begin{array}{l}\text { جدول } \\
\text { ace with the mining }\end{array}$ & \\
\hline $\begin{array}{c}\text { اهداف باستانسنجى } \\
\text { Archaemetrical Objectives }\end{array}$ & $\begin{array}{c}\text { زيرشاخها } \\
\text { Sub-branches }\end{array}$ & \\
\hline $\begin{array}{c}\text { شناسايى و تطبيق مواد فرهنگي محوطههاى تاريخى با معادن، منابع و مناطق باستانى } \\
\text { Identifying and matching the cultural materials of historical sites with } \\
\text { mines, resources and ancient sites }\end{array}$ & $\begin{array}{c}\text { ساختارشناسى } \\
\text { Characterization }\end{array}$ & \\
\hline $\begin{array}{c}\text { بازتوليد منابع و بهكارگيرى در تركيب با آثار تاريخى } \\
\text { Reproduction of resources and use in combination with historical } \\
\text { monuments }\end{array}$ & $\begin{array}{l}\text { فناورى } \\
\text { Technology }\end{array}$ & Provenance \\
\hline $\begin{array}{c}\text { استخراج منابع اوليه كانى از معادن } \\
\text { Extraction of primary mineral resources from mines } \\
\end{array}$ & \multirow{2}{*}{$\begin{array}{l}\text { منابع مواد خام اوليه } \\
\text { Sources of Raw } \\
\text { Materials }\end{array}$} & \multirow{5}{*}{$\begin{array}{l}\text { Mining } \\
\text { Meكilv }\end{array}$} \\
\hline $\begin{array}{l}\text { جستجوى شواهد علمى در راستاى شناسايى مراكز فعاليتهاى صنعتى } \\
\text { Searching for scientific evidence to identify centers of industrial activity }\end{array}$ & & \\
\hline $\begin{array}{c}\text { مقايسه و تطبيق يافتههاى باستانى با معادن } \\
\text { Comparison and matching of ancient findings with mines }\end{array}$ & $\begin{array}{l}\text { معادن فلزات باستانى } \\
\text { Ancient Metal } \\
\text { Mines } \\
\end{array}$ & \\
\hline $\begin{array}{c}\text { يافتن شواهد معدنكارى باستانى (مانند رد ابزار و بقاياى نيمه كاره) } \\
\text { Find ancient mining evidence (such as rejection of tools and semi- } \\
\text { finished remains) }\end{array}$ & \multirow{2}{*}{$\begin{array}{c}\text { منابع سنگ هاب } \\
\text { Stones Sources }\end{array}$} & \\
\hline $\begin{array}{c}\text { اقدام براى شناخت ماهيت شواهد استقرارهاى موقت همجوار يا نزديك معادن } \\
\text { Take action to identify the nature of evidence of temporary settlements in } \\
\text { the vicinity of or near mines }\end{array}$ & & \\
\hline
\end{tabular}

نبودن حتى در دورة باستان نيز شناختهنشده بودند يـاـ مى توانستهاند بر اساس آنـاليز تركيبـات مورداسـتفاده،

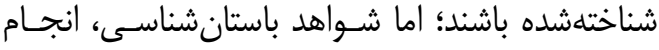

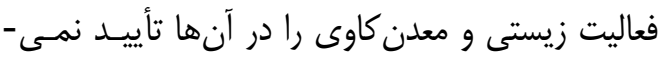
كند. ازاينرو، محققان، آنها را بلعنوان منـابع بـالقوه

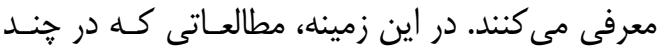

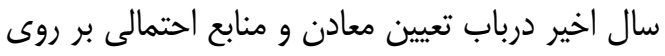
ابسيدينهاى سهند انجام گرفته است، قابلذكر هستند

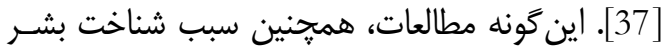

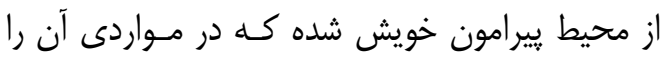
نيز دهار ييشرفت كرده است. لازم به ذكر است كه در در

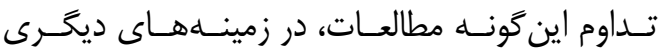

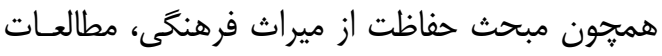

از طرفـى در ايــن مبحـث، وازئ ديخـــى بــا عنـوان

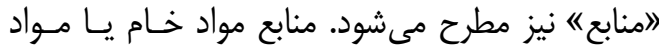

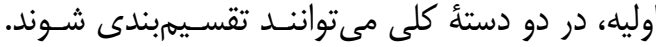

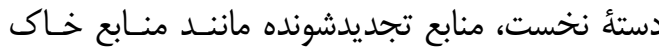
رس، آميزه و مواد افزودنى هستند كه بعضاً در دلتـاى نائ رودخانهها بلهصورت فصلى رسوب مى كنتــد و امكـان استفاده از اين منابع مىتوانسته در هزاران سال بـراى ساكنان حواشى اين نواحى جهت ساخت سفال و آجـر

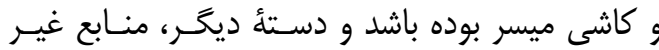

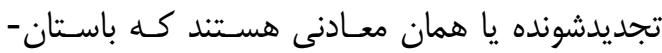

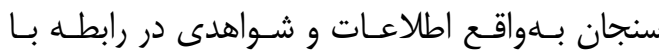
استقرار و يا معدنكارى در آنها نيافتهاند ولى مى توانتند تخمين بزنند كه ايـن منـابع بـاوجود مسـتعد بـودن / 
نهم دارد. مقايسُٔ دادههاى ايزوتـويى الرقـه بـا نتـايج منتشرشده از ديخر شيشههاى خاورميانه و آلمان نشان

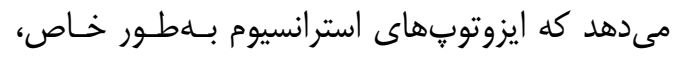
ابزار قابلاعتمادى براى تمايز بـين منــابع مـواد خـام شيشه خاكستر كَياهى هستند و اين امر در مـورد اثـر

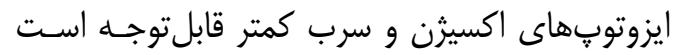

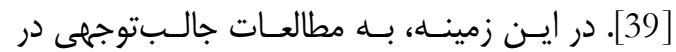
مجموعه مقالات باستان متالورزى در ديـدكاه جهانى

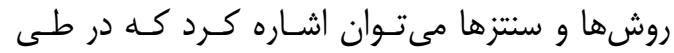
مقالات متعدد به جنبههاى مختلف باستان متـالورزى بلمثابه يكى از شاخههاى باستانسنجى يرداخته شـده

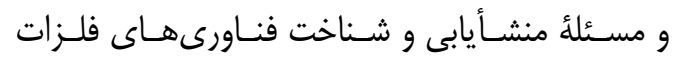

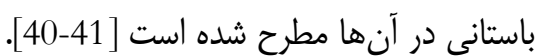

جالـبتوجهى درزمينــُ نكَهـــارى از معـادن تـاريخى

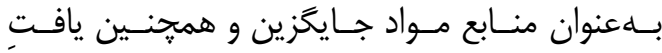

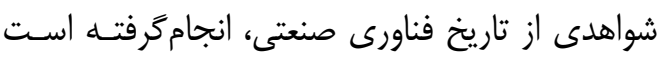

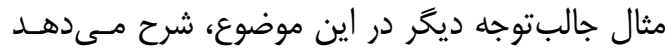
كه تعيين ايزوتوٍهاى اكسيثرن (O)، استرانسيوم (Sr)

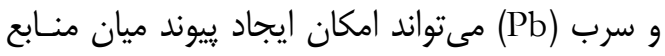

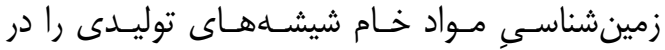

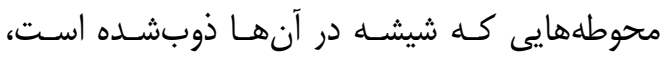

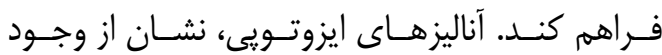

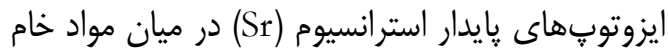
ساخت خاكستر كياهى و شيشـههاى نـاترونى (نمـك

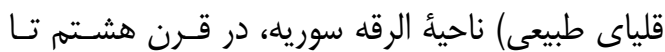

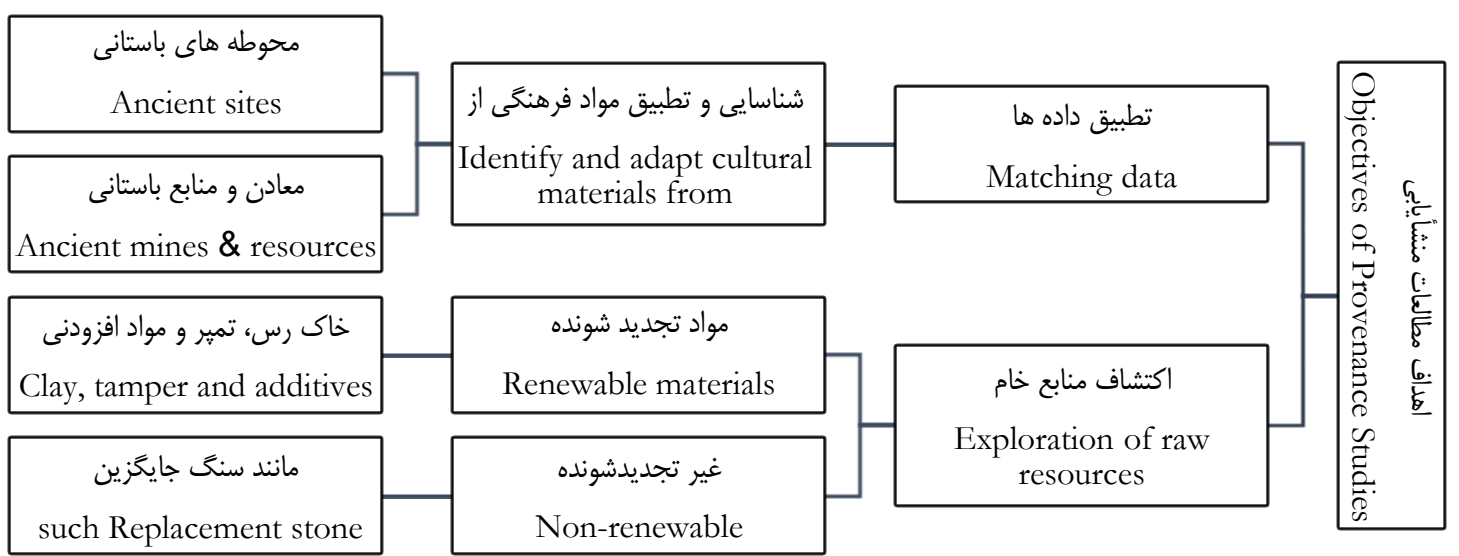

شكل عا: برخى از اهداف مطالعات منشأيابى در باستانسنجى :

Fig 4: Objectives of Provenance Studies

در ياتين، اصالت در شكل و فرم، اصـالت در نقـش و

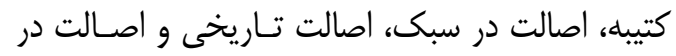
انتساب) را نداشته باشد [42]. همجنين اصالتسنجى،

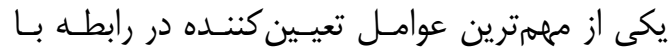

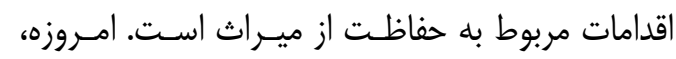
اصالت در سادهترين وجه، به معناى وجود مواد اصـلى حفالى

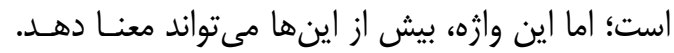

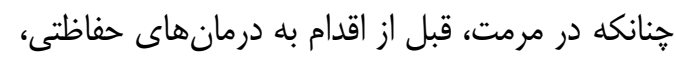

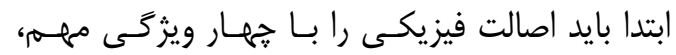
تشخيص داد و در نظر گرفت: اصالت در مواد، اصالت

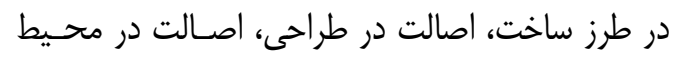

ץ-". حوزه مطالعاتى اصالتسنجى اصالت (Authenticity) را مىتوان اصلى، دستاولى اصلى

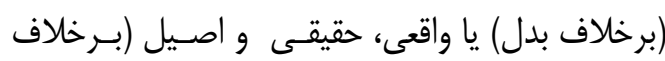

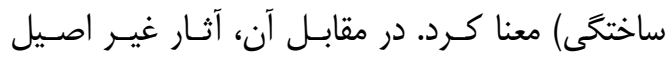

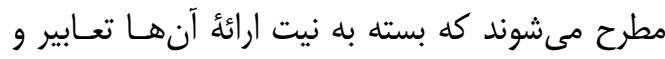

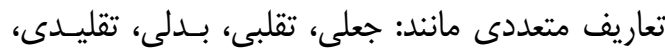

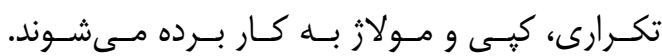

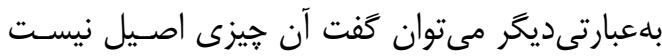

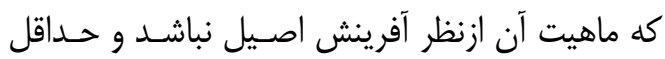

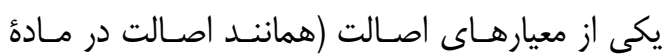
اصلى، اصالت در فن ساخت، اصالت در آسيب، اصالت 
با استفاده از اطلاعات كيفى ناشى از مطالعات تطبيقى

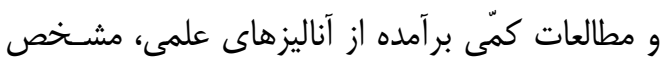

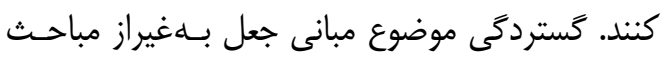

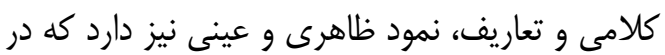

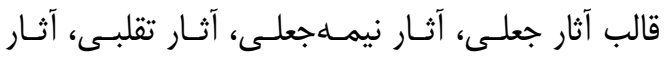

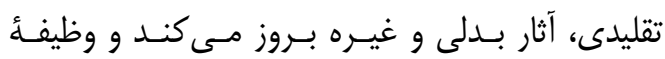

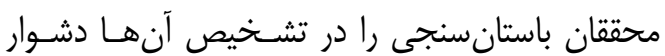
مى گر داند [48-42]. بررسى اصالتسنجى اشياء تاريخى و باستانى، شـامل

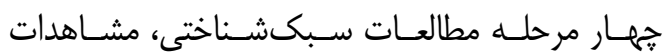

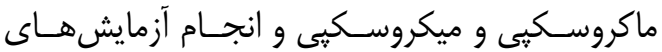

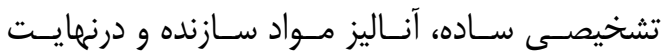

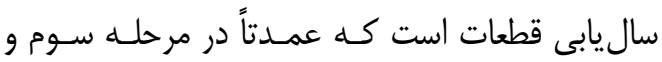
جهارم، باستانسنجان درگير مسئله مى شوند و مرحلــ

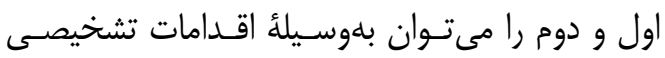
مرمتكران آثار فرهنكى و تاريخى و باستانشناسان به به انجام رساند و البته استثناهايى نيز در اين زمينه وجود دارد [47]. در تعريف اصالت بايد توجه داشـت كـهـ ايـن وازه، در

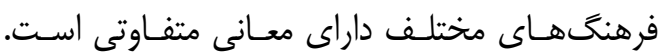
همجنين اصالت و تغييرات آن لدر دورههاى تـاريخى مرهى و دورة مدرنه تفاوت دارند. ميزان مداخله در اقدامات

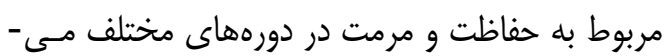

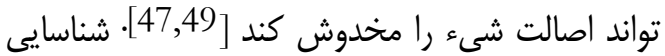

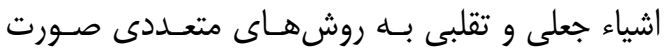

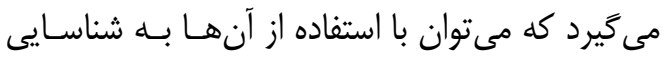
اشياء مشكوك يرداخت. به عنوان مثال، نـور مـاوراء-

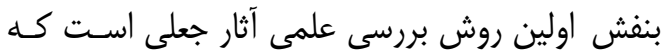

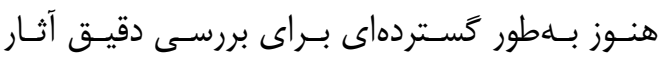

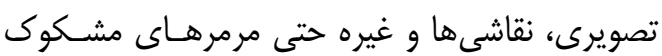

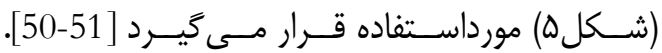

رِّرِيرامون. اين جهار شـرط تعيـين اصـالت، در مصـوبأُ

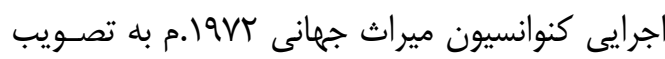
رسيده است و شايد بتوان براى هر اثرى به كار كرفت

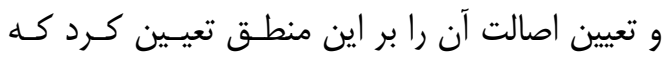

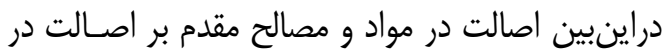
طرح و طرز ساخت و محيط و بسـتر فرهنخى اسـت بايد توجه داشت كه مطرح كردن اصـالت، توجـهـ بــهـ شكل و ساختار اصلى را محدود نمى كند، بلكه شـامل داتل

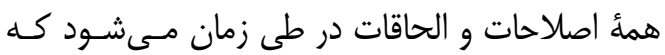

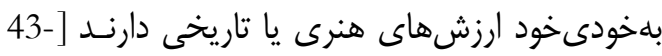

اصالت در حوزههاى تشـخيص مـواد سـازنده، شـيؤه ساخت، شناسايى نقوش و اشكال و كتيبهها بـهـعاوها

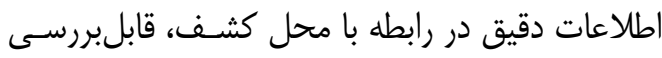

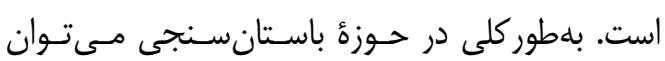

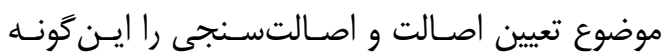

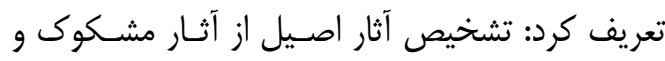

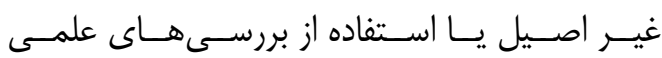

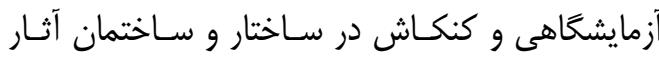

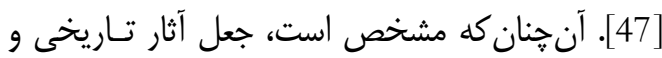

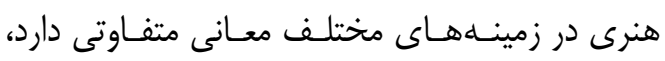

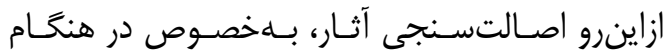

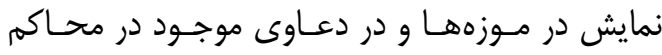

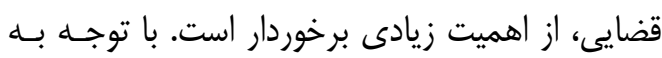
اينكه در زمينُٔ جعل آثار تاريخى ابعاد مختلفى ازنظـر

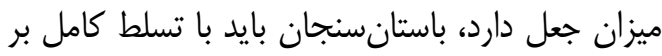

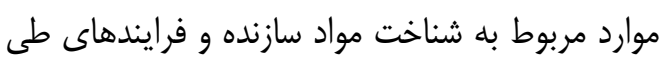

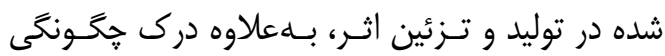

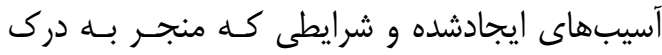

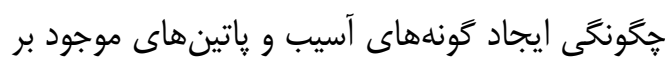

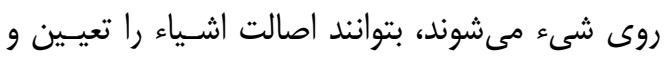

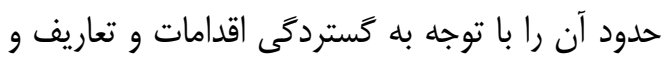



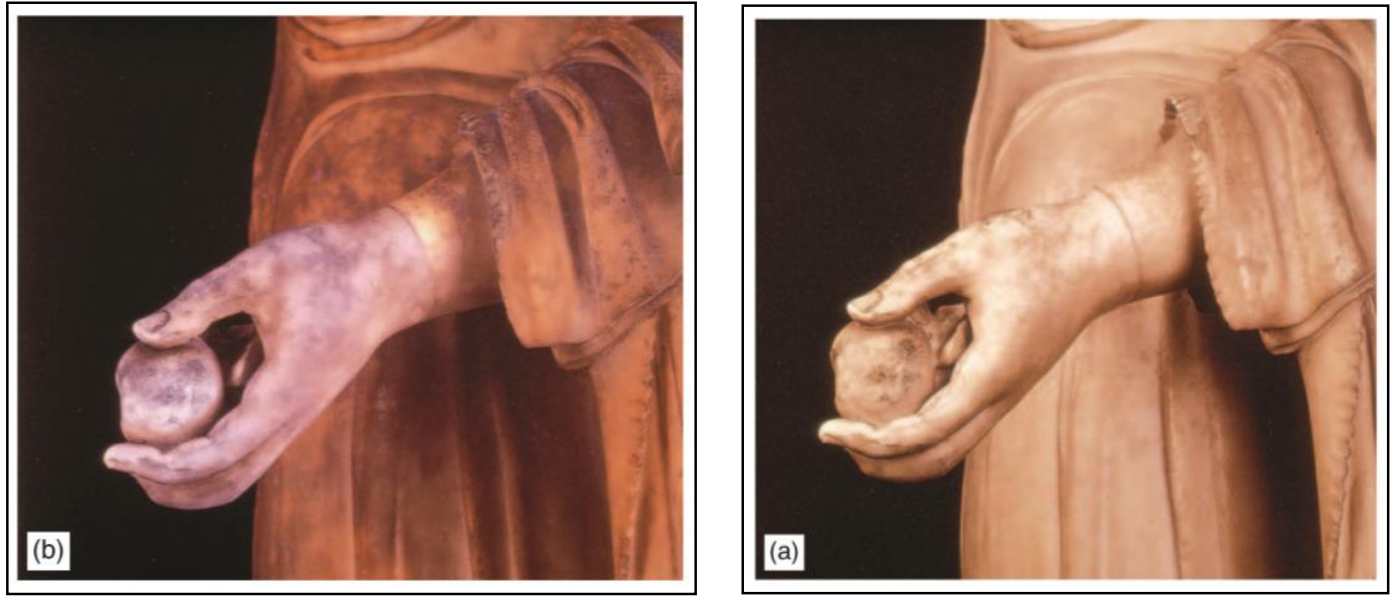

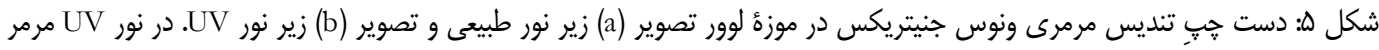

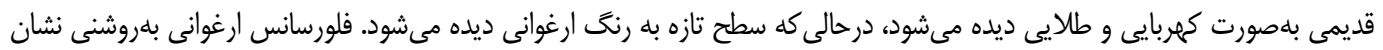

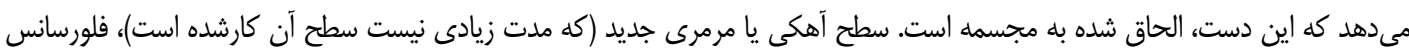

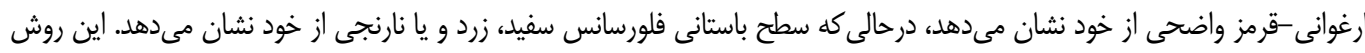

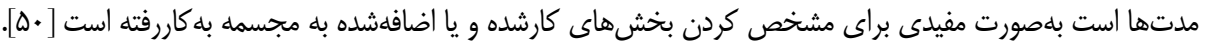

Fig 5: UV light Life-size marble statue, Venus Genitrix, Louvre UV light reveals that the hand is not the original Douma, .M. curator. "Ultraviolet (UV) Light. In Pigments through the Ages

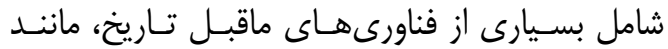
ساخت ابزارآلات سـنكى و متـالورزى بـود [52-53. رابرت اشجر (1991) اولين فردى بود كه رسالأ نظرى

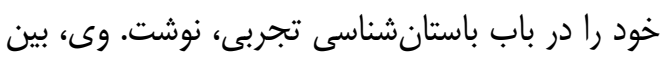

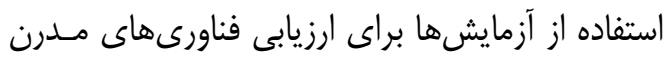

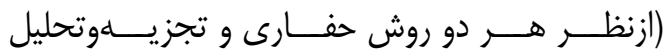

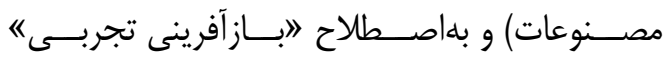
تفاوت قائل شد. از ديدكاه او در آزمايش تقليدى شـكل دادن و اسـتفاده كـردن،

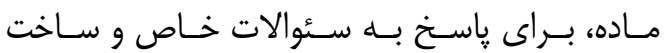

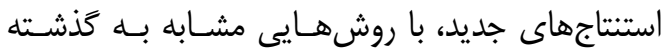

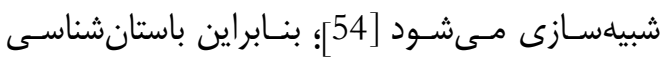

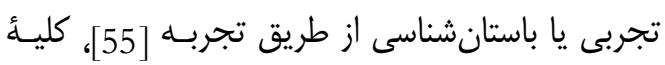

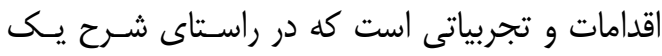
موضوع باستانشناختى كام برمىدارد [52].

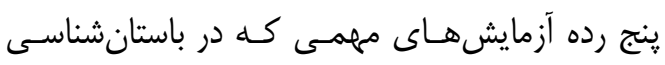
تجربى موردتوجه قرار مى گيرند شامل:
ع-ب. حوزه مطالعاتى شناسايى كاربرى اشياء و بازسازى فناورىهاى باستانى

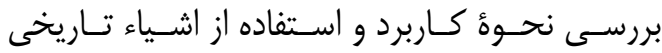

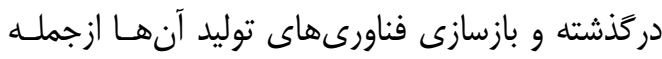

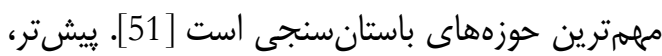

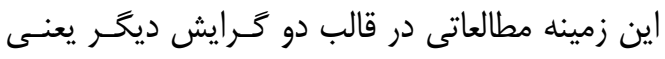

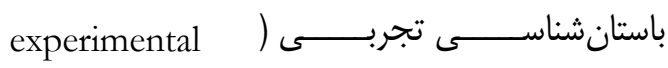
(archaeology

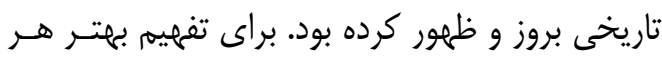

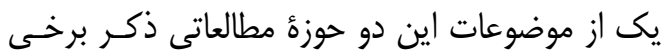

$$
\text { مفاهيه، لازم به نظر مىرسد. }
$$

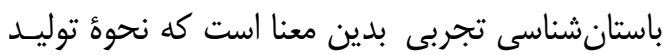

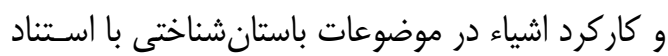

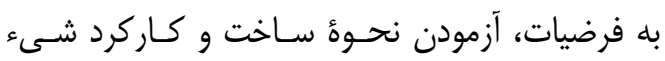

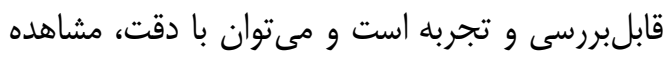

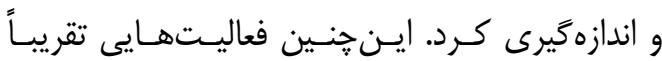
بكاندازه رشتأ باستانشناسى، قديمى است و از همـان ابتدا شاخهاى از آن محسوب مىشد و نمونههاى اوليه 
استفاده از تجربيات بلمنظور بازآفرينى و آزمـون فرضيات مختلف درباره گذشته

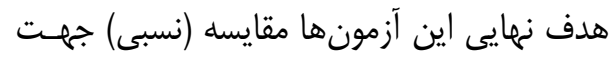
تفسير و تحليل نشانههاى فرايندها و كنشهـاى إنى

كذشته است [57].

ازاينرو اهداف اصلى باستانشناسى تجربى راس را مى توان بر سه مورد كلى تقسيم كرد كه شامل مورد زير است:

ا. تقويت دانش در مورد متالورزى باستان؛

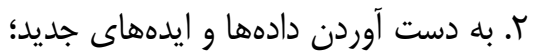
ب. تأسيد يا جعل فرضيه [52]. نيز مطالعه فناورى نقش مهمـى در انجـام مـداخلات

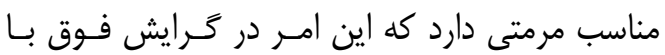

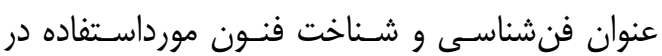

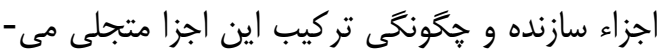

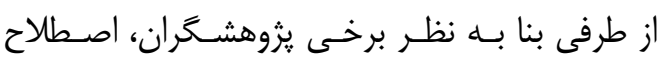

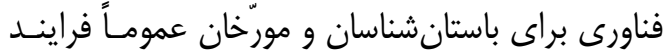

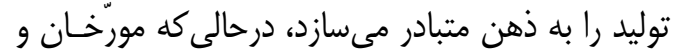

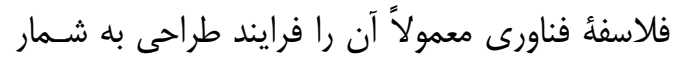

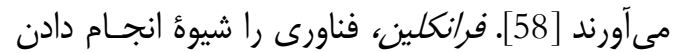

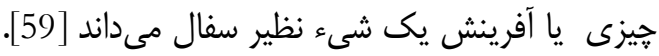

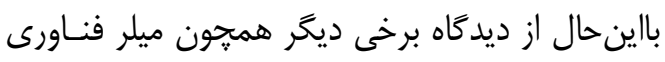
شامل: فرايندها، فعاليتهاى مرتبط با توليد و مصـرف ديك دمرف

$$
\text { از طراحى تا دورريز است [60]. }
$$

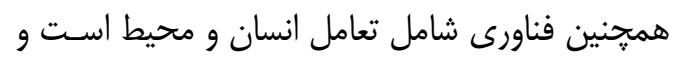

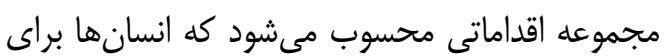

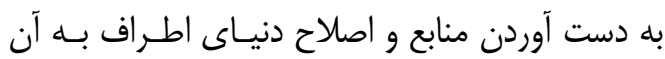

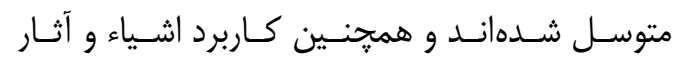

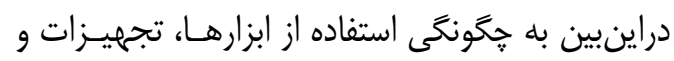

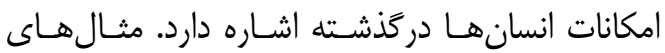

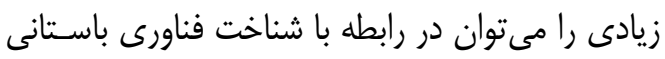

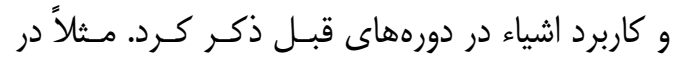

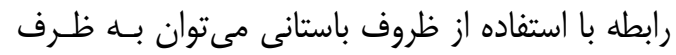

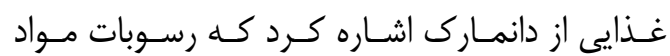

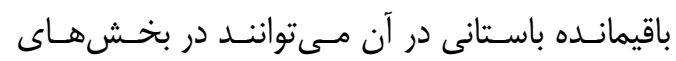

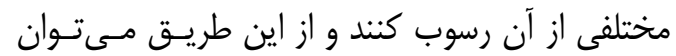

1. ساختوساز (Construct): آزمايش فرضسى بـراى

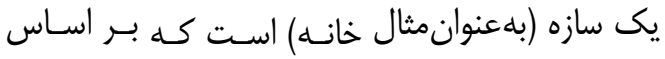

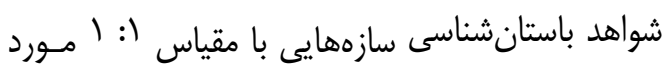
آزمايش واقع مى شوند، با ايـن فرضـيه كـهـ آيـا داراى إي ايستايى است يا مى افتند.

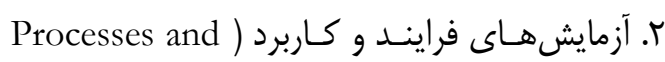
(function experiments جَحونكَى دستيابى به امور كذشته كه شامل تحقيقـات

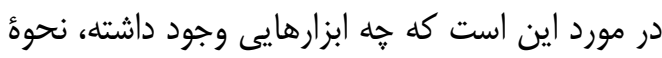

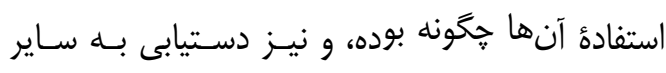

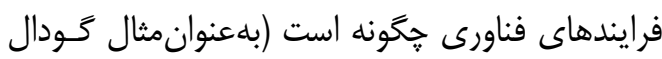

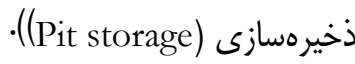

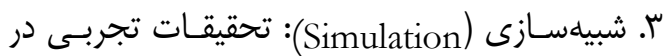

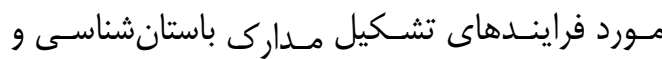
تافونومى پِ از رسوب است. زأ. آزمـايش احتمـالى (Eventuality trial)

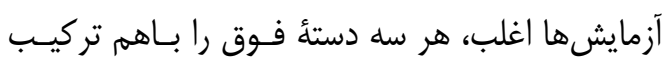

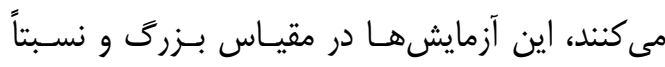

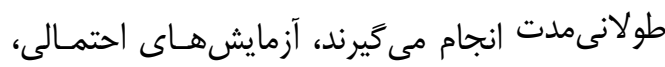

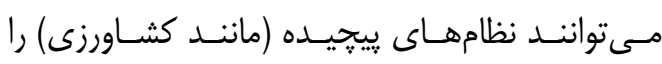

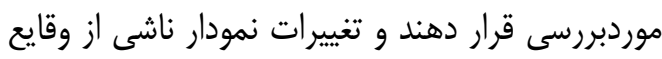

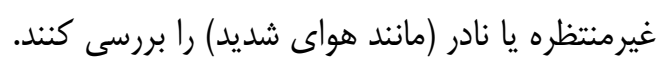
ه. نوآورى فناورانسه (Technological innovation) در اين مورد خود روشهاى باستانشناسى در حـالات

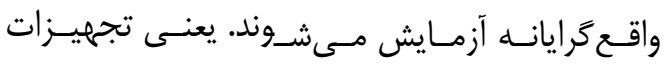

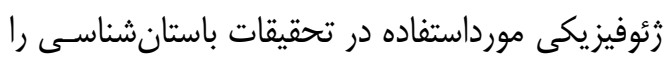

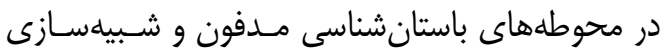

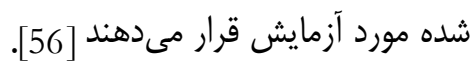

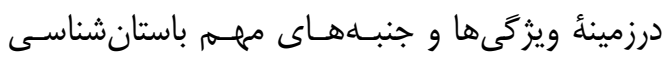
تجربى، متيو، به جهار جنبأ ذيل اشاره مى كند:

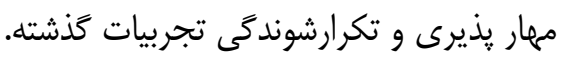

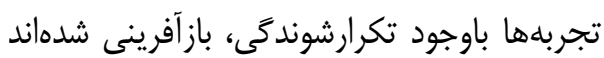

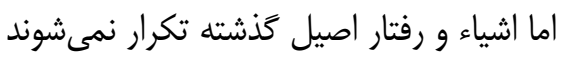


جوشيدن مواد غذايى به وجود آمده است. بخـش دوم

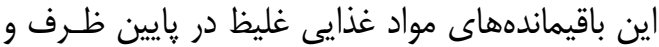

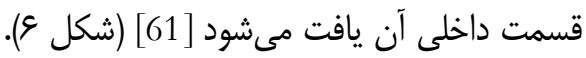

متوجه شد كه از اين ظرف جـهـ اسـتفادهاى در دوران

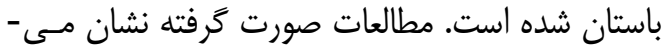
دهند كه غليظترين آثار و بقاياى غذايى بر روى لب و

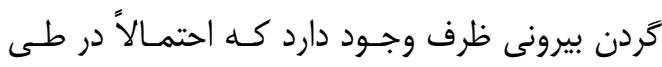

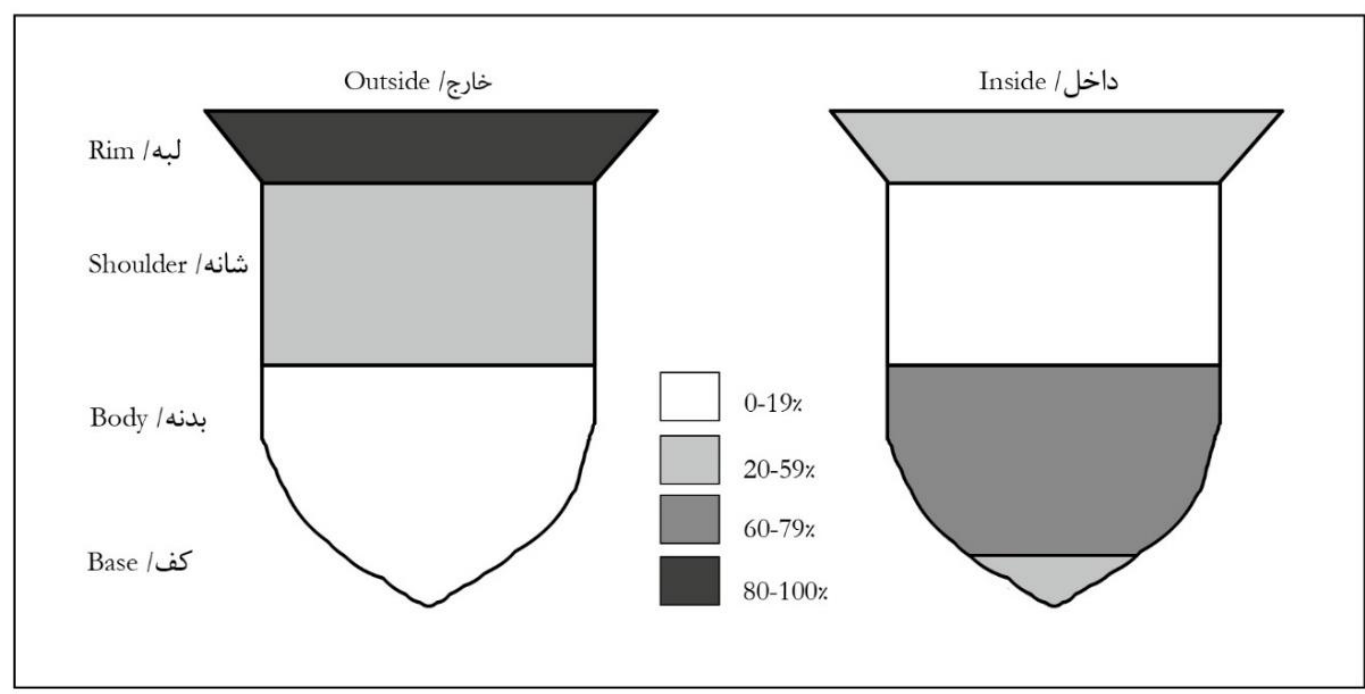

شكل ع. آثار تختويز و باقىماندهاى آن در داخل و خارج از سفالهاى مزوليتيك (Mesolithic) از محوطه تايبريند ويح، دانمارك. مناطق

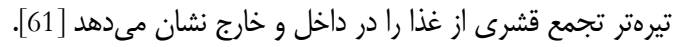

Fig 6: Cooking traces and residues on the inside and outside of Mesolithic pottery from the site of Tybrind Vig, Denmark. The shaded areas show the concentration of food crusts inside and out

حوزههاى مـرتبط بـا باسـتانسـنجى ذكرشـده اسـت

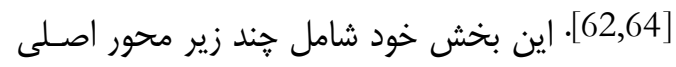
است كه بلهورت كلى عبارت هستند از: - مطالعـهـ در مكانيسـهم تخريسب و فرسـايش مــواد مختلف در طى زمان؛ - مطالعه در روشهاى نوين حفاظت و مرمت و مــواد مورداستفاده و مطالعة برهم كنش هاى ميـان مـواد بـاــا

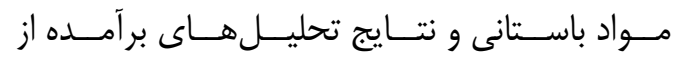
آزمايش هاى باستانسنجى [63].

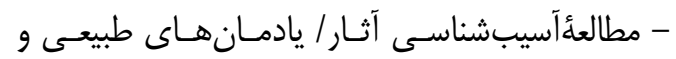

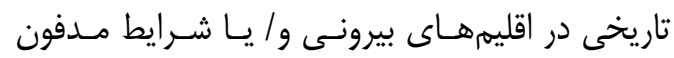
خاكى / آبى؛ اين گَونه مطالعات خود در تحليل مطالعات منشأيابى و ساختارشناسى براى مواد تاريخى كه دجار تزلزل و تخريبهايى در ساختار شيميايى خود شدهاند، ضرورى است [51].
در مطالعات باستانسـنجى، مطالعـهُ فنـاورى جنــدين موضوع را دنبال مى كند. نخست بررسى خود فناورى،

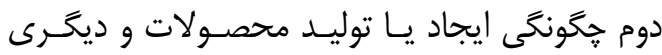

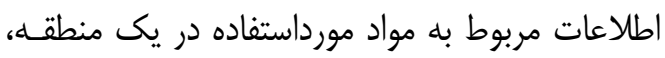

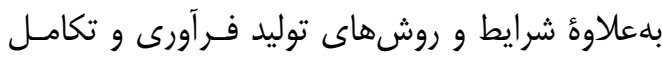

$$
\text { فناورى را در برمى تيردا }
$$

\section{ه-r. حوزهُ مطالعاتى دانش حفاظت آثار

اين حوزه، شـامل مطالعـات شـيميايى - فيزيكـى در

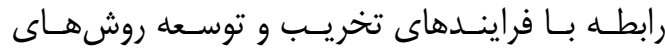
درمانى جديد در حفاظت و مرمت از اثر است كه ذيل

مطالعات باستانسنجى بدان ״رداخته مىشود [6].

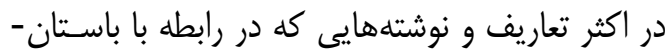

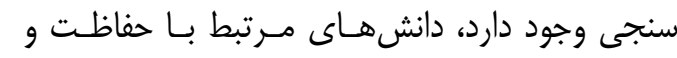

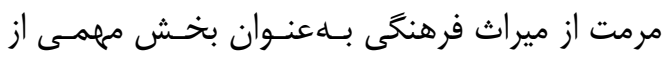


قرار كرفتهاند و زمينه براى طـرح مسـائل مهـمتـر در

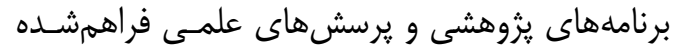

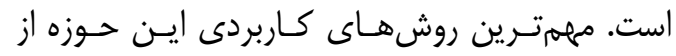
مطالعات باستانسـنجى را مـىتـوان ذيـل دو محـور اصلى سنجش از راه دور و وِيشيشيـابى بــا اسـتفاده از روشهاى زئوفيزيك دانست. حوزه دورسنجى شـامل

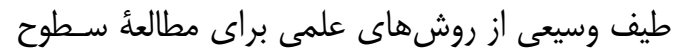
زمين و زيرزمين از فواصل دور و نزديك است كـه بــاــا

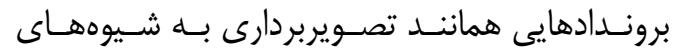

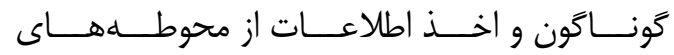

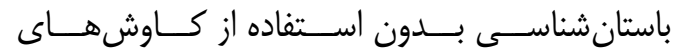

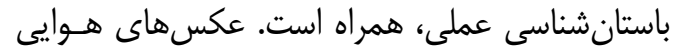

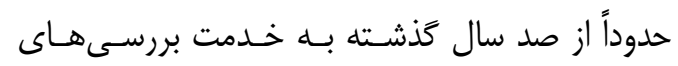

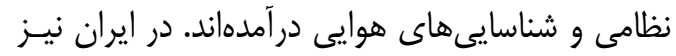

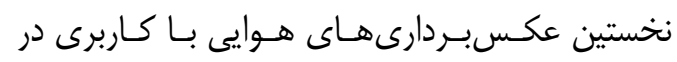

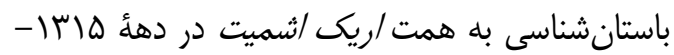

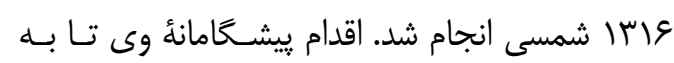

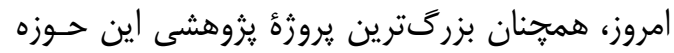
در ايران است و عكسهاى هوايى او كماكان تصاوير

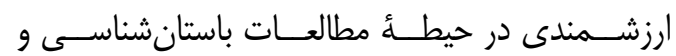

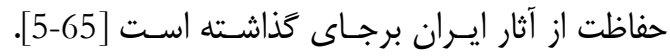

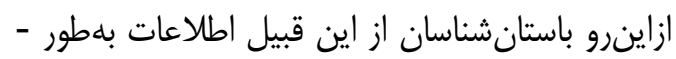
ويزّه براى شناسايى و مستندسازى و وايش محوطـهـ-

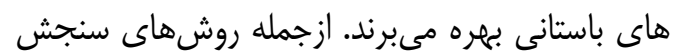

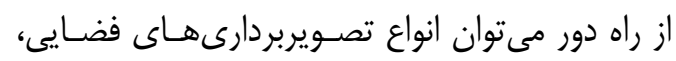
هوابرد و سامانههاى زمينى را برشمرد (شكل V) أنوان.

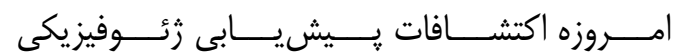
(Geophysical prospecting)

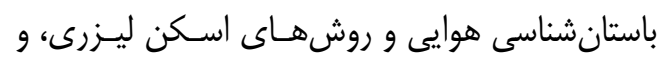

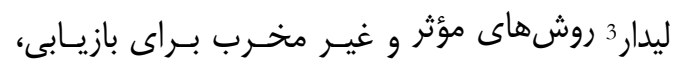
درى و ييخيرى تحقيقات باستانشناسى هستند [66].

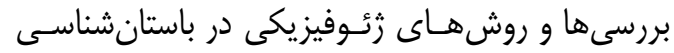

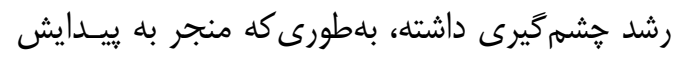

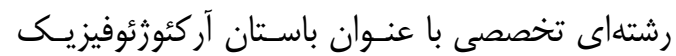
شـــــ (Archaeo-Geophysics)

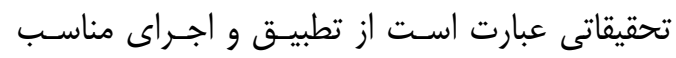

- مطالعُ ويثزى هاى عملكردى و خواص ذاتسى مـواد

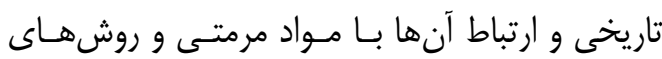
حفاظتى [63]. - تئورى هايى كه وابسته به شـناختهـاى حاصـل از از

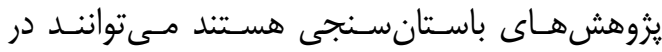
اقدامات حفاظتى تأثير كذار باشند.

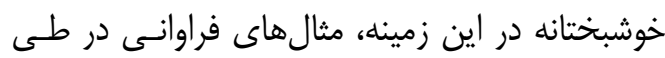
جندين سال آموزش دانشـاهى در زمينـه حفاظـت و ورئه

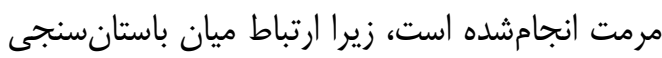

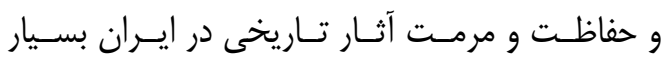
متفاوتتر از كشورهاى ديخر است. بلهنحوى كه تـا بـهـ

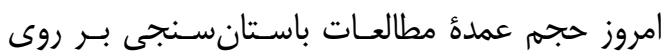

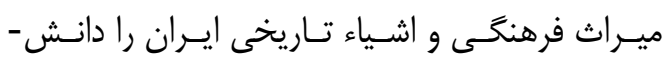

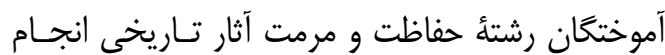

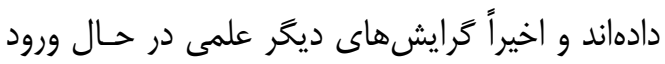
به عرصُٔ باستانسنجى هستند.

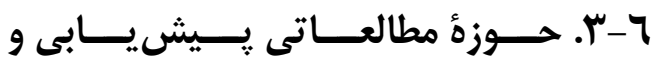

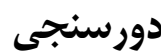

روشهاى كاوش و مطالعات باستانشناسـان امـروزى دورى نسبت به عملكرد سنتى دركَشته ييشرفتهاى شايان

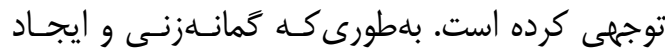

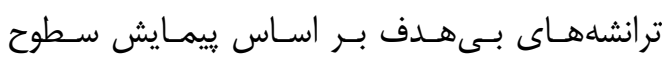

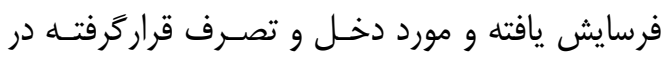
محوطة شناختهشده قبلى ديكر كارايى جندانى ندارد و

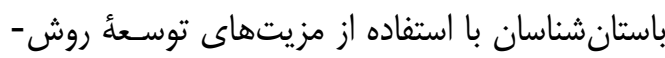

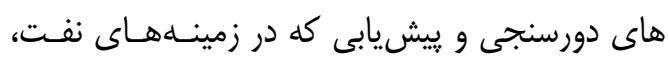

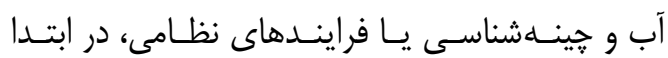

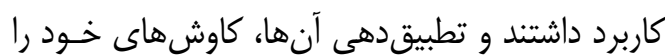

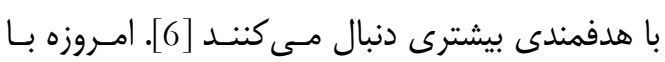
حمايت روشهاى ييشيابى از اقدامات باستانشناسان

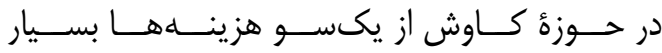

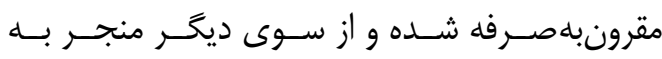

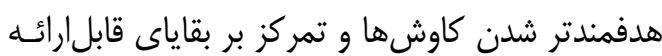

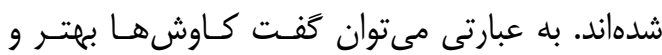

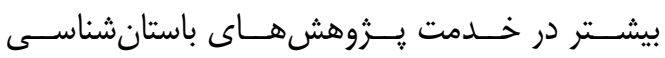


داراى تفاوتهاى فيزيكى محسوسـى اسـت، در زيـر سطح زمين آشكار كرد [69-68-67].

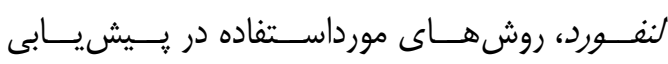

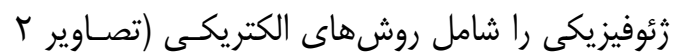

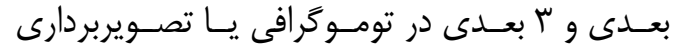

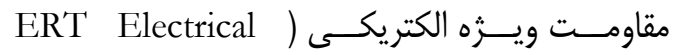

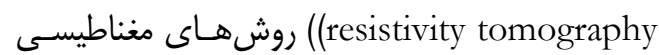
(با مغناطيس

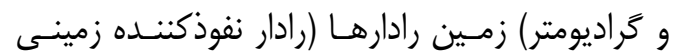
(GPR و عكاسى هاى هوايى و مـاهوارهاى مسىدانسد

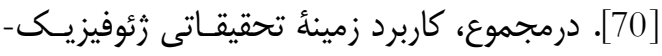
باستان در علوم ميراث فرهنگى شامل استفاده از ابزار فنى براى مكانيابى، نقشهبردارى و توليد تصاويرى از مواد فرهنگ

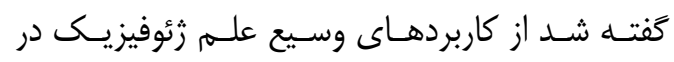

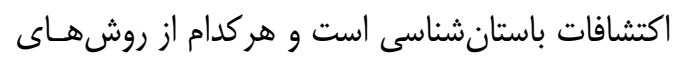

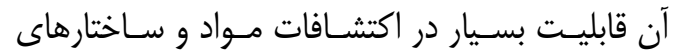
باستانى دارند، اما انتخاب روش مناسب داراى اصول و

$$
\text { اهميت ويزهاى است [71]. }
$$

روش هــاى زئوفيزيـــ اكتشـافى در محوطـهـهـاى باستانى كه بـا اسـتفاده از ارزيـابى تغييـرات فيزيكـى رولى

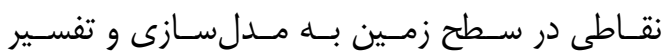

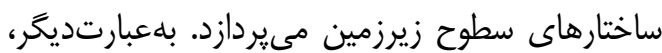
بررسـىهـاى زئسوفيزيكى (Geoghysics) مجموعـهـ روش هايى هستند كه در راسـتاى ثبـت ويزگ

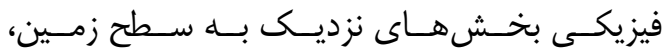

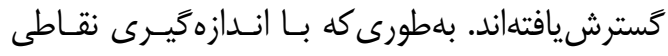

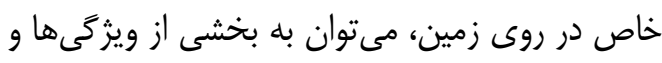

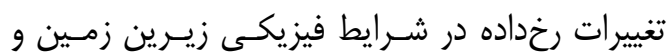
تفاوتهاى موجود در نقاط مختلف يـى بـرد. انسدازه-

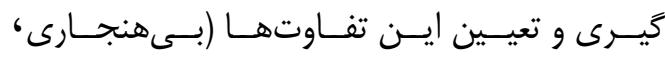

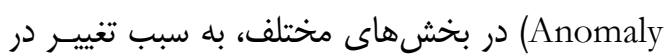
مقادير مورداندازهخيرى در يك محل به نسبت محيط

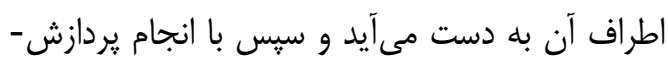

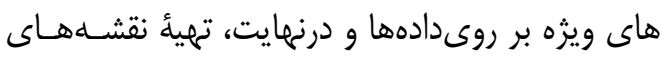

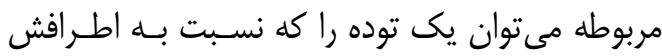

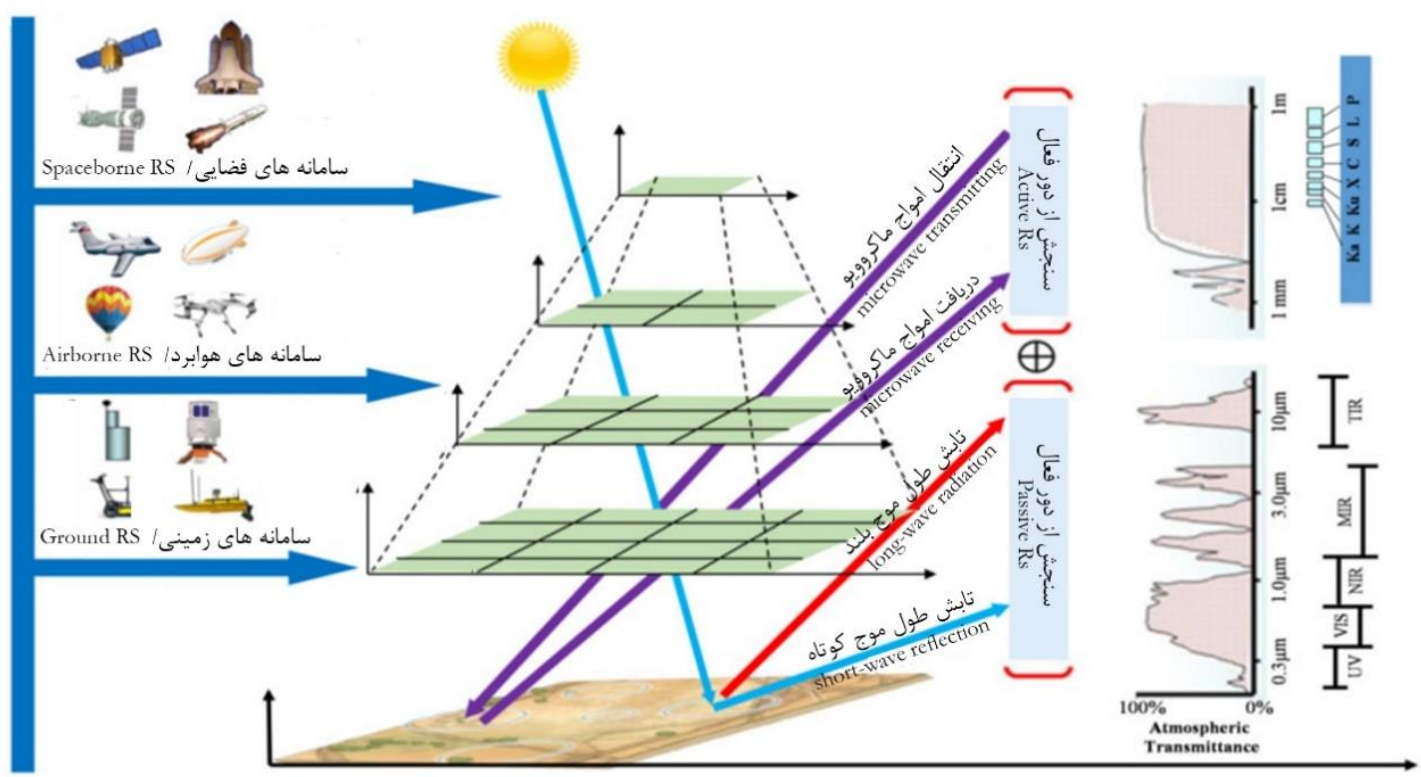

شكل V: شكل ترسيمى سامانههاى سنجشازدور براى كاربردهاى باستانشناسى و ميراث فرهنكى [75]

Fig.7: The schematic diagram of remote sensing for archaeological and cultural heritage applications 
سفال و ذوب فلز، تعيين محل و ضخامت خـاكهـاى

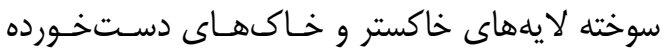

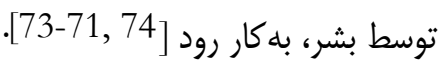
توجه به اين نكته حائز اهميت است كه اجراى صحيح

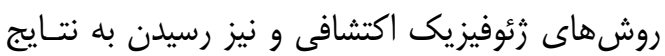
معتبر، مستلزم شرايط محيطى خاصى بـراى انــازه-

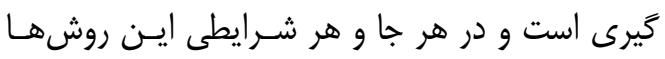

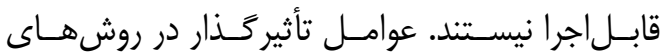

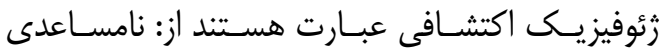

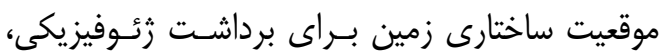

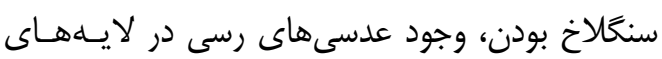
زيرين، نزديكى به سازههـاى فلـزى و سـاختمانهـا، نزديكى به خطوط انتقال نفت و كاز، سيمهاى تـورى

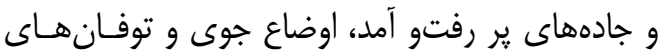
مغناطيسى و خورشـيدى. همجنـين محسدوديتهـاى

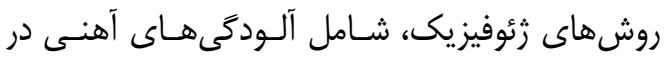

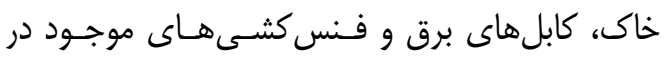

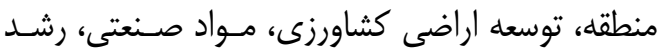

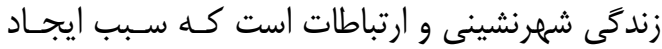

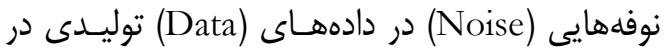
برخى از روشهـاى زئسوفيزيكى مسىشـوند [71-73] موارد فوق نشاندهندة تخصص در تفسـير دادههـاى اين كونه مطالعات است.

\section{Y-Y- حوزه مطالعاتى باستانز يستشناسى}

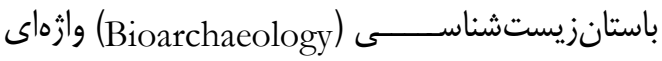

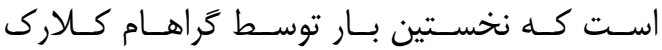

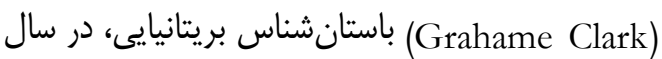

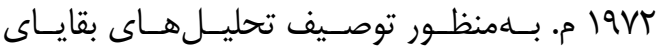

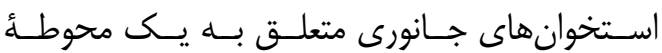
ييشازتاريخ بـهــار كَرفتـه شـــ [77-76]. امـا ايـن

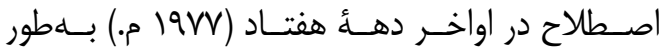

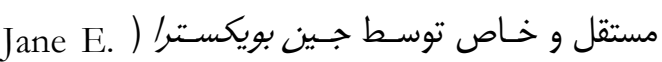
(Buikstra

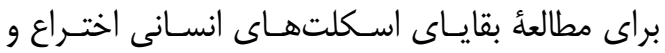

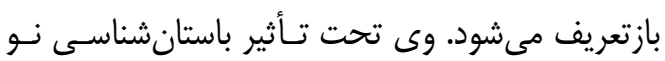

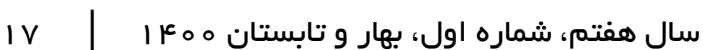

بلعاوه، جامعه باستانشناسان در دهأ هفتاد ميلادى

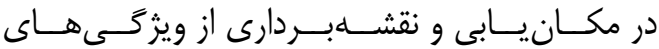

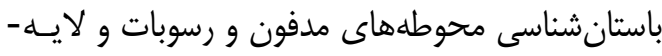
هــاى خـاك، متوجــه يتانسـيل اسـتفاده از روش رادار

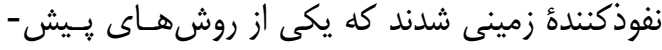

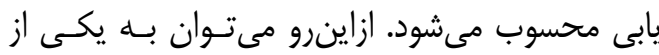
نخستين كاربردهاى آن در سال 19Va ميلادى بـراى تصويربردارى از ديوارهاى مدفون در عمق يكى متر، دران

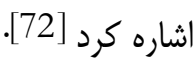

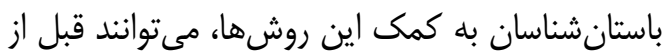
شروع به كاوش محل، براكندگى آثار مدفون را تعيين

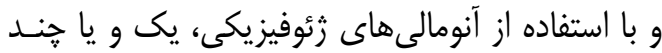

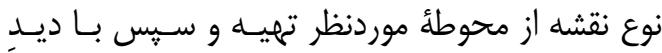

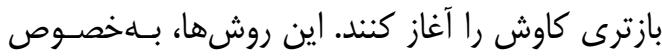
در مناطقى كه وجود آثار قابل ييشبينى است ولى بـ آسـه

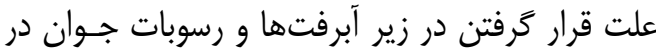

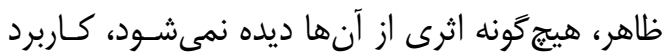

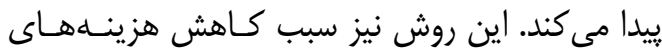

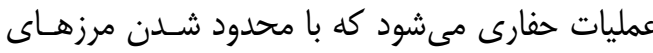

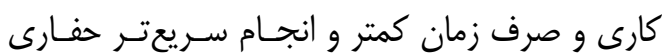
مىتوان به آن دستيافت و جستجوى باستانشناسان

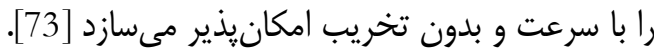

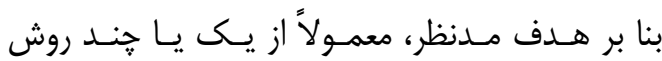

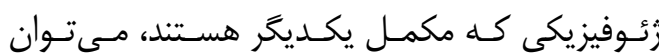
استفاده كرد كه منجر بــه افـزايش اعتبـار و اطمينـان

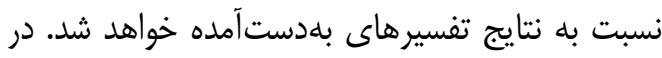

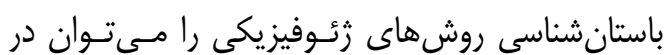
شناسايى و بازسازى ساختار معمارى مدفون در خاك، تعيين محل، اندازه و عمـق آثـار باسـتانى (تشـخيص مداري

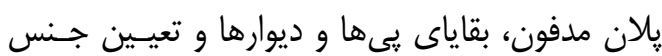

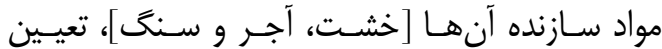

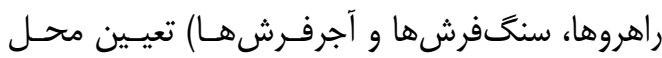

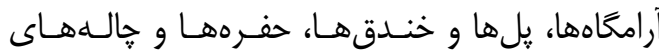
باستانى مربوط به ذخيره غذا يا دفع مواد زائد، تعيـين محل و ابعاد معادن باستانى و تعيين محل اجـاقهـا و دئا

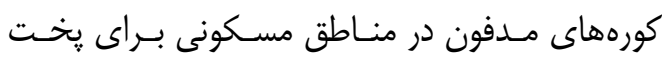




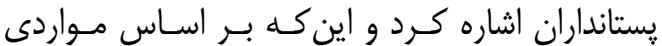

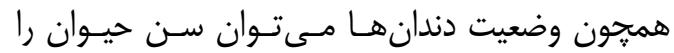

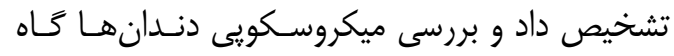
حتى محل ذبح حيوان را مشخص مى كنند. جمجمه و

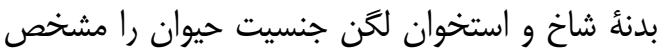

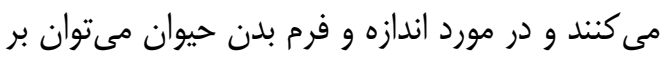

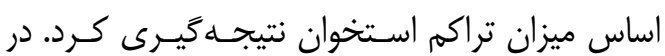

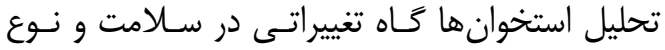

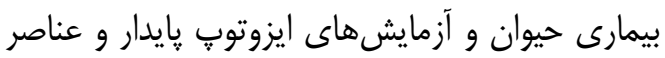

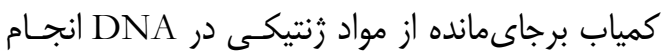

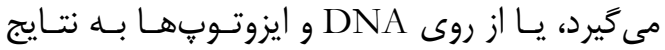

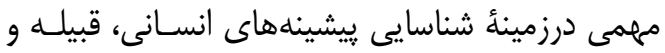

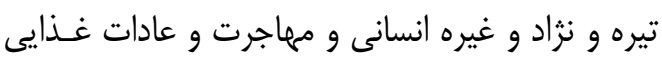
اقوام كهن مىتوان يـى بـرد [83]. از طرفسى اقلـيم و

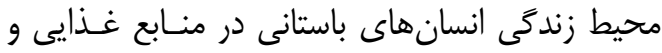

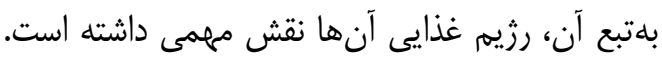
اين رابطه هم ازنظر نوع خاص گياهان و حيواناتى كه

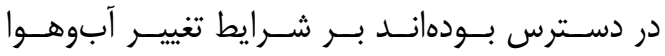
بلهمرورزمان و به دنبال آن، بر جمعيـت انسـان تـأثير

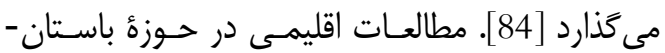

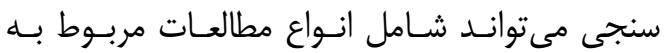

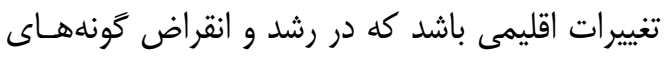

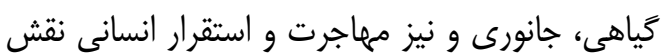

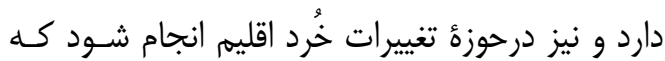

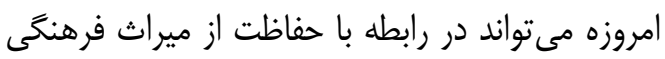
مؤثر باشد.

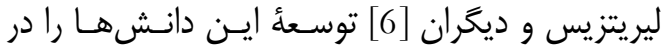
زمينأ علوم ميراث فرهنكى در دوشاخئ اصلى ديـرين

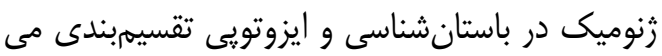
كند و در دستأ نخست كه مربوط به مطالعات زيست دئست موكولى است، از محورهايى همانند بررسى خاسـتخاهـ هاى انسانى، اهلى كردن جانوران و كَياهان، خاستخاه

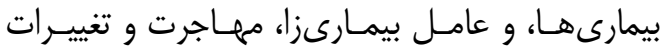
جمعيتـى و مطالعـات DNA باسـتانى و مطالعـات ايزوتـوبى اسـتخوانهــا و بقايـاى مولكـولى در اشـيا
قرار مى گيرد و طى مقالهاى به تعريف نوينى از زيست

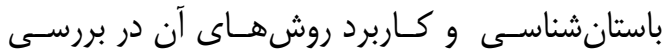
مشكلات باستان شناسى دست مى يابد [78]؛ بنـابراين

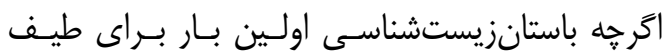

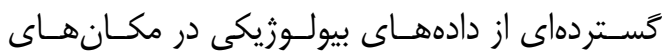
باستانشناسى كه مىتوانست از آنها بـراى بازسـازى دانى

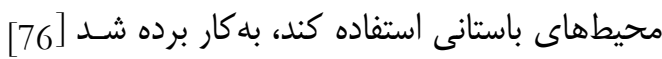

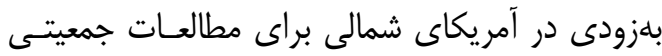

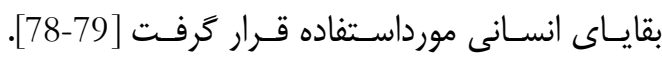

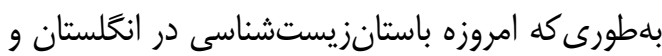
كشورهاى ارويايى، همجنان بلهنظور مطالعـأ بقايساى غيرانسانى شامل: جانورى، گياهى و بــاطور كلى تمـام

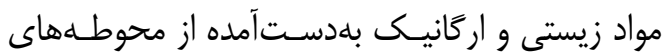
باستانى (باستان انخًلشناسى، مطالعه مدفوع و غيــره)

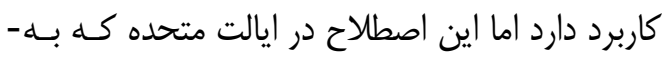

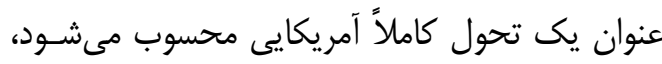
به مفهوم مطالعة بقاياى انسـانى اسـت [8

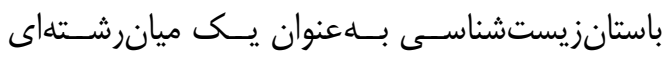

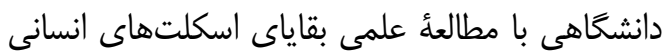

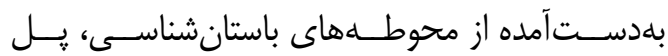

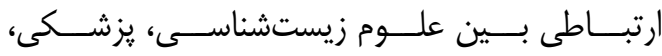

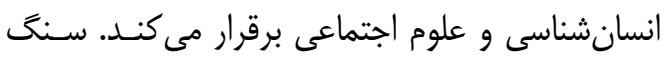
بناى باستانزيستشناسى، تعامل متقابل بين فرهنى

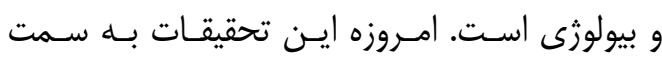

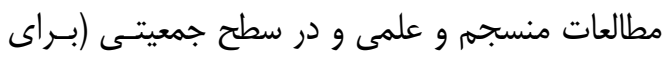

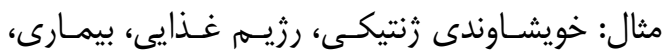

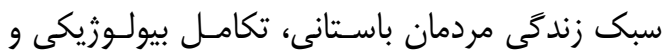

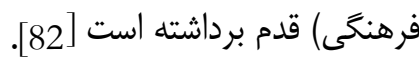
تحليل يافتههاى جانورى مانند استخوان، دندان، شاخ

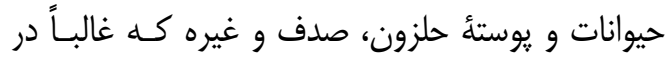

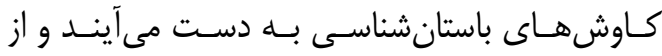

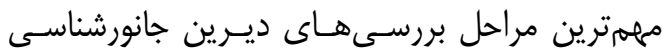

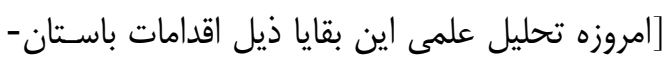
سنجى بوده] محسوب مى شود، تشخيص و طبقلهبندى إنى

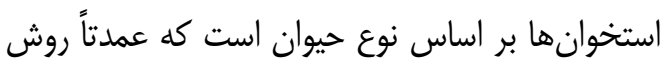

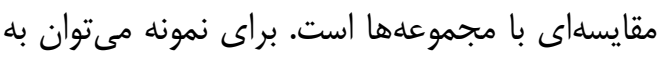


هاى استرانسيوم نشان داد، اهالى سـاكن / مـــفون در

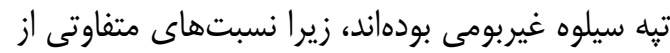

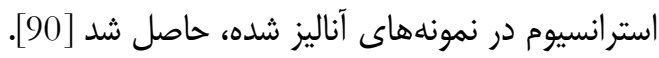

\section{1-ب. حوزة مطالعاتى باستانزمينشناسى و دير ين اقليمشناسى}

اصطلاح باستانزمينشناسى براى اولين بار در اوايـل

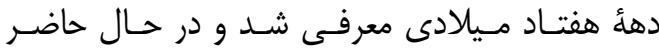

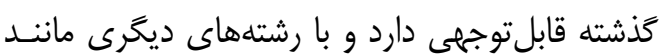

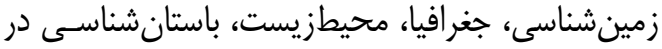

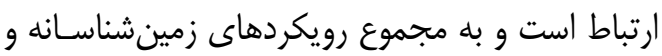

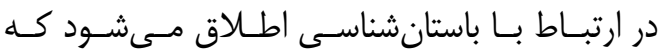
اطلاعاتى در مورد مناظر كذشتها، اقليم ديرينه، كياهان

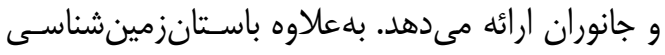

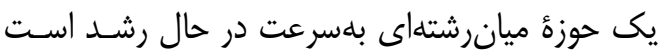

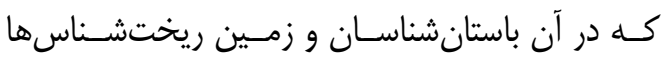

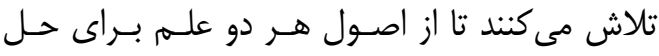

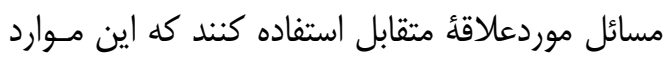
شامل استفاده از اصول ريختشناسى، رسوبكــارى، زمينشيمى ايزوتوب و سنحششناسى است. در تعبيـرى

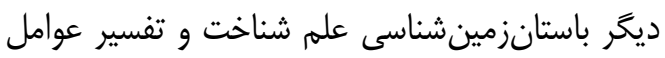

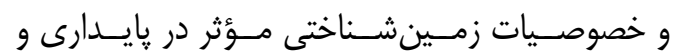
نإيايدارى [ميراث باستانى همانند] بناهـاى باسـتانى و و

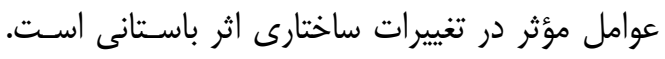
بلهعبارتديخر ساخت رزيهم زمينريختشناسى حـاكم بر منطقه نظير تأثير رودخانه، باد، سفره آب زيرزمينسى رئس

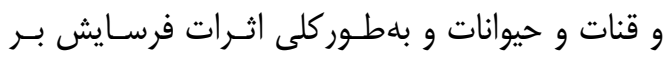
سازه و بررسى رزيم تكتونيكى و زمينسـاخت منطقـهـ فئه به قصد شناخت محيط دربركيرندة سـازنده و تحليـل

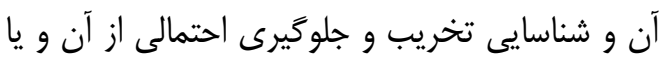

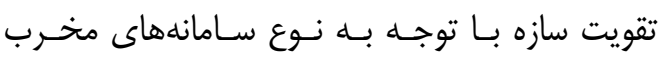

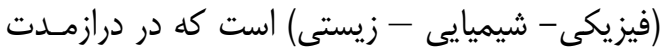

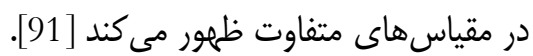

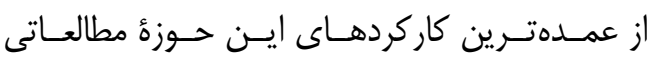

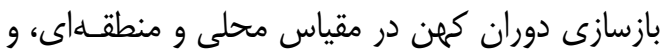
مناطق ديرينه اقليمى در مناطق مختلف جهان است.
باستانى و محتـواى مــواد غـــايى استفادهــــه اســت

مطالهـات ايزوتـويى بــه دليـلـ گَسـترهُ وسـيعى از موضوعاتى كه در برمى گيرد، زمينهُ تحقيقاتى در حال

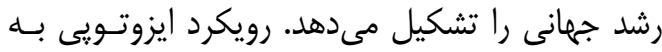

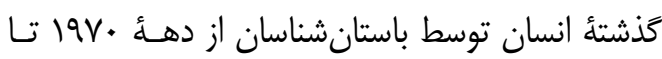

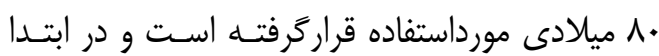

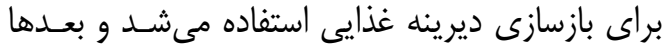

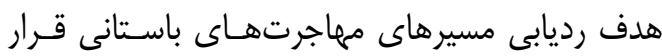

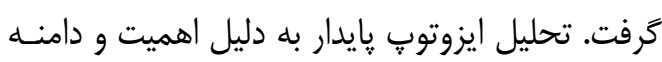

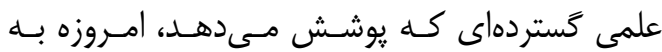

يكرشتأ فرعى براى خود تبديلشده است [6]

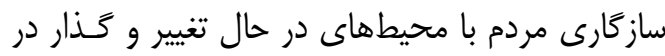

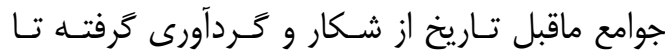

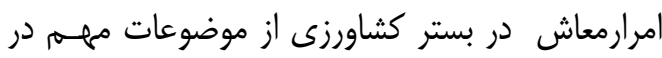

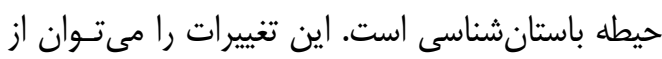

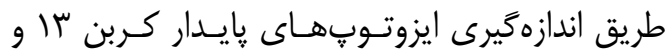
نيتروزن ها بهدست آمده از مواد اسكلتى و كياهـان و و

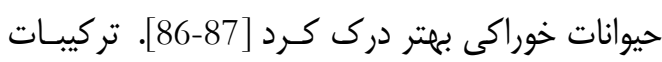

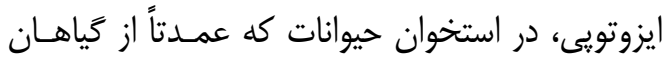
خاصى تتذيه مى كنند، استخوانهايى با تركيب مشابه

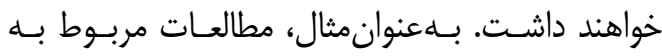

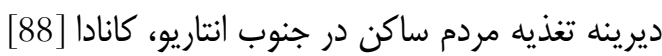

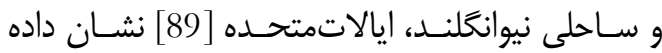

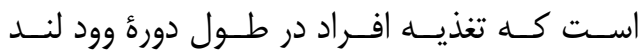

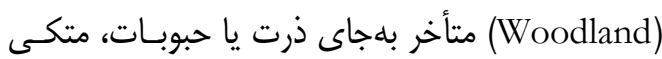
به يروتئينهاى حيوانى بوده است.

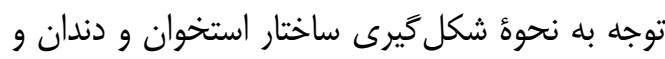

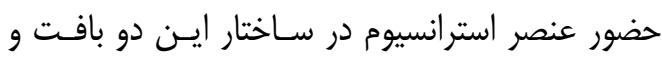

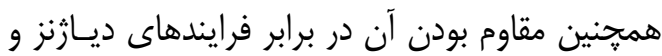

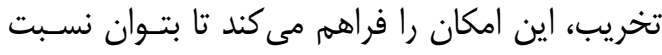

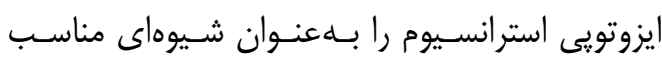
جهت بررسى مهاجرت در باستانشناسى معرفى كرد.

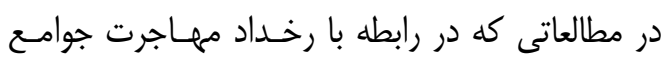

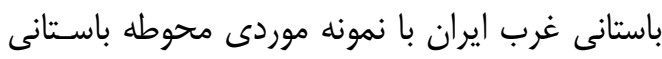

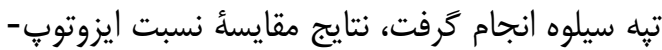


علل مختلف تغييرات زندگى اين جوامـع، مفيـد واقـع

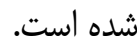

\section{q-". حوزه مطالعاتى سايبرباستانشناسى}

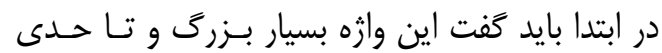
ناملموس است و نياز است تا جايكزين مناسبى هم در

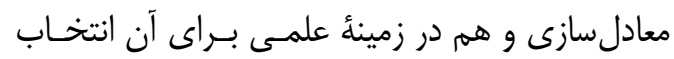

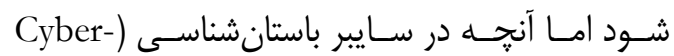
(Archaeology بيان مى شود درواقع يـــ مجموعـانها تركيبى و ييوندى ميان باستانشناسى، علـوم رايانسه،

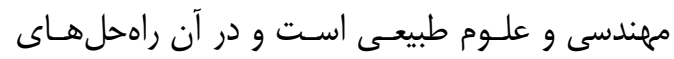

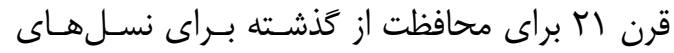

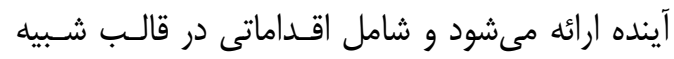

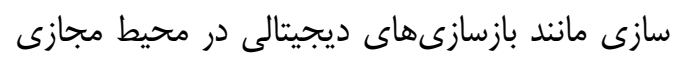

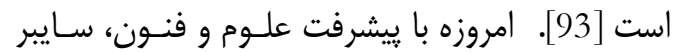

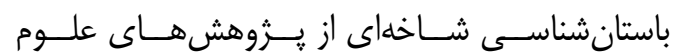

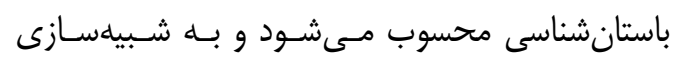
ديجيتالى اعصار كذشته مىيردازد. ديدكاه اين رشـته،

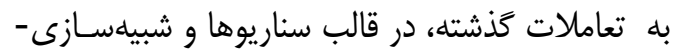

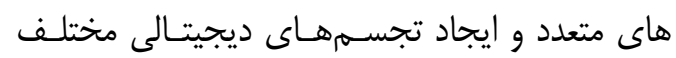

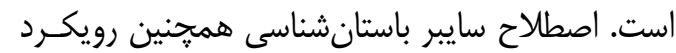

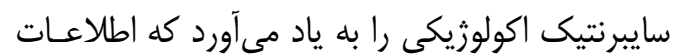

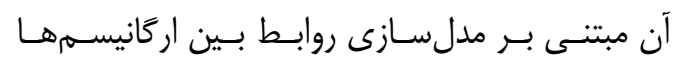

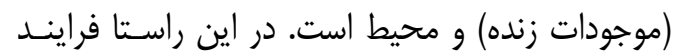

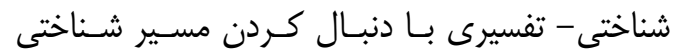

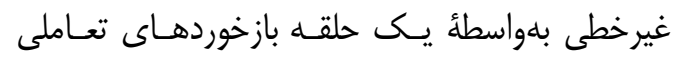
(ميان موجودات زنده و محيط) در بستر يـك محيط بـانيط

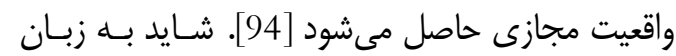

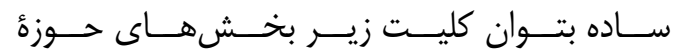

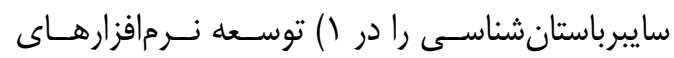

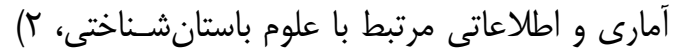

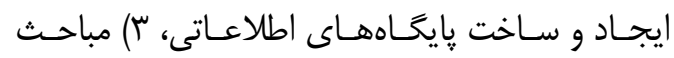

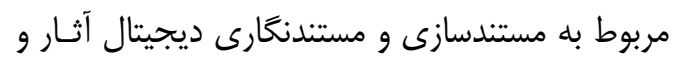

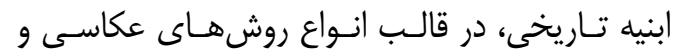

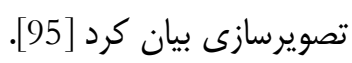

در ديرينه اقليمشناسى يا مطالعه اقليمهــاى كذشـته، دانشمندان ازآنجه بهعنوان دادههاى يروكسى شناخته

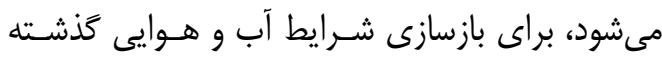

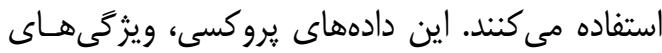
فيزيكى محيطزيست هسـتند. ديرينـه اقلـيممشناسـان

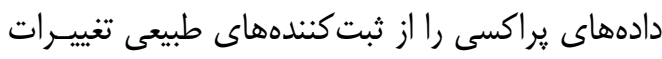

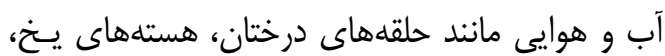

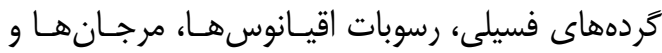

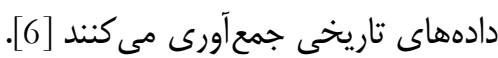

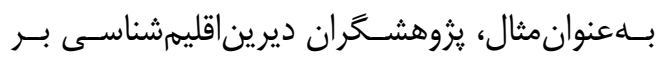

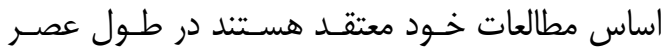
مفرغ در برخى محوطههاى شمال ايران، يـى افـول

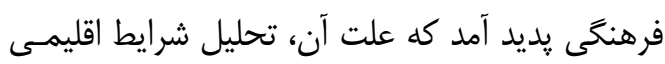

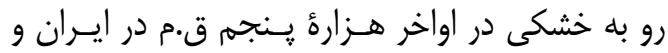

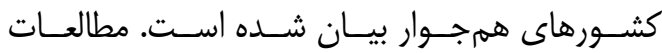

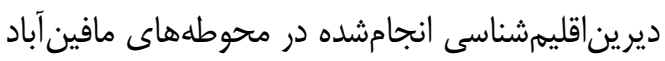

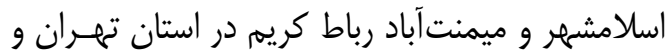
قرهتبه قمرود در استان قمه، بر اساس نتـايج مطالعـات

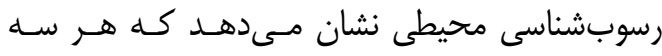
محوطه در اواسط و اواخر هـز ارهٔ جهـارم ق.م در اثـر

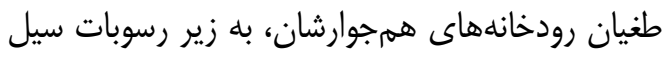

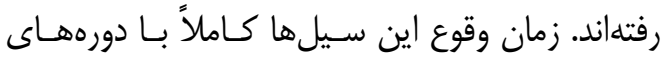

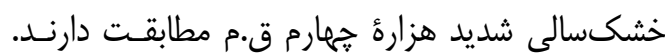
زيرا سيلهاى سهمخين ناشى از بارشهاى متمركز و

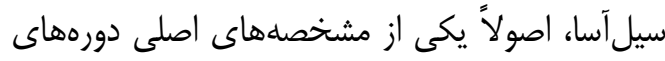

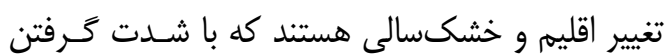

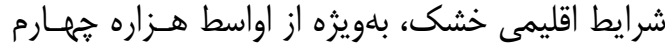
ق.م، جمعيت انسانى در منطقة فرهنكى شمال ايـران

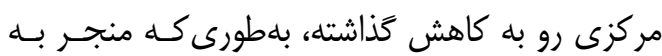
يك افول فرهنكى در عصر مفـرغ شـده اسـت [92]

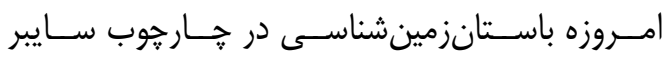
باستان شناسى توسعليافته است و تلفيق اين دو باهم، داسناسن در كنار آناليزهايى شيميايى- فيزيكى و لايهشناسىهـا

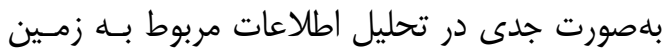

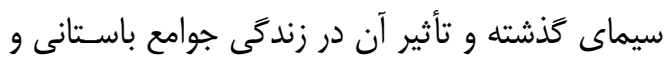


در اين زمينه مىتوان به مطالعاتى در كشور اشاره كرد

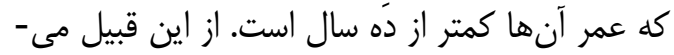

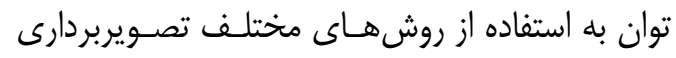

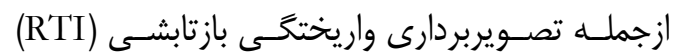
،97] (Reflectance Transformation Imaging) استفاده از فناورىهاى مرتبط با سلبعدى سازى بـراى

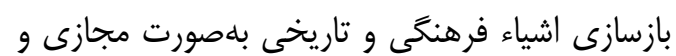

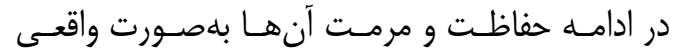

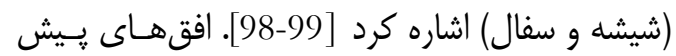

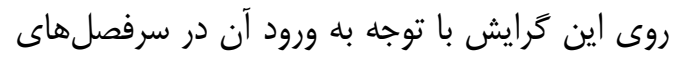
درسى دانشگاهى بسيار نويدبخش است
بهكار كَيرى فرايند فناورى اطلاعات ديجيتـال جهـت شبيهسازى، بازسازى و مديريت فراينـدهاى باسـتان -

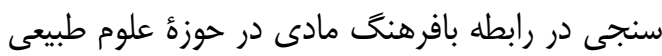

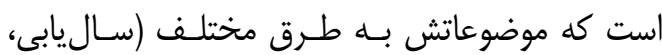

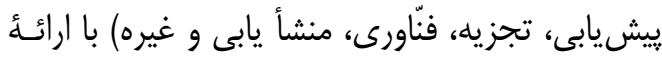

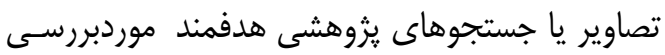

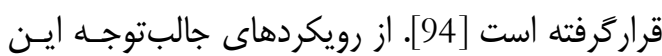

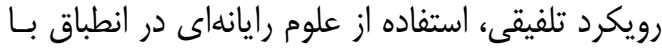

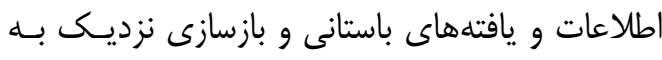

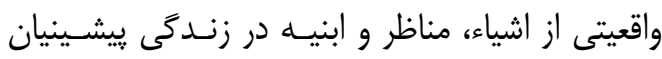
است [96] (شكل ^).

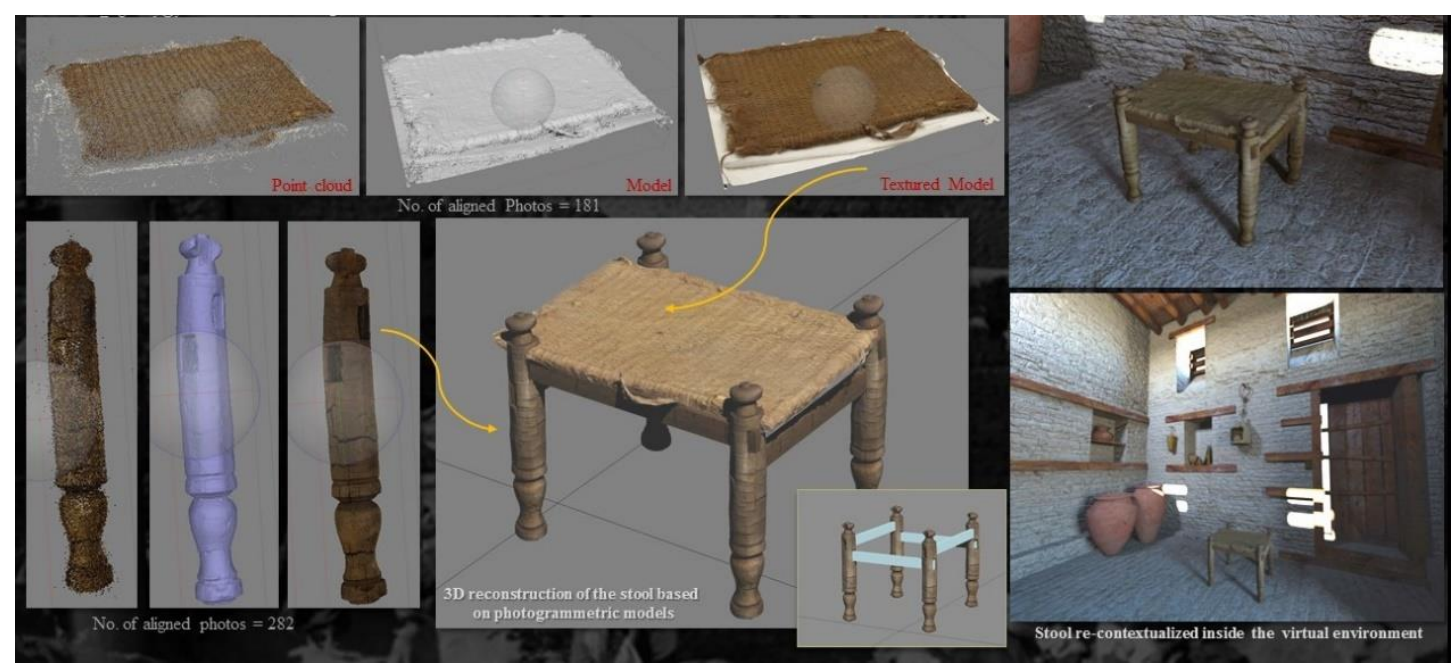

شكل ج: بازسازى سهبعدى قطعات مبلمان تاريخى از شهر كارانيس [96]

Fig. 8: 3D Reconstruction of Furniture Fragments from the Ancient Town of Karanis

مطالعات باستانسنجى و باستانســنجان را مشـخص

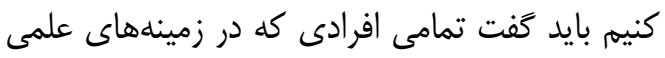

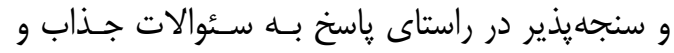

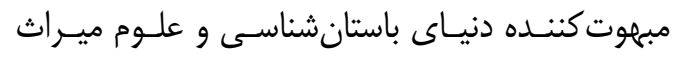

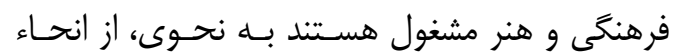

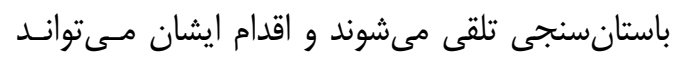
ذيل مفهوم باستانسنجى قرار كيرد.

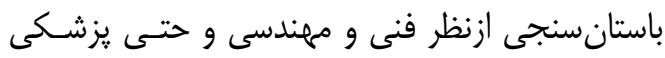

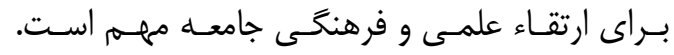

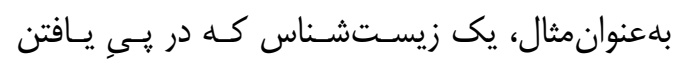

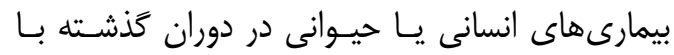

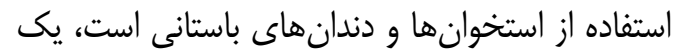

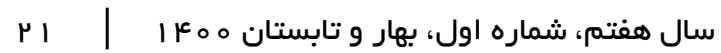

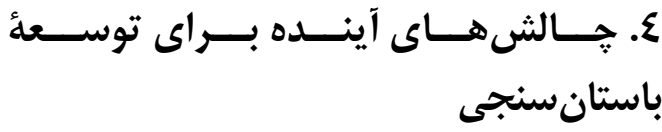

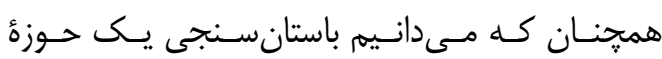

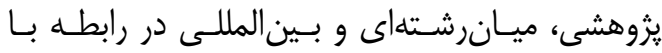

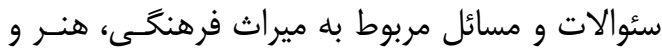

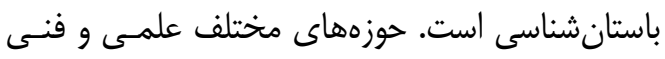
هستند كه همخام با رشد و توسعـل خـود، همخسى در

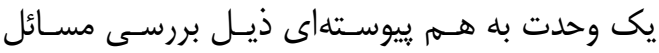

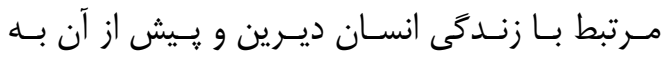
يزووهشهاى علمى در رابطه با موضـوعات ناشـناخته

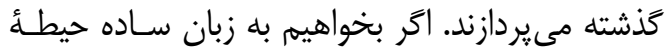


صنعت و رونق اقتصادى در اين عرصه اولين و شـايد مهمترين جالش توسعة اين رشتهٔ علمى است.

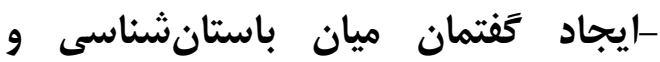
باستانسنجى: هنغامى كه يك باستانسنج نتايج

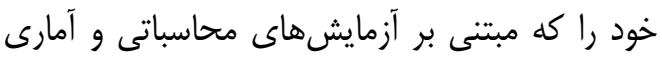

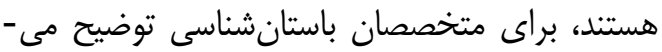

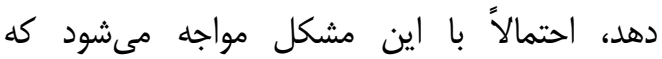

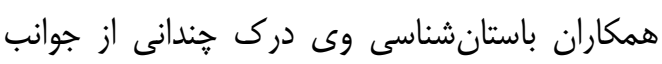
مختلف مطالب ارائهشده ندارند و اين شخص متران مىشود كه همكاران باستانشناسى او تنها علاقهمند

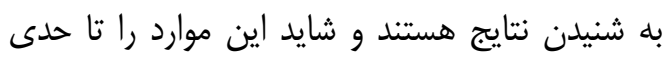
طفره رفتن از كفتن اصل ماجرا بيندارند. به احتمال

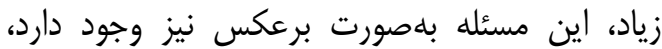

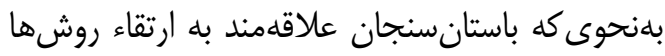
و مطالعات خود هستند اما آنها را از منظر سئوالات النات الناء برآمده از هنر و علوم انسانى نمىبينند، كه در اين

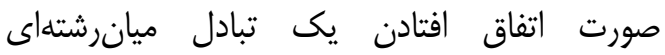

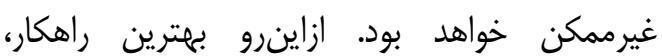
كذراندن واحدهاى درسى در رشتأ باستانسنجى براى

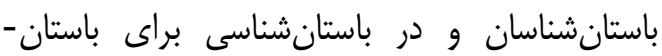

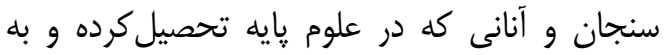
باستانسنجى واردشدهاند، است. تنها راهكار واقعى، دانى ايجاد كفتخو ميان اين دو قشر است تا بتوان به

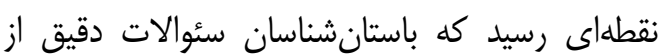
باستانسنجان بيرسند، سئوالهايى كه بر اساس باس

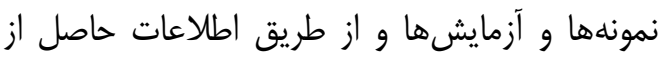

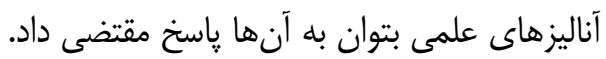

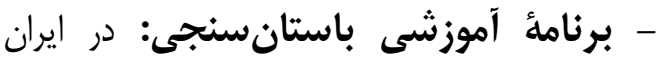
همانند كشورهاى ارويايى نيز باستانسنجى در مقاطع إنى تحصيلات تكميلى در برنامئ آموزشى دانشعامهاهيا

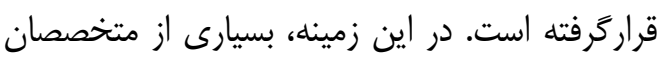

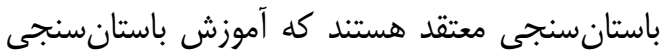
بايد متمركز بر روى افرادى شود كه در علوم پائه

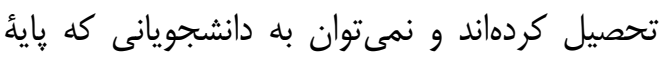

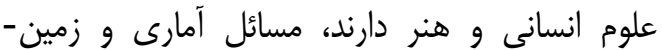
شناسى و شناخت مواد را در طى مدت كوتاه
اقدام سراسر باستانسنجانه انجام مــدهـــ، زيــرا بــرـ

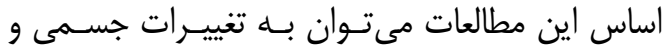

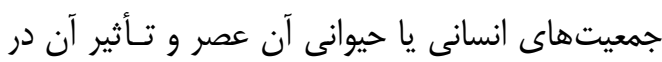

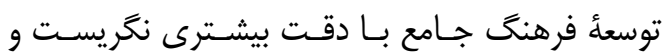

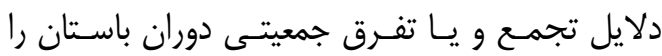

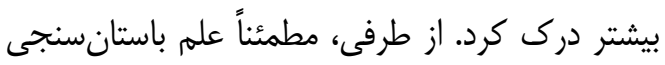

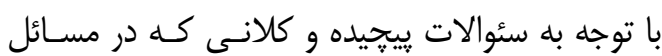

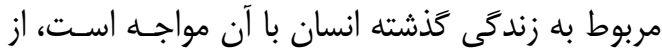

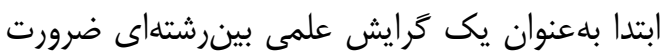
انجام و توسعةُ بيشتر مطالعات ميانرشتهاى رائ را در خود نهادينه كرده است. زيرا اين مطالعات بينرشتهاى هم

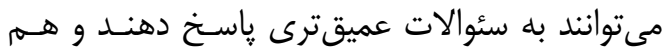

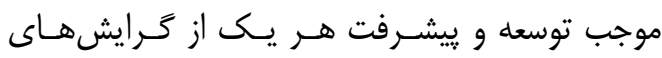

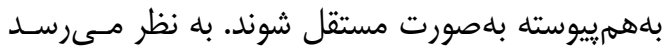

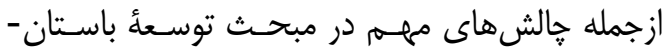
سنجى كه بايد يزوهشگران اين حوزه بهصورت جدى آنها را يِيخيرى كنند عبارت هستند ازي

\section{-تخصـيص ســرمايه در مطالعــات ميـراث}

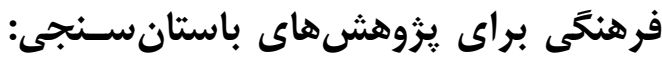

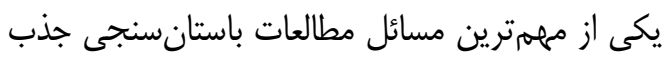

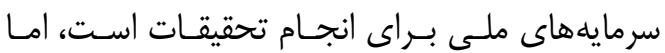
ازأنجاكه مطالهـات باسـتانسـنجى در فضـائى ميـان رشتخى بين حوزههاى تاريخى و فرهنكى با اقدامات دات

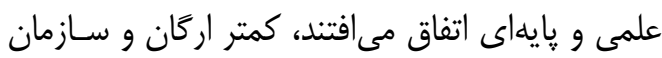
و صاحبان سرمايهاى را مىتوان براى تأمين بودجهاى

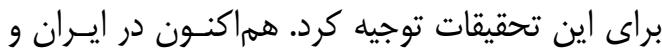
اقصا نقاط جهان، علاقه به مطالعات باستانسنجى در درد ميان باستانشناسان بسيار فراوان شده است، اما تقريباً

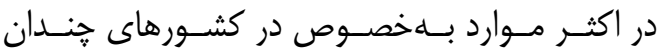

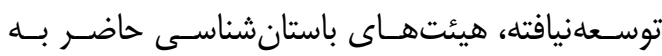

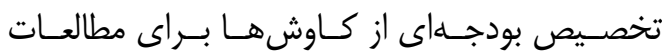

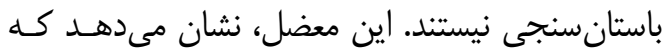

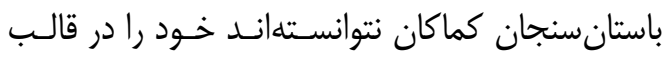

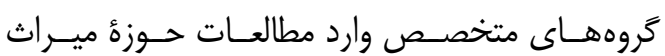
فرهنگى و باستانشناسى كنند. ازاينرو ايجاد ارتباط با 
پايخاه يزوهشى ياسار كاد نمونـهـهـاى مطالعـات قبلى

نمجهدارى نمى شوند.

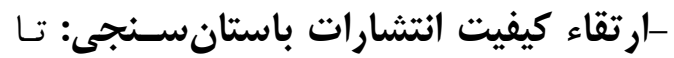
جند سـال قبـل و همماكنـون در بسـيارى از مجـاءلات

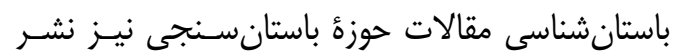

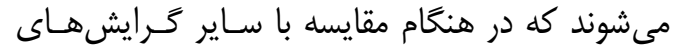

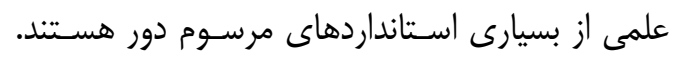

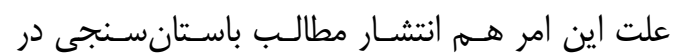

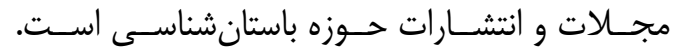

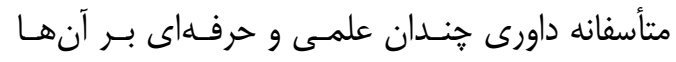

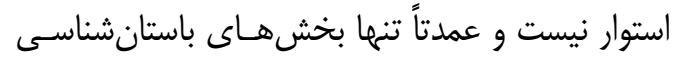
از ديد باستانشناسان موردانتقاد اندكى قرار مى يَيرد و

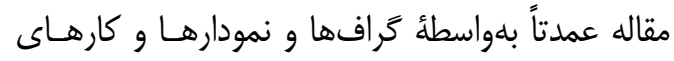

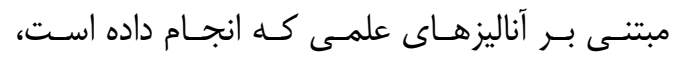

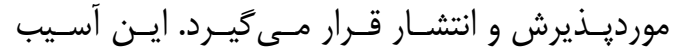

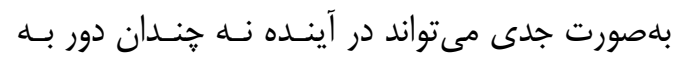

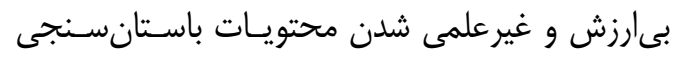
مجلات باستانشناسى در نزد متخصصان بينجامد.

\section{0. نتيجهلَيرى}

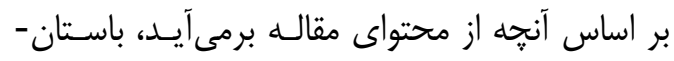
سنجان در رابطه با سـئوالات دنيـاى باسـتان، نتـايج

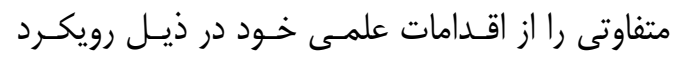
باستان سنجى به جامعه ارائه مىدهند. مطالعات ايشان كاه در خدمت اهــداف سياسـى قـرار مى گيــرد و كَاه اهداف اقتصادى حمايت كننده از اين قبيـل مطالعـات

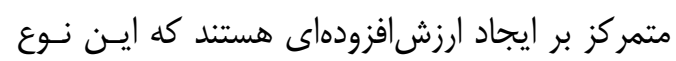

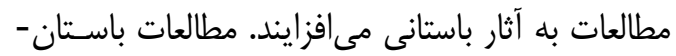

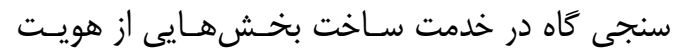

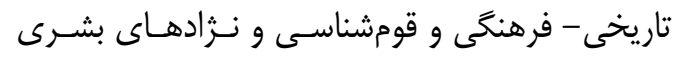

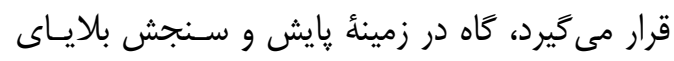
مخرب و ارزيابى فرايندهاى درمانى براى آثار و ابنيــ

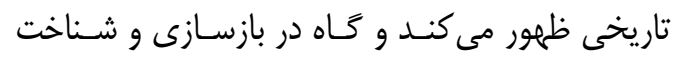
مصالح و مواد تشـكيل دهنده، كـاربرى و منشـأ اشـيا

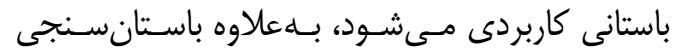

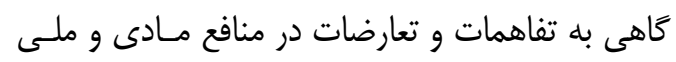

تحصيلات تكميلى آموزش داد، بلطورى كه در آينده بتوانند در اين زمينه فعاليت كنند. حال، سئوال اينجا

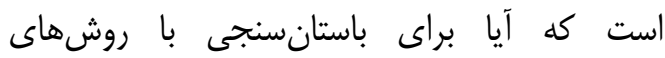
اينجنينى مانند يذيرش دانشجو و ضعف در منابع

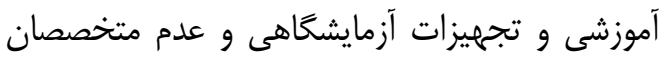

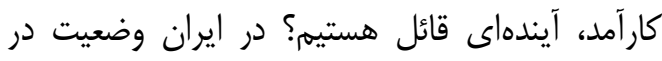

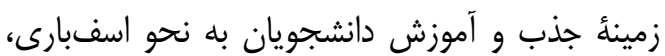
وخيم است. زيرا رشتهُ باستانسنجى در مئن ميان دانشجويان و متخصصان علوم بايه و فنى ناشناخت ناخته است و از طرفى با جذب دانشجويان از طريق كنكور

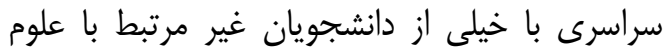
يايه و فنى در دانشكاههاى كشور مواجه هستيم كه

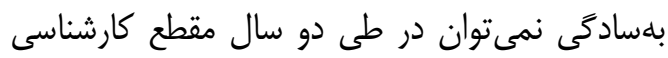

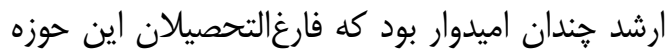

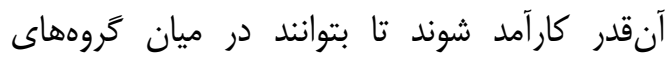
باستان شناسى جايى را بلعنوان باستانسنج براى بار خود

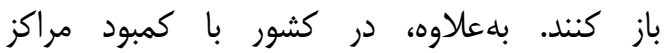
آزمايشگاهى تحقيقاتى مواجه هستيم كه اين امر باز

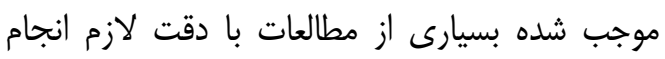

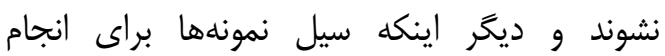
مطالعات به آزمايشكاههاى معتبر خارجى روانه شوند.

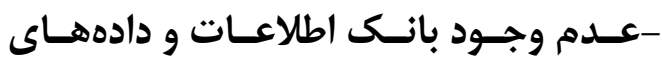
باستان سنجىى: عدم وجود بانكى اطلاعـات و داده-

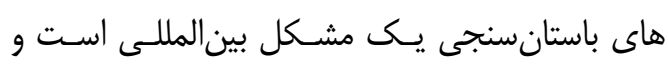
بسيارى از كشورهاى مشتركالمنافع به فكر ايجاد آن بن بان

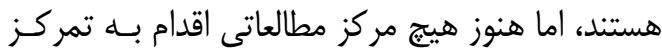
بخشى و كردآورى بانك اطلاعات مربوط به انتشارات

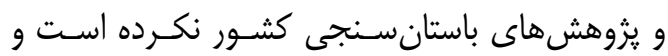

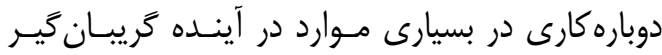

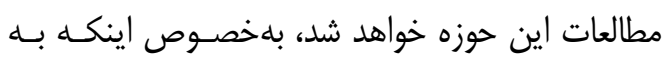

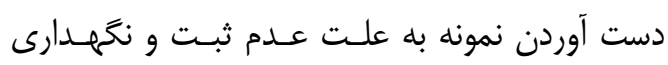

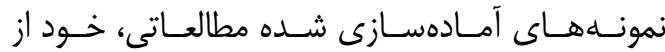
مشكلات جدى اين حوزه است. بلنحوى كـهـ مـثلاً در

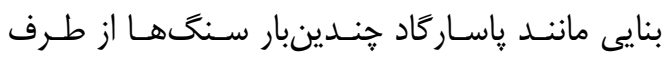
متخصصان مختلف شناسايىشده امـا بـار ديخـر اخر

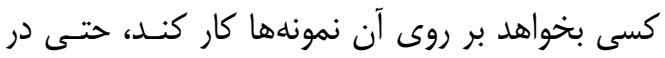




\section{يبى نوشت ها}

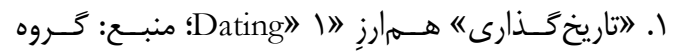

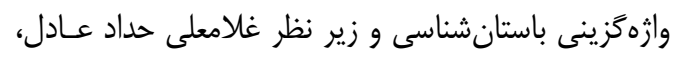

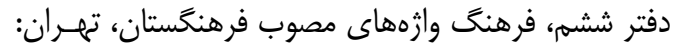

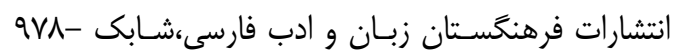

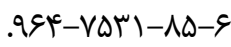

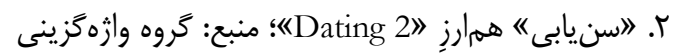

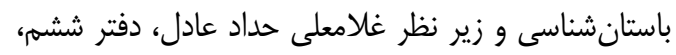

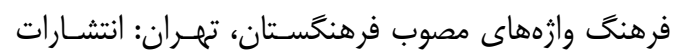

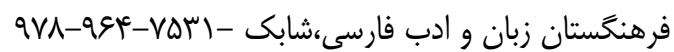

س. ليدار (LIDAR) يك فتّاورى سـنجش از راه دور اسـت

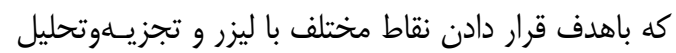

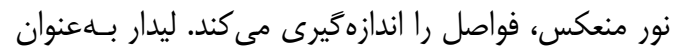

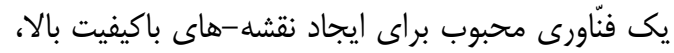

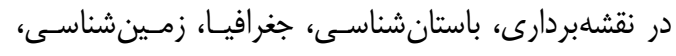

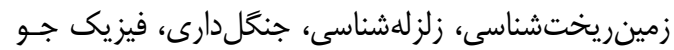

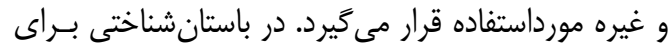
يثوهشهاى بررسى و الكَوهاى استقرارى از إيـن روش

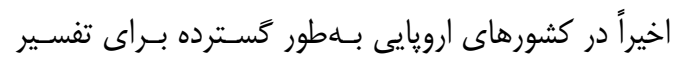
منظر تاريخى استفاده مى أشود [VN].

\section{References}

[1] Pollard AM, Batt CM, Stern B, Young SM, Young SM. Analytical chemistry in archaeology. Cambridge University Press; 2007.

[2] Tite MS. Archaeometry-an overview. Inproceedings-International School of Physics Enrico Fermi 2004;154: p. 347-356. IOS Press; Ohmsha; 1999.

[3] Stern WB. Archaeometry-Analyzing the Cultural Heritage. CHIMIA International Journal for Chemistry. 2001 Nov 1;55(11): p.915-22.

[4] Bahrololoumi, F., Bahadori R., Archaeometry in archaeological

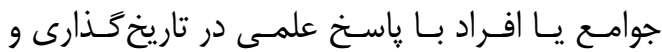

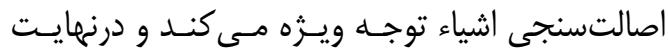

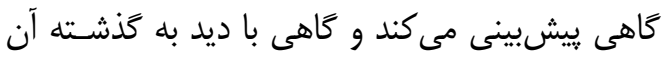

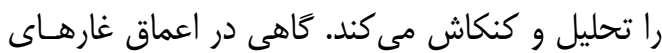
ماقبل تاريخ و لايههاى ديرين زمينشناسى كنكـاش كناش

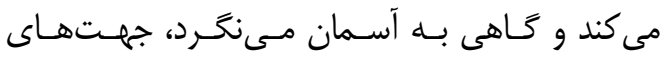

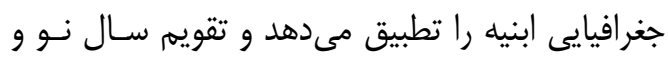

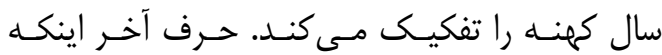

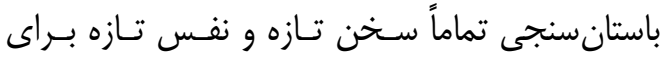

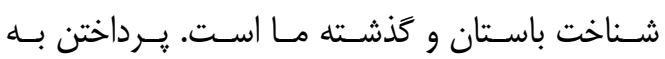

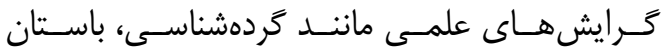
استخوان شناسى، باستان حيوان شناسى، باستان كيـاهـ

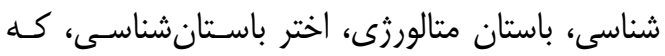

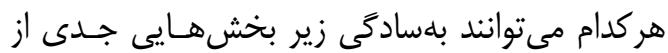

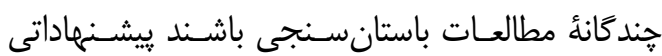

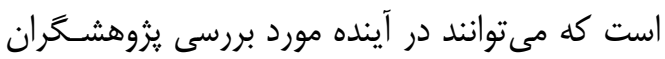

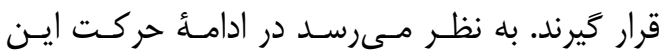
كرايش يزوهشى، تدوين اخلاق باستانسنجى از تام هاى بعدى توسعة آن باشد. تلخدي

\section{سياسگزارى}

بدين وسيله از دانشخاه هنر اسلامى تبريز كـه بـا در اختيار نهادن امكانات مادى و معنـوى موجـب انجـام اين تحقيق شد، سياسخزارى مىشود.

research in Iran, Eighty Years of Iranian Archaeology, Vol. 2, Editors: Yousef Hassanzadehy; Sima Miri: Pazineh Press Center \& National Museum of Iran. 2012.pp329-344

[بحر العلومى، فرانـى، بهـادرى. رويـا. نقـش باسـتان

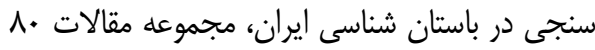

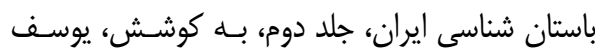

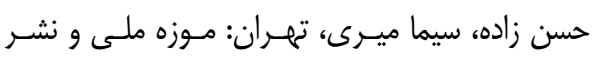

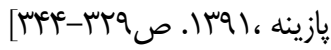

[5] Razani M, Ajourlou B (edited). Introduction to the book Application of Scientific Analysis in Archeology and Restoration of Cultural Heritage, 
Selected Articles of the First and Second National Conferences. editors: Razani M, Ajourlou B. Tabriz: Islamic Art University of Tabriz (1391-1392) 1393. [in Persian]

[رازانى مهدى، آجورلو بهـرام (بــهـ ويـرايش). مقدمـهـ

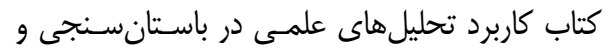

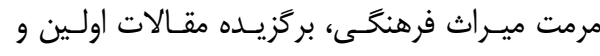

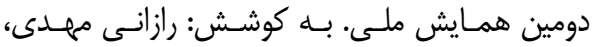

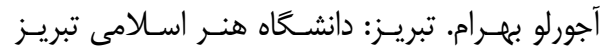
[.

[6] Liritzis I, Laskaris N, Vafiadou A, Karapanagiotis I, Volonakis P, Papageorgopoulou C, Bratitsi M. Archaeometry: an overview. Scientific Culture. 2020 Jan 1;6(1):49-99.

[7] Pollard AM. Archaeometry 50th anniversary issue editorial. Archaeometry. 2008 Apr;50(2):191-3.

[8] Archaeometry. (1981). Walter Sullivan, New York Times, from https://www.merriam-webster.com/ dictionary/ archaeometry.

[9] Archaeometry. (1958), from https://www.merriamwebster.com/dictionary/ archaeometry.

[10] Archaeometry. (n.d). Retrieved November 9, 2018, from https://ahdictionary.com/word/searc h.html?q=archaeometry

[11] Archaeometry.. (n.d). Retrieved November 9, 2018, from, https://www.collinsdictionary.com/ dictionary/english/archaeometry

[12] Ehrenreich RM. Archaeometry into archaeology. Journal of Archaeological Method and Theory. 1995 Mar 1: p.16.

[13] Martini M, Piacentini M, editors. Physics methods in archaeometry. IOS press; 2004 Jun 9.

[14]Jones A. Archaeometry and materiality: materials based analysis in theory and practice. Archaeometry. 2004 Aug;46(3): p. 327-38.

[15] Darvill,

T. (2008). archaeometry. In The

Concise Oxford Dictionary of
Archaeology: Oxford University Press. Retrieved 31 Jul. 2019, from https://www.oxfordreference.com/vi ew/10.1093/acref/9780199534043.00 $1.0001 /$ acref $9780199534043-$-e36.

[16] Glascock MD. Archaeometry. Encyclopedia of Global Archaeology, ed. by Deborah M. Pearsall. Academic Press, New York. 2008

[17] Artioli G, Angelini I. Scientific methods and cultural heritage: an introduction to the application of materials science to archaeometry and conservation science. Oxford University Press; 2010 Jul 8.

[18] Martinón-Torres M, Killick D. Archaeological theories and archaeological sciences. InThe Oxford Handbook of Archaeological Theory 2015.

[19] Bahrololumi Shapoor Abadi, F. Dating methods in archeology. Tehran: 1388. [in Persian]

$$
\begin{aligned}
& \text { [بحر العلومى شايورآبادى فرانك. روشهاى ساليابى }
\end{aligned}
$$

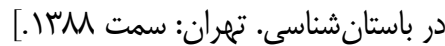

[20] Holmes A. The association of lead with uranium in rock-minerals, and its application to the measurement of geological time. Proceedings of the Royal Society of London. Series A, Containing Papers of a Mathematical and Physical Character. 1911 Jun 9;85(578): p.248-56.

[21] Taylor RE, Aitken MJ, editors. Chronometric dating in archaeology. Springer Science \& Business Media; 1997 Nov 30

[22] Adams WY, Adams EW, Adams EW, Adams EW, Mathematician P. Archaeological typology and practical reality: a dialectical approach to artifact classification and sorting. Cambridge: Cambridge University Press; 1991.

[23] Baillie MG. Tree-ring dating and archaeology. Routledge; 2014 Oct 24.

[24] Aitken MJ. Science-based Dating in Archaeology, Longman. London. Allen, JRL Coal dust in the Severn Estuary, southwestern UK. Marine Pollution Bulletin. 1990;18: p.169-74.

[25] Rixhon G, Briant RM, Cordier S, Duval M, Jones A, Scholz D. 
Revealing the pace of river landscape evolution during the Quaternary: recent developments in numerical dating methods. Quaternary Science Reviews. 2017 Jun 15; 166: p.91-113.

[26] Walker M. Quaternary dating methods. John Wiley and Sons; 2005 Jun 17.

[27] Tite MS. Archaeological Science-Past Achievements and Future Prospects. Archaeometry. 1991 Aug;33(2): p.13951.

[28] Bahrololumi Shapoor Abadi, F. Archeometry, a way for communication between the natural sciences and archeology. Physics day. 2014; 5: p.32-37. [in Persian]

$$
\begin{aligned}
& \text { [بحر العلومى شايورآبادى فرانك. باسـتانسـنجى، راه :32: }
\end{aligned}
$$

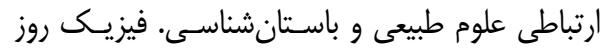

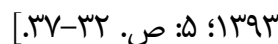

[29] Emami M, Razani M, Soleimani NA, Madjidzadeh Y. New insights into the characterization and provenance of chlorite objects from the Jiroft civilization in Iran. Journal of Archaeological Science: Reports. 2017 Dec 1;16: p.194-204.

[30] Nagel A. "Persepolis in Color" in In Tehran 50: ein halbes Jahrhundert deutsche Archäologen in Iran; eine Ausstellung des Deutschen Archäologischen Instituts in Zusammenarbeit mit dem Museum für Islamische Kunst, by: EurasienAbteilung Deutsches Archäologisches Institut. Staatliche Museen Berlin;2. 12. 2011-4. 3. 2012, Translated in Persianby B, Rahimipour P. Translated by Fahimi. H. Translated by Fahimi $\mathrm{H}$. Tehran: National Museum of Iran 2016. p.229-231. [in Persian]

$$
\begin{aligned}
& \text { [ناگل الكساندر. ״تخت جمشيد رنخىى" در تهران •ه؛ }
\end{aligned}
$$

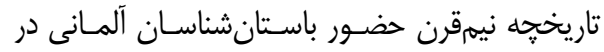

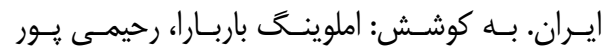

$$
\begin{aligned}
& \text { ״اتريسيا. ترجمه فهيمى حميد. ناشر: موزه ملى ايـران. }
\end{aligned}
$$

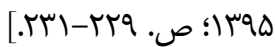

[31] Dadashzadeh M, Gorji M, Vahidzadeh R. "Egyptian Blue" or "Lapis Lazuli Paste"? Structural Study and Identification of the Collection of the Objects Nominate Lapis Lazuli Paste in the National Museum of Iran. Journal of Research on Archaeometry. 2017 Mar 10; 2(2): p.35-48. [Original in Persian with English Abstract]

$$
\begin{aligned}
& \text { زداداش زاده مارال، عبداله خان گرجى مهنـاز، وحيــ }
\end{aligned}
$$

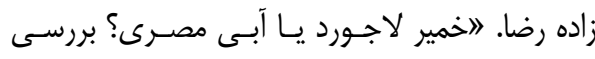

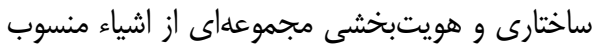

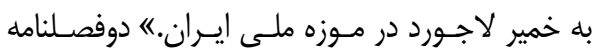

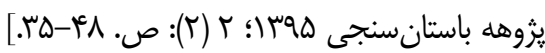

[32] Price TD, Burton JH. Provenience and Provenance. InAn Introduction to Archaeological Chemistry.Springer, New York, NY.2011: p. 213-42.

[33] Quinn PS. Ceramic petrography. The interpretation of archaeological pottery and related artefacts in thin section: Oxford, Archaeopress. 2013.

[34] Kasiri MB, Shahrsabzi S, Emami M, Razani M. Provenance of the stones used in plinths of the Achaemenid palaces of Borazjan, South-Western of Iran. Journal of Archaeological Science: Reports. 2020 Feb 1; 29:102064.

[35] Emami M, Eslami M, Fadaei $H$, Karami HR, Ahmadi K. Mineralogical-geochemical characterization and provenance of the stones used at the Pasargadae Complex in Iran: A new perspective. Archaeometry. 2018 Dec;60(6): p.1184-201.

[36] Kohl PL, Harbottle G, Sayre EV. Physical and chemical analysis of soft stone vessels from southwest Asia. Archaeometry. 1979 Jan 1;21(2): p.131-59.

[37] Abedi A, Vosough B, Razani M, Kasiri MB, Steiniger D, Ebrahimi G. Obsidian Deposits From NorthWestern Iran and First Analytical Results: Implications for Prehistoric Production and Trade. Mediterranean Archaeology \& Archaeometry. 2018 Apr 1;18(2).

[38] Price CA, Doehne E. Stone conservation: an overview of current research. Getty publications; $2011 \mathrm{Feb}$ 15.

[39] Henderson J, Evans JA, Sloane HJ, Leng MJ, Doherty C. The use of oxygen, strontium and lead isotopes to 
provenance ancient glasses in the Middle East. Journal of Archaeological Science. 2005 May 1;32(5):665-73.

[40] Roberts BW, Thornton CP, editors. Archaeometallurgy in global perspective: methods and syntheses. Springer Science \& Business Media; 2014 Jan 7

[41] Pernicka E. Provenance determination of archaeological metal objects. In Archaeometallurgy in global perspective Roberts BW, Thornton CP, editors 2014 (pp. 239-268). . Science \& Business Media Springer, New York, NY.

[42] Razani M, Nasirzadeh B. Fake and Forgery in Antiquities and Visual Arts: Terminology, Typology, Legal Fate and Evaluation Methods " Proceedings of the 1 st \& 2nd Iranian National Symposium on the Application of Scientific Analyses in Archaeometry and the Conservation of Cultural Heritage 2012 \& 2013Editors: Mehdi Razani \& Bahram, T IAU, Vol 1-2 (2012-2013) 2014; p. 32-107. [in Persian]

$$
\begin{aligned}
& \text { [رازانى مهلىى، نصير زاده بهناز. جعل و تقلـب در آثـار }
\end{aligned}
$$

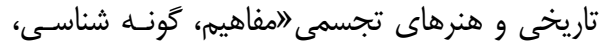

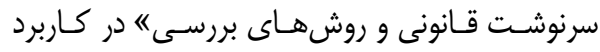

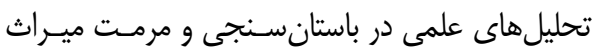

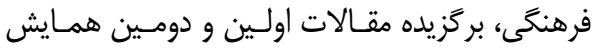

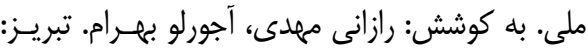

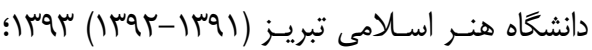

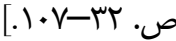

[43] Feilden BM, Jokilehto J. Management guidelines for world cultural heritage sites. 1998.

[44] Holtorf C, Schadla-Hall T. Age as artefact: on archaeological authenticity. European journal of archaeology. 1999;2(2): p.229-47

[45] Labadi S. World Heritage, authenticity and post-authenticity: international and national perspectives. InHeritage and globalization. Routledge. 2010 Jun 17; p. 80-98.

[46] Petzet M. International principles of preservation. Monuments and Sites. 2009;20.
[47] Scott DA. Art: Authenticity, Restoration, Forgery. ISD LLC; 2016 Dec 31.

[48] Korff G, Roth M, editors. Das Historische Museum. Campus Verlag; 1990.

[49] Seidenspinner W. Authentizität. Kulturanthropologischerinnerungskundliche Annäherungen an ein zentrales Wissenschaftskonzeptim Blick auf das Weltkulturerbe. 2007.

[50] Craddock P. Scientific Investigation of Copies. Fakes and Forgeries (Ljubljana: Elsevier Ltd., 2009). 2009: p.141-60.

[51] Tite MS. Archaeological Science-Past Achievements and Future Prospects. Archaeometry. 1991 Aug;33(2): p.13951.

[52] Heeb J, Ottaway BS. Experimental archaeometallurgy.

InArchaeometallurgy in global perspective. Springer, New York, NY. 2014; p. 161-92.

[53] Renfrew C, Bahn P, editors. Archaeology: the key concepts (pp. 1523). Routledge; 2013 Sep 5.

[54] Ascher R. Experimental archeology. American Anthropologist. 1961 Aug 1:793-816.

[55] Coles J. Archaeology by experiment. Routledge; 2014 Oct 24.

[56] Reynolds PJ. The nature of experiment in archaeology. Experiment and design: Archaeological studies in honour of John Coles. 1999 Oct: p.156-62.

[57] Mathieu JR. Experimental archaeology. BAR International Series. 2002;1035.

[58] Kingery WD. Technological systems and some implications with regard to continuity and change. History from things: Essays on material culture. 1993 Apr 17: p.215-30.

[59] Franklin U. The real world of technology. CBC Massey Lecture Series.1992.

[60] Miller HM. Chapter 2: Methodology: Archaeological Approaches to the Study of Technology. Archaeological 
Approaches to Technology. 2007; p.13-39.

[61] Price TD, Burton JH. Technology, Function, and Human Activity. InAn Introduction to Archaeological Chemistry 2011 (pp. 155-186). Springer, New York, NY.

[62] Emami SM. Archaeometry, a Discipline for Linking Archaeology to Natural Sciences (Aims and Scopes). Journal of Research on Archaeometry. 2016 Mar 10;1(2): p.75-82. [Original in Persian with English Abstract]

[امامى سيد محمدامين. ״باستانسـنجى؛ يلى ميـان

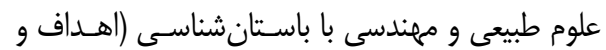

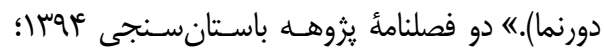

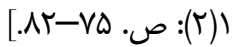

[63] Muñoz-Viñas S, Viñas SM. Contemporary theory of conservation. Routledge; 2005.

[64] Brandi C. Teoria del restauro. Ed. di storia e letteratura; 1963.

[65] Sung B.G. Identification flight over southern Iran. In Tehran 50: ein halbes Jahrhundert deutsche Archäologen in Iran; eine Ausstellung des Deutschen Archäologischen Instituts in Zusammenarbeit mit dem Museum für Islamische Kunst, by: Eurasien-Abteilung Deutsches Archäologisches Institut. Staatliche Museen Berlin;2. 12. 2011-4. 3. 2012, Translated in Persianby B, Rahimipour P. Translated by Fahimi. H. Translated by Fahimi H. Tehran: National Museum of Iran 2016. [In Persian]

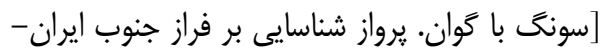

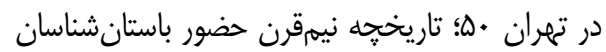

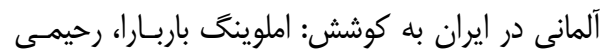

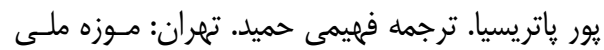

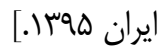

[66] Fassbinder JW. Geophysical prospection of the frontiers of the Roman Empire in southern Germany, UNESCO World Heritage Site. Archaeological Prospection. 2010 Jul;17(3): p.129-39.

[67] Telford WM, Telford WM, Geldart LP, Sheriff RE, Sheriff RE. Applied geophysics. Cambridge university press; 1990 Oct 26.

[68] Conyers LB, Goodman D. Groundpenetrating radar. An Introduction for Archaeologist: AltaMira Press; 1997 Mar; p. 149-194

[69] Daniels DJ. Ground Penetrating Radar, the institution of electrical engineers. London, UK. 2004.

[70] Linford N. The application of geophysical methods to archaeological prospection. Reports on progress in physics. 2006 Jun 26;69(7):2205.

[71] Sarlak B, Aghajani H. Archaeological investigations at Tepe HissarDamghan using Gravity and Magnetics methods. Journal of Research on Archaeometry. 2017 Mar 10;2(2): p.1934. [Original in Persian with English Abstract

$$
\begin{aligned}
& \text { [سر لكى بهزاد، آقاجانى حميد. بررسى باستانسنجى در }
\end{aligned}
$$

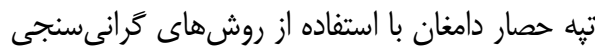

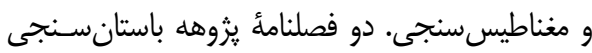

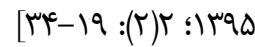

[72] Goodman D, Piro S. GPR remote sensing in archaeology. New York: Springer; 2013 Mar 19; 9: p. 233

[73] Aminpour B. Application of exploratory geophysical methods in archeology and an example of the application of magnetometric method around Choghaznabil temple.Bastan Pajhohi Journal, 1380; 4. (8) p. 4-9 .[in Persian]

$$
\begin{aligned}
& \text { [امين يور بابك. كاربرد روشهاى زئوفيزيك اكتشـافى }
\end{aligned}
$$

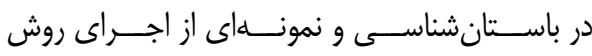

$$
\begin{aligned}
& \text { مغناطيس دنججى در اطراف معبــــ خغازنبيـل. باسـتان }
\end{aligned}
$$

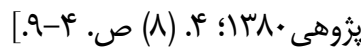

[74] AliTajer S, Afshari Azad S. Investigating the Role of Geomatics Engineering in the Applications of Cultural Heritage, Archeology and Architecture. Journal of Archaeological Researches in Iran. 2013;5: p.169-9.[Original in Persian with English Abstract]

$$
\text { [عليتاجر سعيد، افشـارى آزاد سـميه. بررسـى جايخــاه }
$$


باستان شناسى و معمارى. دوفصلنامه علمى -يثرهشى

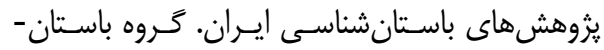
شناسى دانشكده هنر و معمارى بـوعلى سـينا. بوسا؛ [اس

[75] Luo L, Wang X, Guo H, Lasaponara R, Zong X, Masini N, Wang G, Shi P, Khatteli H, Chen F, Tariq S. Airborne and spaceborne remote sensing for archaeological and cultural heritage applications: A review of the century (1907-2017). Remote sensing of environment. 2019 Oct 1; 232:111280.

[76] Clark JG. Star Carr: a case study in bioarchaeology.1972.

[77] Clark JG. Bioarchaeology: Some extracts on the theme. Current Anthropology. 1973 Oct 1;14(4): p.464-70

[78] Buikstra JE. Biocultural dimensions of archaeological study: A regional perspective. Biocultural adaptation in prehistoric America. 1977: p.67-84

[79] Wright LE, Yoder CJ. Recent progress in bioarchaeology: approaches to the osteological paradox. Journal of Archaeological Research. 2003 Mar 1;11(1): p.43-70.

[80] Killgrove K. Bioarchaeology in the Roman world (Doctoral dissertation, University of North Carolina at Chapel Hill).2005

[81] Roberts CA. Human remains in archaeology. A handbook. Number 18 Volume 10 Issue. 2009 Jul;29.

[82] Afshar Z. Bioarchaeology: Scientific Studies of Archaeological Human Skeletal Remains. JRA. 2018; 4 (2): p.81-92. [Original in Persian with English Abstract]

$$
\begin{aligned}
& \text { [افشـار زهـــا. زيستباستانشناسـى: مطالهـه علمـى }
\end{aligned}
$$

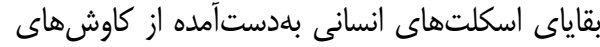

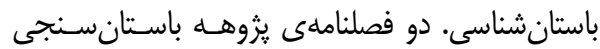

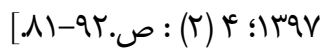

[83] Eurasien-Abteilung Deutsches Archäologisches Institut. Tehran 50: ein halbes Jahrhundert deutsche Archäologen in Iran; eine Ausstellung des Deutschen Archäologischen Instituts in Zusammenarbeit mit dem Museum für Islamische Kunst, Staatliche Museen Berlin; 2. 12. 2011-
4. 3. 2012 im Pergamonmuseum, Museumsinsel Berlin, aus Anlass des fünfzigjährigen Bestehens der Außenstelle Teheran des Deutschen Archäologischen Instituts. von Zabern; 2011. [in Persian]

$$
\begin{aligned}
& \text { [ينكه نوربرت. تحليل علمى يافتههـاى جـانورى - در }
\end{aligned}
$$

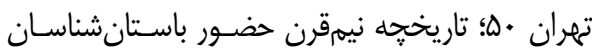

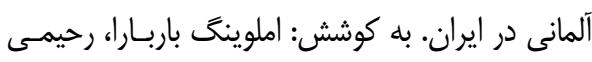

$$
\begin{aligned}
& \text { يور هاتريسيا. ترجمه فهيمى حميد. ناشـر: مـوزه ملى إنى }
\end{aligned}
$$

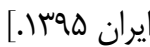

[84] Price TD, Burton JH. An introduction to archaeological chemistry. Springer Science \& Business Media; 2010 Oct 17.

[85] Brown TA, Brown K. Biomolecular archaeology: an introduction. John Wiley \& Sons; 2011 Feb 8.

[86] DeNiro MJ, Epstein S. Influence of diet on the distribution of carbon isotopes in animals. Geochimica et cosmochimica acta. 1978 May 1;42(5):495-506.

[87] DeNiro MJ, Epstein S. Influence of diet on the distribution of nitrogen isotopes in animals. Geochimica et cosmochimica acta. 1981 Mar 1;45(3):341-51.

[88] Katzenberg MA, Schwarcz HP, Knyf M, Melbye FJ. Stable isotope evidence for maize horticulture and paleodiet in southern Ontario, Canada. American Antiquity. 1995 Apr;60(2):335-50.

[89] Little EA, Schoeninger MJ. The Late Woodland diet on Nantucket Island and the problem of maize in coastal New England. American Antiquity. 1995 Apr;60(2):351-68.

[90] B. Kasiri M, Abedi A. Application of Strontium Isotope Analysis of Bone and Tooth in the Study of Ancient Immigrations. JRA. 2020; 6 (1) :17-31: DOI:10.29252/jra.6.1.17

$$
\begin{aligned}
& \text { [باقرزاده كثيرى مسعود، عابـدى اكبـر. كـاربرد آنـاليز }
\end{aligned}
$$

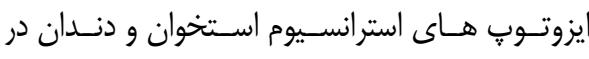

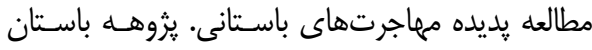

$$
\begin{aligned}
& \text { [TI-IV: (1) (1) سنجى. }
\end{aligned}
$$

[91] Emami M. The study of mineralogy and archaeometry of ceramic artifacts during 1600-700 B.C. in Haft Tappeh, 
Choghazanbil, Eighty Years of Iranian Archaeology, Vol. 2, Editors: Yousef Hassanzadehy; Sima Miri: Pazineh Press Center \& National Museum of Iran. 2012.pp314-328

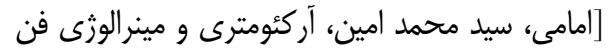

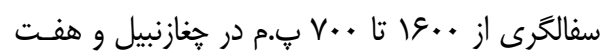

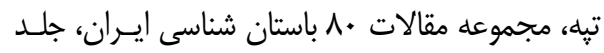

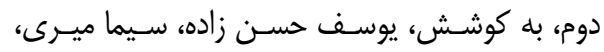

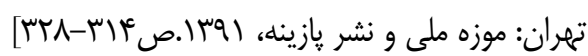

[92] Chaychi Amirkhiz A, Shaikk Baikloo Islam B. Climatic Hazards of Fourth Millennium BC and Cultural $p$ Responses of Human Societies Case Study: Tehran Plain and QomroudGharachay Basin. JRA. 2020; 6 (1) :6780 DOI: 10.29252/jra.6.1.67

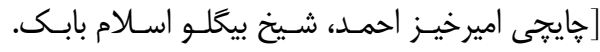

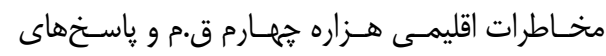

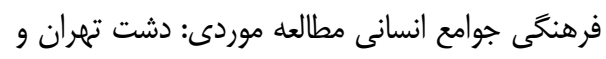

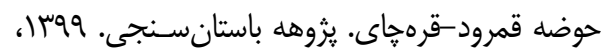

$$
[\mathrm{QV}-\Lambda \cdot:(1) \mathrm{c}
$$

[93] Levy, T.E and Liss, B (2020) Cyberarchaeology C. Smith (ed.), Encyclopedia of Global Archaeology, Springer Nature Switzerland AG 2020 https://doi.org/10.1007/978-3-31951726-1_3203-1

[94] Forte $\bar{M}$, editor. Cyber-archaeology. Oxford: Archaeopress; 2019.

[95] Liritzis I, Al-Otaibi FM, Volonakis P, Drivaliari A. Digital technologies and trends in cultural heritage. Mediterranean Archaeology \& Archaeometry. 2015 Jan 1; 15(3):31332.

[96] Mirsafdari S, Mohammadifar Y. Recreating Information in Digital Archeology. Parseh J Archaeol Stud. 2020; 4 (13): 181-192

$$
\begin{aligned}
& \text { [ميرصفدرى ش، محمدىفر. ى. بازآفرينى اطلاعـات 181: }
\end{aligned}
$$

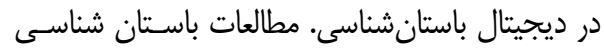

$$
\begin{aligned}
& \text { [ارسه. }
\end{aligned}
$$

[97] Elgewely E. 3D Reconstruction of Furniture Fragments from the Ancient
Town of Karanis. Studies in Digital Heritage. 2017 Dec 14;1(2):409-27.

[98] Jelodarian, B, Razani. M. Using Reflectance Transformation Imaging (RTI) to Examine Surface Morphology of Chlorite Handbags of the HalilRoud Culture Basin, Jiroft belongs to Azerbaijan Museum. 2nd International Conference on the Archaeology of Southeastern Iran at: Jiroft, IRAN. December 2017

$$
\begin{aligned}
& \text { [بهروز جلوداريـان بيـدكلى، مهـدى رازانس، بررسى }
\end{aligned}
$$

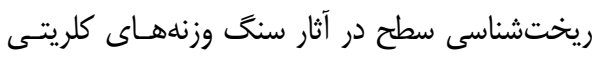

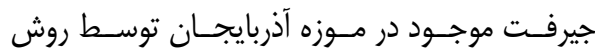

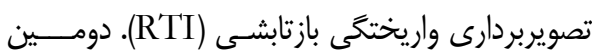

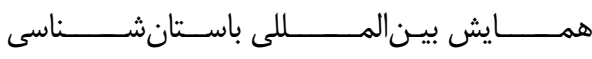

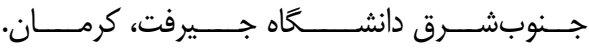

[99] Razani M, Haddadian MA. The Use of New Prototyping Technology to Reconstruct Missing Parts of the Archaeological Pottery. Pazhoheshhaye Bastan shenasi Iran. 2018 Nov 22;8(18):193-212. doi: 10.22084/nbsh.2018.15134.1670

]رازانى مهدى، حداديان محمد على، يور عباس صـفر.

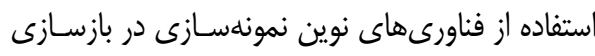

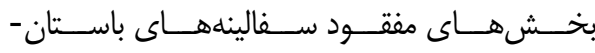

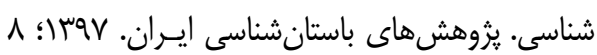

[I

[100] Razani M, Haddadian M A, porabbas S. The Use of Rapid Prototyping Technology to Reconstruct the Missing Parts of Glass Works with the Approach of Applying in Historical Glasses. mmi. 2016; 6 (12) :85-102

$$
\begin{aligned}
& \text { ]رازانى مهدى، حداديان محمد على، يورعباس صـفر. }
\end{aligned}
$$

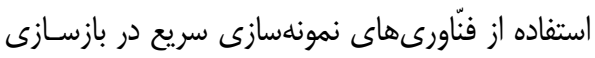

$$
\begin{aligned}
& \text { بخشهاى مفقود آثار شيشهاى با رويكـرد اسـتفاده در }
\end{aligned}
$$

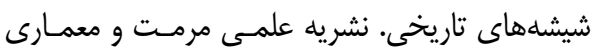

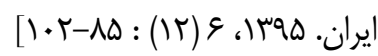

